\title{
American
}

\section{Pomological Society}

\section{A SPECIAL REPORT 1904-5}

The Cherry, Peach, Pear, Plum Small Fruits

$$
\begin{array}{r}
S B 355 \\
A 58
\end{array}
$$




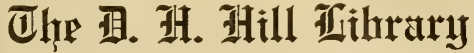

:

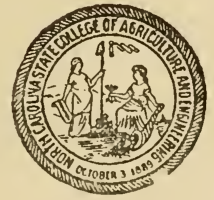

Narthl Caralina State Crallege

$$
\begin{gathered}
\text { SB3 } 55 \\
\text { A } 58
\end{gathered}
$$

This BOOK may be kept out TWO WEEKS ONLY, and is subject to a fine of FIVE CENTS a day thereafter. It is due on the day indicated below:
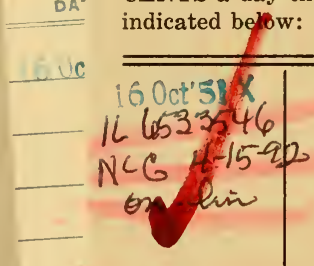


\section{THE CHERRY \\ $\int_{(}$}

TOGETHER WITH

REPORTS AND PAPERS ON PEAR, PLUM, PEACH, GRAPE, AND SMALL FRUIT

BY

COMMITTEES OF THE AMERICAN POMOLOGICAL SOCIETY

EDITED BY THE SECRETARY

$\therefore$ 



\section{CONTENTS.}

Officers and Committees $\ldots \ldots \ldots \ldots \ldots \ldots \ldots \ldots \ldots \ldots \ldots \ldots$ 6 6 -9.

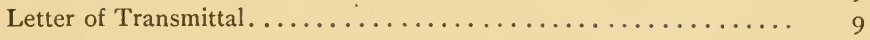

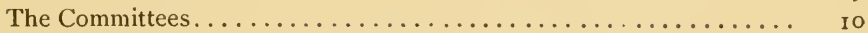

Goodman, L. A., on Missouri exhibit ............... I I

Stanton, J. W., on Illinois exhibit .............. I 2

The Cherry in North America.

Letter by Chairman Macoun .................. I 4

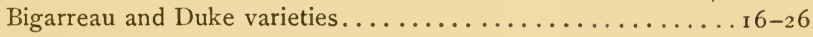

Sour cherries . ........................ 27-38

Status of the cherry in United States and Canada. . . . . . . . . . . . . . . . . . . .

Varieties recommended ...................... ${ }_{4} 6$

Cherries at Louisiana Purchase Exposition . . . . . . . . . . . 47

Cherry statistics .............................. $4^{8-50}$

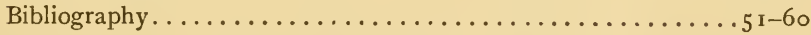

Pear Growing, present trend. Cornell, J. B ............... . $6_{\mathrm{I}-64}$

Report on Plums. Committee ...................... $6_{5}-6_{7}$

Classification of the Peach. Price, R. H...............68-7 I

Report Committee on Grapes. Munson, T. V.............. 72-77

Report of Committee on Small Fruits. Stevens, A. F . . . . . . . 77-82 



\title{
OFFICERS AND STANDING COMMITTEES
}

\section{OF THE \\ AMERICAN POMOLOGICAL SOCIETY \\ FOR}

1903--1904

\author{
PRESIDENT : \\ J. H. HALE, South Glastonbury, Conn. \\ FIRST VICE-PRESIDENT : \\ CHARLES IV. GARFIELD, GRAND RAPIDS, Mich.
}

STATE VICE-PRESIDENTS :

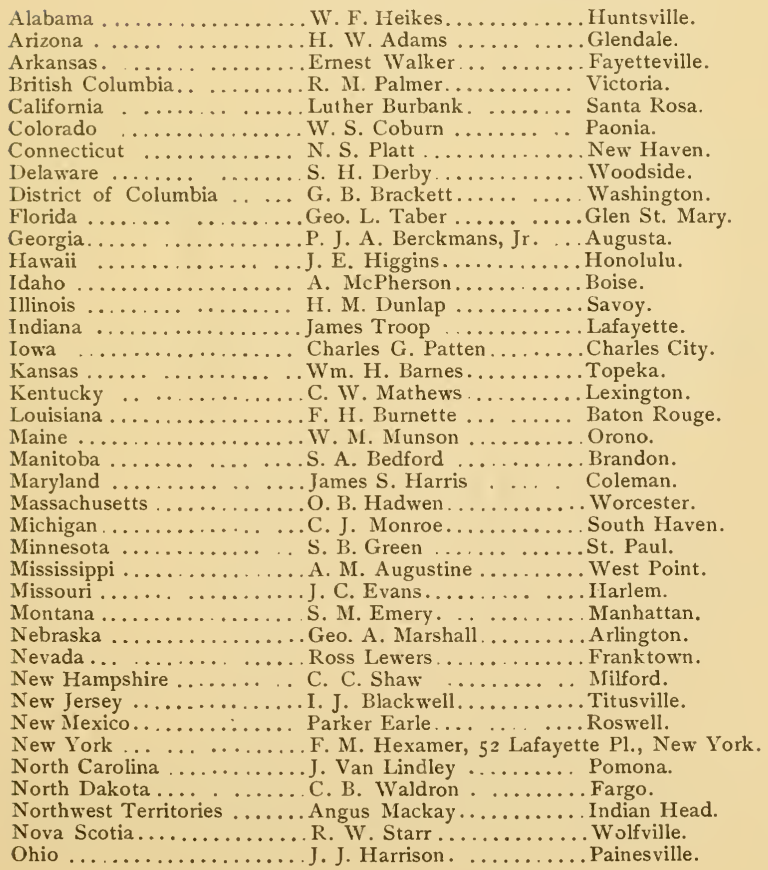


Oklahoma ................ M. Morris .......... Stillwater.

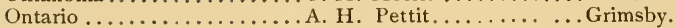

Oregon .................. L. Smith ............Hood River.

Pennsylvania ................ A. Chase, 1430 S. Penn. Sq., Philadelphia.

Prince Edward Island. ...... Rev'd Father Burke ....... Alberton.

Porto Rico ............. F. D. Gardner ............ Mayaguez.

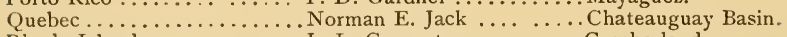

Rhode Island ............ J. L. Carpenter . ........ Cumberland.

South Carolina ............ Charles U. Shepard ....... Summerville.

South Dakota ................ C. Warner. ........ Forestburg.

Tennessee .............. John Wieland......... Knoxville.

Texas .................. T. Munson .......... Denison.

Utah $\ldots \ldots \ldots \ldots \ldots \ldots$ Thomas Judd................ St. George.

Vermont ..............Wm. Stewart ......... Burlington.

Virginia................ Samuel B. Woods....... Charlottsville.

Washington ......................... Balla Walla.

West Virginia ............. F. C. Brooks ............. French Creek.

Wisconsin ............Wm. Marshall ............ Madison.

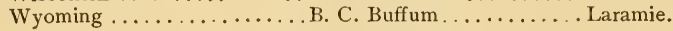

SECRETARY :

JOHN CRAIG, Ithaca, N. Y.

TREASURER :

L. R. TAFT, Agricultural College, Mich.

\section{STANDING COMMITTEES.}

\section{EXECUTIVE COMMITTE:}

C. L. Watrous $\ldots \ldots \ldots \ldots \ldots \ldots \ldots \ldots \ldots \ldots \ldots \ldots \ldots \ldots$ Des Moines, Ia.

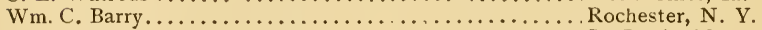

Wm. Trelease ........................................ Mo.

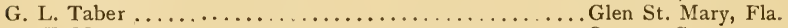

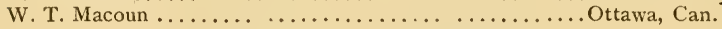

\section{FINANCE COMMITTEE :}

J. J.. Harrison . . . . . . . . . . . . . . . . . . . Painesville,

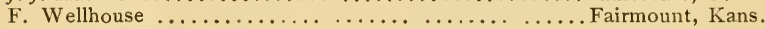

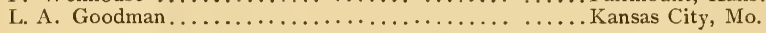

GENERAL FRUIT COMMITTEE :

Chairman, S. A. BEACH, Geneva, N. Y.

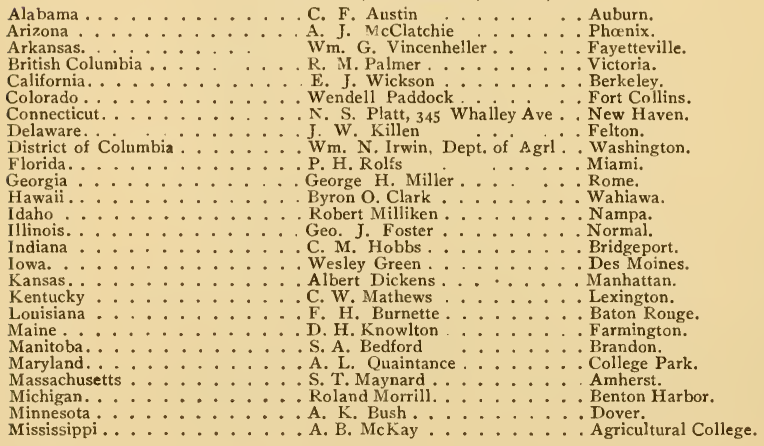




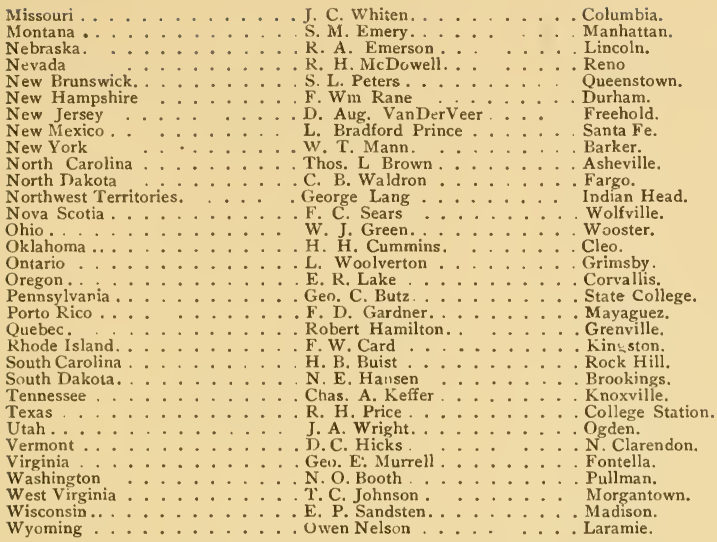

\section{COMMITTEE ON NEW FRUITS OF AMERICAN ORIGIN.}

Chairman, S. B. GRenN, St. Paul, Minn.

Districts $\mathrm{I}$ and $\mathbf{2}, \mathrm{L}$. R. Taft

Districts 3 and $4, \mathrm{Wm}$. B. Alwood

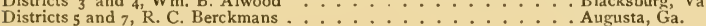

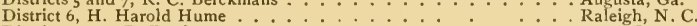

District 8, A. T. Erwin $\cdots$ Ames, Ia

Dis rict 9 , Frederic Cramfield . . . . . . . Madison. Wis.

Districts ro, 13, 14, Wendell Paddock . . . . . . . . Ft. Collins, Col.

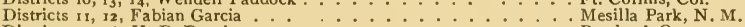

Districts 15,16 , H. E. Dosch

Districts 17, 18, E. J. Wickson . Berkeley, Cal.

District 19 , A. J. McClatchie $\ldots \ldots \ldots$ Phonix, Ariz.

\section{COMMITTEE ON FOREIGN FRUITS :}

P. J. Berckmans

Chairman, G. L. TABER, Glen St. Mary, Fla.
L. H. Bailey
D. G. Fairchild, U. S. Dept. of Agriculture
B. von Herff
F. H. Burnette . . Baton Rouge, La.

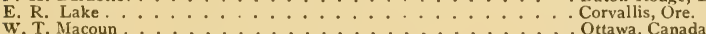
W. T Macoun . . . . . . . . . . Ottawa, Canada
W. T. Swingle, U. S. Dept. of Agriculture. . . W . . . . .

\section{COMMITTEE ON TROPICAL AND SUB-TROPICAL FRUITS :}

Byron O. Clark .

Geo. C. Roeding $\ldots \ldots$ Fresno, Cal,

Chairman, A. A. Boggs, Cocoanut Grove, Fla.

H. J. Webber, U. S. Dept. of Agriculture . . . . . . . . Washington, D. C.

C. P. Taft ...................... Orange, Cal.

Jon. J. Haden

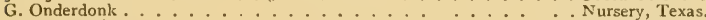

Chas. H. Shinn $\ldots \ldots$ Berkeley, Cal.

A. J. McClatchie. . . . . . Phoenix, Ariz.

H. Harold Hume.

Frank D. Gardner. . . . . . . . . . . . . . . . . . . . . . .

COMITTEE ON NOMENCLATURE :

Chairman, G. B. Brackett, U. S. Dept. of Agriculture, Washington, D. C.

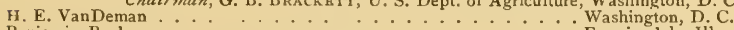
Benjamin Buckman. . . . . . . . . Farmingdale, Iil. L. R. Taft. . . . . . . . . . . . . . A Armingdale, College, Mich,

Luther Burbank . . . . . . . . . . . . . . . . .

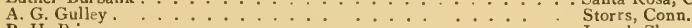
R. H. Price 
COMMITTEE ON REVISION OF CATALOGUE:

Chairman, W. H. RAGAN, U. S. Dept. of Agriculture, Washington, D. C. E. J. Wickson . . . . . . . . . . . . . Berkeley, Cal. Wendell Paddock . . . . . . . . . . . . . . Fort Collins, Col. E. L. Smith . . . . . . . . . . . Hood River, Ore. S. H. Fulton. . . . . Experiment, Ga. H. Van Deman N. S. Platt. .

SPECIAL COMMITTEE ON SCORE-CARD :

Chairman, F. A. WAUgh, Amherst, Mass.

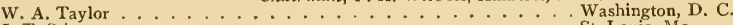
J. T. Stinson . . . . . . . . . . . . . . St. Louis, Mo. John Craig

E. S. Hubbard . . . . . . . . Federal Point, Fla.

SPECIAL COMMITTEE ON INSPECTING AND GRADING FRUIT :

Chairman, C. H. WILLIAMSON, Quincy, Ill.

F. D. Cunmings ................ Portland, Me.

W. A. McKinnon $\ldots \ldots$ Ottawa, Can.

G. Harold Powell $\ldots \ldots$ Washington, D, C.

A. A. Boggs . . . . . . . . . . . . . Cocoanut Grove, Fla.

L. A. Goodman . . . . . . . . . . . Kansas City, Mo.

\section{AD INTERIM COMMITTEE OF AWARDS.}

It accordance with the Rules adopted by th Executive Committee the following Committee was announced for the period ending with the Kansas City Meeting:

General Chairman, Dr. F. M. Hexamer, 52 Lafayette Place, New York, N. Y.

SUB-COMMITTEE ON POME FRUITS :

R. S. Northrup, Logan, Utah.

Chairman, C. W. GARFIELD, Grand Rapids, Mich.

W. T. Macoun, Ottawa, Canada.

Wm. C. Strong, Waban, Mass.
L. A. Goodman, Kansas City, Mo.

E. F. Babcock, Waitsburg, Washington.

Benjamin Buckman, Farmingdale, Ill.

\section{SUB-COMMITTEE ON GRAPES :}

Raphael Bush, Bushberg, Mo.

Geo. C. Husman, Washington, D. C.

Silas Wilson, Atlantic, Ia.
Chairman, S. A. BEACH, Geneva, N. Y.

T. V. Munson. Denison, Texas.

H. V on Luttichau, Earleton, Fla.

H. N. Starnes, Experiment, Ga.

\section{SUB-COMMITTEE ON MISCELLANEOUS AND SMALL FRUITS :}

F. W. Card, Kingston, R. I.

L. R. Taft, Agricultural College, Mich.

Chairman, W. J. GReEN, Wooster, Ohin.

A G. Gulley, Storrs, Conn.

L. Woolverton, Grimsby, Ontario.

E. L. Smith, Hood River, Oregon.

\section{SUB-COMMITTEE ON CITROUS FRUITS :}

W. H. Backus, Riverside, Cal.

H. Harold Hume, Raleigh, N. C

N. W. B lanchatd, Santa Paula, Cal.

\section{Chairman, G. L. TABer, Glen St. Mary, Fla.} Chas. H. Shinn, Niles, Cal. E. L. Koethen, Riverside, Cal. W. S. Hart, Hawks Park, Fla.

\section{SUB-COMMITTEE ON TROPICAL AND SUB-TROPICAL FRUITS :}

Chairman, E. J. WICkson, Berkeley, Cal.

A.A.Boggs, Waynesboro, N.C., or CocoanutGrove, Fla.G. Onderdonk, Nursery, Texas.

Ellwood Cooper, S inta Barbara, Cal. A. J. McClatchie, Phøinix, Ariz. P. H. Rolfs, Miami, Fla.

F. H. Burnette, Baton Rouge, La.

\section{SUB-COMMITTEE ON NUTS :}

B. M. Young, Morgan City, Ia.

J. W. Killen, Felton, Del.

N. S. Platt, Cheshire, Conn.
Chairman, H. E. VAN DEMAN, Washington, D. C

Henry E. Dosch, Hillsdale, Oregon.

J. Russel Smith, Lincoln, Va.

Felix Gillet, Nevada City, Cal 


\section{SPECIAL REPORT OF THE AMERICAN POMOLOGICAL SOCIETY}

\section{A STUDY OF THE CHERRY}

WITH NOTES ON CERTAIN OTHER CLASSES OF FRUITS

It was first proposed to call a meeting of the American Pomological Society for the express purpose of taking advantage of the peculiar opportunities afforded by the Louisiana Purchase Exposition in 1904 for a study of fruits in relation to influence of soil, latitude and location. A canvas of our members showed that the great majority were in favor of dispensing with the meeting and having the work done by committees. To this end competent committees were appointed to take up the study of the leading classes of fruits. Some of the committees attacked their tasks systematically and with a spirit of thoroughness. Others were prevented by various causes. The reports of these committees, together with additional papers constitute this report.

Among the topics which it was intended to present were monographs of groups or types of fruit ; promising varieties of apples, pears, peaches, plums, and the like ; quality of fruit as influenced by cold storage ; quality as influenced by elevation; appearance influenced by altitude; the ideal home of the Ben Davis; the ideal home of Spy ; where should we grow Elberta, and many of similar character. Many of these have been omitted.

We regret particularly the omission of the report by the committee on apples. The chairman of that committee has found it impossible up to this time to collate and edit the large amount of data collected. It is hoped that this will be forthcoming later and that we may therefore present it in a subsequent volume of the proceedings.

One of the important parts of this report is the contribution to cherry literature given us by the committee on that fruit. This is really a monograph of the subject and will undoubtedly prove of great value to pomologists and teachers. It is a type of effort we hope to continue.

John Craig,

Secretary.

Ithaca, N. Y.,

July 10, 1905 . 


\section{THE COMMITTEES}

We are greatly indebted to Frederick W. Taylor, Chief of Agriculture and Horticulture, of the Louisiana Purchase exposition for his hearty coöperation in furthering the work of the committees. This was done by including among the Exposition jurors a large number of the members of the society's committeemen. The work of the juror furnished invaluable opportunity for the collection of important data. The personnel of the committees was carefully considered so that each group of men may be looked upon as experts in the particular field which they represent.

\section{Committee in Charge of Report}

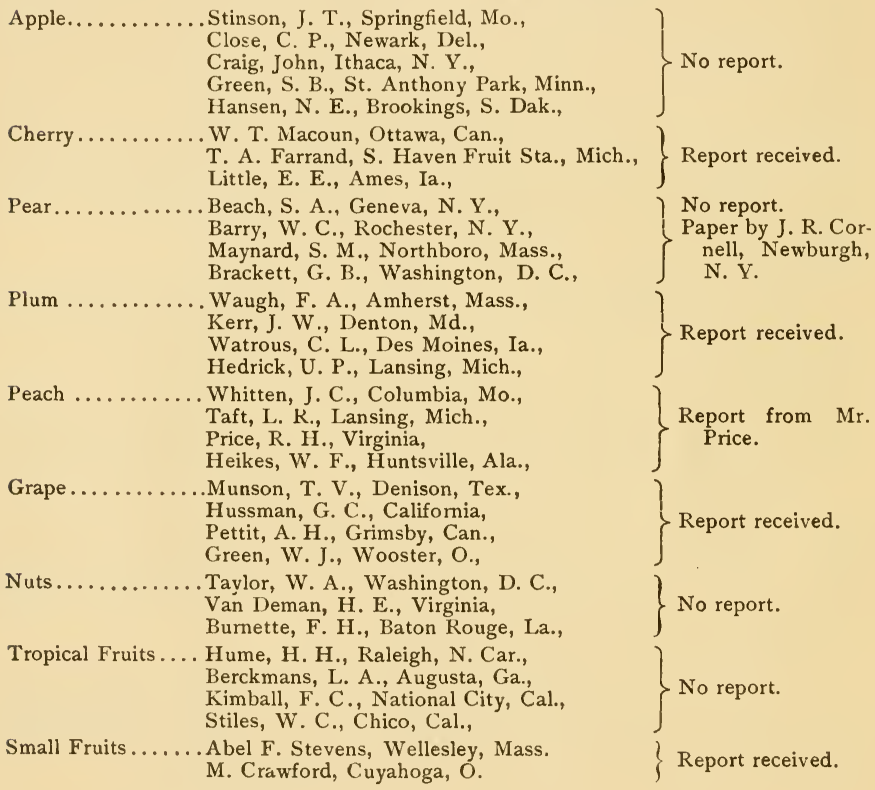




\section{NOTES ON THE APPLE GATHERED FROM THE MISSOURI EXHIBIT}

\section{A. Goodman}

The gathering, keeping and exhibiting of Missouri Fruits was a study, a lesson, a work, an experiment. Not being sure of some of the results, or of the plans of procedure in keeping the apples, it required all of the different lines of experiment to make a success of the keeping. We began the work, therefore, of collecting apples for cold storage on Sept. I oth, and finished on Nov. Ist, 1903. Putting into storage some varieties which we supposed would not hold over, we were agreeably surprised to find that they came out of storage in May and June in very good condition indeed. These were such varieties as Ortley, Lowell and Wolf River. All of this fruit was gathered when in the best of condition, that is ripe, well colored, firm and as near perfect as we could find it. The specimens were at once wrapped in tissue paper and then in wax paper packed closely in boxes, or barrels and sent at once by express to the cold storage, and there placed in a temperature of $3 \mathrm{I}$ to 32 degrees, and held at this temperature during the whole of the season.

I am sure if this plan is followed we can keep apples without loss. Of course it would not be possible in a commercial way to follow this plan because of the expense, but the nearer we can approximate this plan the more perfectly the apples will keep. We exhibited, for instance the Gano apple three years, two years and one year, so that we had on the tables during the month of November, 1904, plates of Gano apples of 1901, 1902, 1903 and 1904 . As a result of our plan of gathering and handling we also kept Flora Bell, Ortley and Lowell until June first ; Maiden Blush and Wealthy until July first; Jeffries, Wolf River and Grimes Golden until August; Huntsman, York, Winesap, Rome Beauty, Black Twig and others of that class held until September and October in splendid condition, except that they were scalded somewhat. After these dates, although we had these varieties on the tables much longer, yet they showed the damage done by scald while in cold storage.

The length of time the apples kept on the tables depended upon the character of the flesh of the apples as well as the condition of the fruit at gathering time. It is not so much the keeping qualities of the apple while in cold storage, although that is also an item in their favor, but it is the consistency, firmness, character of the flesh, the inherent qualities of the apple itself. Apples like Ingram, Clayton, Lawver, Willow Twig, Gano, Ben Davis, Jonathan, Nickajack, Early Pennock, Flora Bell, Maiden Blush and Lady Sweet will hold from one week to one month after being put upon the tables, and hold in good condition, no matter what the 
weather may be; while such varieties as Wolf River, Smith's Cider, Huntsman, and even York, Winesap and Black Twig will not hold up long in good color and condition after coming out of cold storage.

The best plans of cold storage and the best varieties for that purpose have not as yet, by any means been thoroughly established. We have still many things to learn as to the individuality of each variety. Other apples, seemingly just as good in flesh, and just as good keepers will not hold up after being taken from cold storage anything like as well, and in fact go to pieces in a few days, or a week at most, or at least deteriorate so badly in appearance that they are not fit to show or sell. I feel sure that we must look to the keeping qualities of our apples both in and out of cold storage in all our future plantings, and this matter can be settled only by experiments in testing them.

This then should be the order of our requirements in selecting our apple varieties for future planting: Hardiness, Productiveness, Resistance to Fungus Diseases, Cold Storage Adaptation, Quality, Size and Color.

The apple display at the World's Fair was a great lesson to every one who saw it, and it is to be regretted that some one was not appointed to make a record of the apples shown by every State, of the time at which they were put on the tables, the keeping qualities, and the length of time they kept in good condition. Such a record of every day's work from the opening ta the closing of the Exposition, and from every State would be of untold value to all our fruit growers. As it now is I have tried to keep in a general way only, a list of the best and the poorest keepers, after being in cold storage and my conclusions are given as herein stated.

\section{NOTES ON THE KEEPING OF APPLES IN THE ILLINOIS EXHIBIT}

\section{J. W. Stanton}

On account of the almost total failure of the apple crop in Illinois in I 903 we had only few varieties in storage for the exhibit, among them being Ben Davis, Willow Twig, Grimes Golden, Jonathan, Rome Beauty, Wine Sap, Gano, Winter May, (known also as May of Myers and Ranish May) Janet, Kinnird's Choice, Mam. Black Twig, Ark. Black, York Imperial, Huntsman, Salome, Yellow Belleflower, Roman Stem, Lawver, and Minkler. These were allowed to mature and color on the trees, when they were carefully picked and wrapped with two coverings of paper, tissue next to apple and parchment on outside. They were sent at once to storage. In placing them on exhibit I took out the early maturing sorts first : Grimes and Jonathan and York Imperial, on May ist, I904. Very little decay or discoloration was noticed at this time but two months later York and 
Grimes began to show "scald." Wine Sap made the best record for keeping and was in perfect condition up to Nov. ist. It was followed by the Willow Twig, Ben Davis and Gano. York and Huntsman are poor cold storage apples in my experience at four expositions. They do not stand up and scald before the early winter market period. About July ist the Grimes began to come out of storage showing some scald which increased up to about Aug. 1 $5^{\text {th }}$ when the supply was exhausted.

I exhibited Jonathan of 1903 and 1904 at the same time also Ben Davis, Willow and Winesap. I put up apples for the exhibits of Illinois at Omaha, Buffalo, Charleston and St. Louis and have had charge of these exhibits. From my observation and experience I am of the opinion that the keeping of any apple depends largely on the proper maturing ; the handling from the tree to storage; also it is important that the temperature be kept uniform and that packages be not moved or transferred from one part of storage to another as is sometimes done by storage people. Wrapping with paper prevents scalding, that is to say apples not wrapped like York and Huntsman will show scald in 30 or 60 days while those wrapped will come out in good shape much later. Red varieties such as Jonathan last much longer. 


\title{
THE CHERRY IN NORTH AMERICA
}

\author{
PREPARED BY THE COMMITTEE ON CHERRIES APPOINTED \\ BY THE AMERICAN POMOLOGICAL SOCIETY
}

Committee-W. T. Macoun (Chairman), E. E. Little, T. A. Farrand

The Cherry is the most neglected of all the important fruits which succeed in the United States and Canada ; among the principal causes of neglect are the tenderness of the fruit making it difficult to market or transport long distances; the depredations of birds which devour so much of the fruit that there is little left for marketing unless the orchards are large; the diseases and insect pests which owing to the fact that there are comparatively few large commercial orchards, have not received the same attention as those affecting other fruits, such as the apple, pear, plum and peach. The cherry is a delicious and refreshing fruit and should be much more widely planted than it is at present. It is always in demand and the market is rarely glutted. There is no doubt that if cherries were sold at reasonable prices they would be as popular to eat out of hand as they are in Europe, where the people use them very freely in the fresh condition. Canned and preserved cherries in most towns and cities are considered a great treat at the present time, owing to the prohibitive prices which have to be paid for the fruit. As there have been comparatively few new varieties of cherries of merit originated during recent years, it was thought best by this committee to devote the space allotted to cherries to a general discussion and fairly exhaustive treatment of this fruit, so that when there is a revival of interest in cherry culture, as is sure to take place at no distant date, there will be in this report a mass of useful information for the intending planter.

This report has been divided into three parts, each of which has been prepared by a member of this Committee.

Part I, by T. A. Farrand, Director, South Haven Fruit Station, Michigan. This includes recommendations for propagating the cherry ; for locating and planting the orchard; for pruning, cultivation, cover crops, fertilizing; for the prevention and destruction of injurious insects and diseases. There is also a descriptive list of the most popular varieties of Bigarreau and Duke cherries, and of a few new varieties. Harvesting, packing and marketing the fruit are also dealt with in Part I.

Part II, by E. E. Little, Assistant in Horticulture at the Iowa Experiment Station, Ames, Ia. This treats of the introduction and development. of the sour cherries in America, especial attention being drawn to the Rus- 
sian varieties. Notes on propagation and methods of planting for cold climates are here given. The sour cherries are divided into four distinct groups, each of which is described. A large number of varieties are described, and the promising ones specially noted.

Part III, by W. T. Macoun, Horticulturist, Central Experimental Farm Ottawa, Canada. This is, for the most part, historical and statistical. A list of the varieties of cherries recommended by the American Pomological Society for the various fruit districts in the United States and Canada is given, also cherry statistics from the latest Census Reports of the United States and Canada. There are also extracts from letters of prominent Horticulturists in the United States and Canada in answer to questions relating to cherry culture in the States which they represent. Information is given regarding cherries at the recent Louisiana Purchase Exposition at St. Louis. This part of the report ends with a bibliography of cherries.

I wish to take this opportunity of acknowledging the enthusiastic coöperation and aid of the other members of this Committee.

W. T. MACOUN,

Ottawa, Canada.

Chairman, Committee on Cherry. 


\section{PART I}

\section{BIGARREAU AND DUKE VARIETIES: PRUNUS AVIUM}

\section{Culture, Varieties and Marketing}

\section{General Notes}

The Bigarreau and Duke Cherries, like a large percentage of the choicest in quality of all kinds of fruit, lack hardiness and are usually more subject to the ravages of insects, pests and disease, but it is chiefly on account of lack of hardiness that the sweet cherry is not planted more commercially than it is at present in Central and Eastern United States and Canada; California and the Pacific Coast States leading in the production of the sweet cherry. The very strong tendency of the birds to appropriate their share and, "sometimes a little more," of this product, is also given as a reason for not planting more largely for home use as well as market.

The sour cherry is considered the most profitable by most of the Michigan growers, there being only an occasional year, when the sweet proves an exception to this rule.

Sixty-five per cent of all the Cherries grown in Michigan are in the counties bordering on Lake Michigan, the estimate as to acreage being one of sweet, to ten of sour.

Prof. E. J. Wickson, Horticulturist, Berkley, Cal., reports that the Duke Cherries are practically absent from California fruit growing, that there are a few trees scattered here and there but are of no commercial value, and are never seen on their markets, the sweet cherry being used exclusively for table use, as well as cooking purposes. "The same is practically true of Western Oregon." In the interior east of the Sierra Nevada mountains, the Dukes are more widely planted than the Bigarreau, because they are more hardy and less injured by the alternation of heat and cold during the winter season.

Prof. H. N. Starnes, Horticulturist Experiment, Georgia, reports the Bigarreau and the Dukes succeed only in Northwest Georgia, and in the mountains of North and Northeast Georgia, and that the plantings are of no commercial importance.

Prof. E. E. Little, Ames, Iowa, states that the growing of the sweet cherry in Iowa is considered of little value, that possibly in the Southeast part of the state one or two of the more hardy varieties might succeed.

Prof. A. G. Gulley, Storrs, Conn.: There are very few sweet cherry trees planted here now. The older trees scattered around do well, but young trees fail. Out of a dozen varieties planted ten years ago, one, 
"Windsor," has matured fruit and that only one crop, and Mr. Gulley states, he would not think of planting them for profit.

Prof. John Craig, Horticulturist, Ithaca, New York, states that there are very few orchards in the state of purely Mazzard varieties, but that trees of this kind can be found on nearly every homestead in the peach growing sections of the state, and are more largely planted in the Hudson River regions and along the Niagara River. The comparatively large orchards on Long Island have fallen by the way. He estimates that the proportion acreage for State as ten per cent sweet.

\section{Propagation}

The Sweet Cherry is propagated almost exclusively by budding on the yearling stocks of its hardy ancestral type, the "Mazzard stock," and by budding upon the Mahaleb stock, a hardy type, of the sour cherry which is used exclusively for budding the sour kinds. The Mazzard stock is used to propagate the sweet cherry almost exclusively in the Pacific Coast region, while the Mahaleb stock is used more and more by eastern nurserymen.

Under date of Nov. 28th, the following letter was received from Mr. H. L. Bird, Sec. West Michigan Nurseries, Benton Harbor, Mich. "Regarding the propagation of the sweet cherries, we would say that we always bud both our sweet and sour kinds on Mahaleb stock. Our reason for doing this is, we get much better stands on Mahaleb stock than we do on the Mazzard stock. We really think the Mazzard stock is better for the sweet kinds, on this kind of stock, were it not for the fact that it is subject to the rust, and it is hard to get our buds to take in it successfully. It is largely for the reason that it is possible to get so much better stand of buds that the Mahaleb stock is used. We nearly always get a better stand of sour then we do of the sweet varieties."

The above statements clearly define the reason and extent to which the different stocks are used in the propagation of the Cherry.

\section{LOCATION AND SOIL}

Under the above heading my observations on the cherry industry in Michigan would bear me out in stating, that location is by far the most important. In a measure we can make the soil, but location we cannot, and it is best to first look to location, and study and add to the requirements of the soil afterwards. There is no other kind of hardy fruit grown, that is so sensitive to injury by frost and cold rains, while in bloom as is the Cherry, and especially the sweet kinds, therefore the ideal location would be a high elevation rolling enough for natural drainage, with a deep gravelly sandy loam soil, and if the subsoil be clay it should be of a porous nature, not hard and solid. 
There are, however, exceptions to most all rules, and instances can be pointed out where the sweet cherry has been known to do better upon the heavier, than upon the lighter soils. The variety, Windsor, does especially well upon clay soil, but as to elevation there is no second choice, if you would be successful with the sweet cherry.

\section{Planting the Orchard}

Most varieties of sweet cherries are strong, vigorous growers, and require more room than the sour kinds, and should be planted at least 30 feet apart each way. The ground should be plowed deep and should be well harrowed, and the planting be done as soon in the spring as this can be done. All bruised portions of the roots should be cut off and a good average depth for setting the tree would be ten to twelve inches, "good judgment being the rule."

\section{PRUNING}

One of the most important points in starting a cherry orchard is the low heading of the trees. To have the lower branches start eighteen to twenty-four inches from the ground, is none too low. The low heading protects the trunk of the tree from sun scald, and the cracking of the bark, and this insures a longer life to the tree, and facilitates all of the work in caring for the tree, and picking the fruit. With the modern extension tools, the cultivation can be given under the lower limbs of the low headed trees, without inconveniences or serious injury to the tree.

The low heading of the trees, however, cannot always be regulated, as many times, the trees are high headed beyond repair, when they come from the nursery, but when it is possible head them down, and force the growth out below. The pruning should always be done in the spring, just before, or about the time the sap begins to flow.

With the strong vigorous growth of the sweet cherry, the pruning should be rather severe the first four or five years, starting the tree with from four to five main branches, and heading in, at least one half or twothirds of the new growth each year, making the foundation of the main branches strong and stocky, forming a round headed tree, with plenty of lateral branches, rather than allow the tree to grow long with no lateral branches, as is characteristic of this type.

After the trees get well into bearing the growth will be much lighter and little pruning will be necessary, except to keep dead or broken branches cut out, and thinning out to give sufficient light and air to the lower limbs. When it is necessary to cut off a large limb, the wound should be covered with grafting wax, or paint to keep the wood from drying out, while nature is healing it over, otherwise the wood would decay to the heart, would never heal over, and the tree would break down years before it otherwise would have done. 


\section{Cultivation}

A cultivated crop, such as corn, potatoes or beans can do no harm between the trees during the first three or four years, or until the trees come into bearing, providing the fertility of the soil is kept up, sowing a cover crop with the last cultivation, using oats, barley, clover, or whatever in the judgment of the grower would seem advisable. Cultivation is considered superior to any form of mulching, except dust mulch, especially in a dry season. Shallow plowing in May and thorough harrowing every week or ten days, until middle of July or August ist is considered good cultivation by our growers; using Acme, springtooth, or spike tooth harrows, or cutaway disc harrow. Care should be taken to stop cultivation soon enough to give the wood ample time to ripen up for winter, the conditions of the weather regulating the time of stopping the cultivation to some extent.

\section{Cover Crops}

The sowing of a cover crop for winter has become a universal practice by the best fruit growers. Crimson Clover is probably more largely used than any other kind of plant. Oats and barley are used in connection with the clovers or alone. Mammoth clover has proved even superior to Crimson, in some tests carried on at the South Haven Experiment Station, Michigan. Oats or barley are preferred, used with the clovers rather than either one alone. The oats and barley grow much taller in the fall and form a protection to the clover, catch and hold the snow and thus serve to better advantage ; these die down during the winter, but the clover is there in the spring, and by the middle of May, has made a good growth and by plowing it under we add a large amount of plant food, and vegetable matter to the soil.

Other leguminous plants are used, such as cow-pea, soy bean, hairy vetch, or winter vetch and field peas. Experiments have proved the cowpea to be practically worthless for cover crop purposes in Michigan, the time being too short for satisfactory growth from Aug. Ist to the last of September, when the frosts come and after the first frost, there is nothing left but the stems. The hairy vetch has given excellent results, but for cover crop purposes, the seed comes so high as to make the use of it prohibitive.

If the clovers are sown alone, eight quarts per acre is used, and if sowing the oats or barley separately, two bushels are usually used per acre, but if the oats or barley are used with the clover, one bushel of oats or barley to six quarts of clover makes an excellent combination.

If vetch is used, one bushel to the acre is none too heavy a seeding, as the seed is quite large. 


\section{Fertilizing the ORChard}

While nearly all agree as to the texture of the soil best suited to the cherry, the mineral and available elements vary so greatly in different sections, that the following statements are confined to observations and existing conditions in Michigan. Stable manure is a commodity hard to get in many sections where a large percentage of the land is planted to orchards, for this reason many growers resort to green manuring to furnish the necessary amount of nitrogen, and buy commercial fertilizers to supply the potash and phosphoric acid. For the potash a few buy hard wood ashes and use them at the rate of from 50 to roo bushels per acre, but the ashes are not always available and then muriate of potash is used at the rate of from three to five hundred pounds per acre, with from two to four hundred pounds of ground bone per acre. When it is advisable to use a complete fertilizer it is used at the rate of $2-8-10$. However, in the use of fertilizers a study of the soil with close observation on the growth and behavior of the trees is essential to wisely apply that which is most needed.

\section{INSECTS AND DISEASES}

The injurious insects and fungus diseases that attack the cherry are important factors to be met and dealt with ; only the more important are mentioned with remedies for the same. Where it is possible the insecticide and fungicide are combined thus making one spraying answer both purposes. The more important insects are Curculio, Black Aphis, and a number of the scale insects: San Jose, Aspidiotos perniciosus, and European fruit scale, Aspidiotus ostreaformis, being the more important of the latter. The Curculio is the Plum curculio, which attacks, stings, and causes the grub in nearly all of the stone fruits, and attacks the sweet cherry in preference to the sour. This insect may be checked by use of paris green or any of the arsenites combined with bordeaux mixture, when spraying for fungi. The sweet cherry ripens so soon after blossoming that the applications should follow very closely. Arsenite of lime is used with bordeaux mixture, giving one application just before blossoms open, one just as soon as blossoms have fallen and the third a week later. Usually this is all that is safe to use on account of the ripening of the fruit and all that is necessary to control this insect.

The cherry tree plant louse, Myzus cerasi, is a black shiny louse that is much more troublesome some years than others, and works on the new growth and tender foliage, making its appearance about the time the fruit is about half grown, or beginning to ripen. It secretes a sticky subtance upon the foliage twigs and fruits, which destroys the sale of the fruit, and is one of the hardest insects to control.

It is a sucking insect and must be killed by contact insecticides. The remedies recommended are kerosene emulsion with whale oil soap or tobac- 
co water, as strong as can be applied without injury to the foliage. With kerosene emulsion one of oil, to nine of water, is about as strong as can be used. The best success has been obtained with strong tobacco water, using two bushels of refuse stems from factory, soaking them 24 hours in from fifty to sixty gallons of water and applying it soon after the first appearance of the lice, and before they have time to curl up the leaves, and form a protection for themselves.

In controlling the scale insects, lime sulphur and salt, or California wash as it is called is used, which must be applied while the trees are dormant, or before the foliage comes, seeing that every portion of the bark is covered, as the lice are under the scale, and have to be killed by contact. While scale insects have not proved as destructive upon the sweet cherry as upon other kinds of fruit trees in Michigan, too much care cannot be taken in destroying them.

\section{Diseases}

The more important diseases are Black Knot, Plowrightia morbosa, Brown Rot, formerly known as Monilia, later scientifically, Sclerotina fructigena and the shot hole fungus, Cylindrosporium.

Black Knot is a parasitic fungus and causes black irregular knotty growths on the branches and the only satisfactory remedy for this is cutting out and burning.

Brown Rot is the most serious disease to contend with in the growing of sweet cherries. It can be controlled to a large extent with three applications of Bordeaux mixture, if the weather conditions are such that the cherries do not crack open at the time of ripening. Hot, moist atmospheric conditions two or three days before picking time will start them cracking, and a large percentage of the crop is likely to be destroyed by the rot.

The 4-5-50 formula, Bordeaux mixture, has been found the most satisfactory, as the foliage of the sweet cherry is more tender than the sour.

For shot hole fungus, the necessary sprayings for Brown Rot, with one application after fruit is harvested, will quite effectively control this disease.

\section{Most Popular Market Varieties}

This topic will always remain one of the most interesting in the culture of all kinds of fruit. There is an ever increasing tendency to improve, to hope against hope, that now we have the variety that has all of the good characteristics with the undesirable ones eliminated. Hundreds of varieties come up, are weighed in the balance, are found wanting and go down to oblivion, many of which would prove valuable if we knew their adaptability to regions, soils, etc. There is an occasional variety, however, that stands out and gains a popular national reputation. 
Varieties that do well in our locality, may not do so well in another section. It is an interesting fact that from a large source of information east of the Mississippi River, the variety Windsor, stands out as the most popular all around sweet cherry, with Napoleon, Black Tartarian, Yellow Spanish, Rockport, and Gov. Wood following in the order named.

With this in view, it may be said that in the above named varieties the eastern growers have a safe basis for commercial planting. For the Pacific coast region Napoleon, and Black Tartarian are always mentioned, but with a larger list of newer varieties, that are not much planted in the east. With such information as it has been possible to obtain, the following varieties may be named for the region: Black Tartarian, Napoleon, Windsor, Yellow Spanish, Rockport, Early Purple, Elton, Bing, Lambert, Centennial, and Republican. It has not been possible to get a description of a number of these varieties.

At the South Haven Experiment Station, Michigan, there are sixty varieties of Bigarreaux and Dukes, that have been well treated for a number of years and out of this number, the following have given by far the best satisfaction, Bigarreaux: Windsor, Napoleon, Yellow Spanish; Dukes : Carnation, Magnifique, and Montreuil. Many other varieties have done fairly well, and are worthy of recommendation based on reports from other sections, and their names will appear in the descriptive lists.

\section{Description of Varieties}

Bing: Originated in Oregon and introduced by Seth Lewelling of Milwaukee, Oregon. Very large; roundish heart shaped; almost black; flesh firm, meaty; flavor vinous, sweet; high quality; season medium. A most promising variety. (Description made by Van Deman.)

Centennial: Said to be a seedling of Napoleon. Yellow Spanish type of flesh. Promising.

Cleveland: Tree a very strong, vigorous, spreading grower, and productive. Fruit, medium to large, form compressed slightly heart shaped; color, light yellow shaded, with red on one side ; flesh light, quite firm, juicy, quality fair, mid-season.

Elton: Tree a good grower, but lacks productiveness here. Fruit very large, compressed elongated, heart shaped. Skin pale yellow, blushed with red, flesh light medium, firm juicy, with a sweet, rich vinous flavor, quality best, mid-season.

Kirtland, (Mary): Quite an old variety, which seems to be but little planted. Tree only moderately vigorous, but very productive. Fruit large, roundish, heart shaped. Skin, handsomely mottled, light and dark red, on yellow ground, light fleshed, very firm, juicy, early to mid-season, fine quality, weak point ; lack of vigor.

Lambert: Originated with J. H. Lambert of Portland, Oregon, on his fruit farm at Milwaukee, Oregon. Fruit large to very large, obtusely heart shaped, sutured side compressed, suture a mere line; ground color dark amber becoming covered at maturity with a beautiful dark, rich magenta, 
the ground color showing mottled; flesh dark, rich, firm and juicy with a sprightly flavor. Stem $1 \mathrm{I} / 2$ inches, stout and attached in a shallow narrow cavity. Pit small for so large a fruit. (Description made by Prof. E. W. Lake.)

Napoleon: One of the most popular varieties for all sections. The trees are strong vigorous growers, and very productive. Fruit is of large size, handsomely mottled, light and dark, with very firm light colored flesh, and good quality; mid-season.

Rockport: Highly recommended from many sections, both east and west. Tree moderately vigorous, but productive. Fruit of large size, good quality and appearance; form, roundish, compressed, heart shaped; skin, yellow with dark red blush; flesh, light, tender and juicy. Quality very good, early to mid-season.

Tartarian, Black: One of the oldest, and is at present one of the most popular market varieties in the more favorable localities. Lacks the vigor and hardiness of the Napoleon and Windsor as grown here. Fruit very large, dark red skin, and flesh with fine quality; and brings the highest market price.

Windsor: Origin, Windsor, Ont. Canada. This is one of the newer varieties that has gained a National reputation, and it is safe to say, should be included in every sweet cherry list. The trees are hardy, vigorous, and very productive. Fruit, large roundish, heart shaped; skin, dark liver colored ; flesh, dark red very firm, juicy, fine quality, medium late.

Wood: Recommended from nearly all sections for near-by markets and home use. Tree, strong, vigorous grower, very productive. Fruit, medium to large, heart shaped; skin, pale yellow, with pale red blush; flesh, white, very tender, juicy, with sweet, mild pleasant flavor; good quality ; season early. Inclined to rot badly.

Spanish, Yellow: This old well known variety does well under varied conditions, and for this reason it still holds a popular place on the lists. The trees are strong growers and very productive. Fruit, large size and good quality; medium late.

\section{Dukes}

One of the chief characteristics of this type of cherry is that it ripens its fruit over a long season, there being but few exceptions to this rule, and it is an undesirable point commercially.

In growth of tree, they vary from decidedly upright, to a round, spreading head. Botanically, this type is classed with the sweet cherries, but in flavor the fruit is neither sweet nor sour, rather half-way between. Usually, tender, juicy, with a rich sub-acid flavor, excellent, both as a fresh fruit and for making a very choice preserve.

In point of acreage, reports would indicate, that the Dukes are farless planted than either Bigarreaux or Morellos. Cherries of this type are inclined to rot and do not bear shipping well.

The more popular market varieties for all sections are May Duke, Eugenie, Olivet, Louis Phillipi, and Magnifique. The varieties, Hortense, 
Choicy, Late Duke, and Royal Duke are reported as shy bearers from most sections. All, or nearly all of the above varieties are at the South Haven station, and a number of others, among which is variety, Montrueil, which has given the best satisfaction of any Duke on trial.

\section{Description OF VARIETIES}

Carnation: "As named." Origin, unknown. Tree vigorous, upright, spreading grower, forming rather roundish head. Fruit, large roundish slightly heart shaped; stems, variable, mostly long slender ; color, very dark red ; flesh and juice, dark red; medium firm, juicy, with a rich subacid flavor, quality best ; quite productive, mid-season ; ripens over a long period. (This has well marked characteristics of the Morello. Secy.)

Eugenie: Tree upright, but lacks vigor, quite productive. Fruit of large size, oblate, compressed, inclining to heart shape; stem, medium, length stout ; flesh and juice dark red, texture very tender and juicy, subacid fine. One of the earliest to ripen, lasts over a long season.

Phillippe, Louis : From Downing. "Tree upright, spreading. Fruit, large roundish, regular stem, rather short, stout. Skin, rich dark, dark red flesh, red tender juicy sub-acid; quality very good; season, medium to late; said to be productive.",

Magnifique: One of the latest of any kind of cherry to ripen and valued particularly for this feature. Tree an upright spreading grower, forming a $U$ shaped top. Very productive of fruit of large size, and good quality, but rather too light a shade of red to take well on the market; form, roundish, inclining to heart shape; flesh, pale yellow, firm, juicy, with sprightly sub-acid flavor.

May Duke: This is one of the most popular of all the Dukes in all sections. The trees are decidedly upright, close vigorous growers, and very productive. It is one of the earliest to ripen, and as is the case with Eugenie, the leaves are large, long, and sometimes wholly hide the fruit, which is large, roundish, oblate, dark red; flesh and juice, red, tender, juicy, rich sub-acid; quality best; ripens over a long season.

Montreuil, Belle de: Trees were received from Stark Bros. in I 89 I. The variety seems to be but little known, and is worthy of a wide dissemination. It has proved to be the most productive and profitable variety of this type, on trial at the South Haven Station. The trees are healthy, vigorous, upright, spreading growers. Fruit, large heart shaped; stems, long, slender; skin, dark glossy red, almost black ; flesh and juice, dark red, medium firm juice, with a rather strong sub-acid cherry flavor; quality, very good; medium late, and ripens its fruit evenly for a Duke. Origin France.

Olivet: Tree a very strong, rather spreading grower, from most reports unproductive. Fruit, large, roundish oblate; stem, variable, mostly short, stout, color dark red; flesh, tender, juicy, with sprightly sub-acid flavor. Season medium late.

\section{Two Promising New Cherries}

Dikeman (Bigarreau): Size medium, on young trees about the size of a Gov. Wood; on old trees, larger. Shape truncated heart, flattened. Color, very dark liver, nearly black. Flesh very firm; juice 



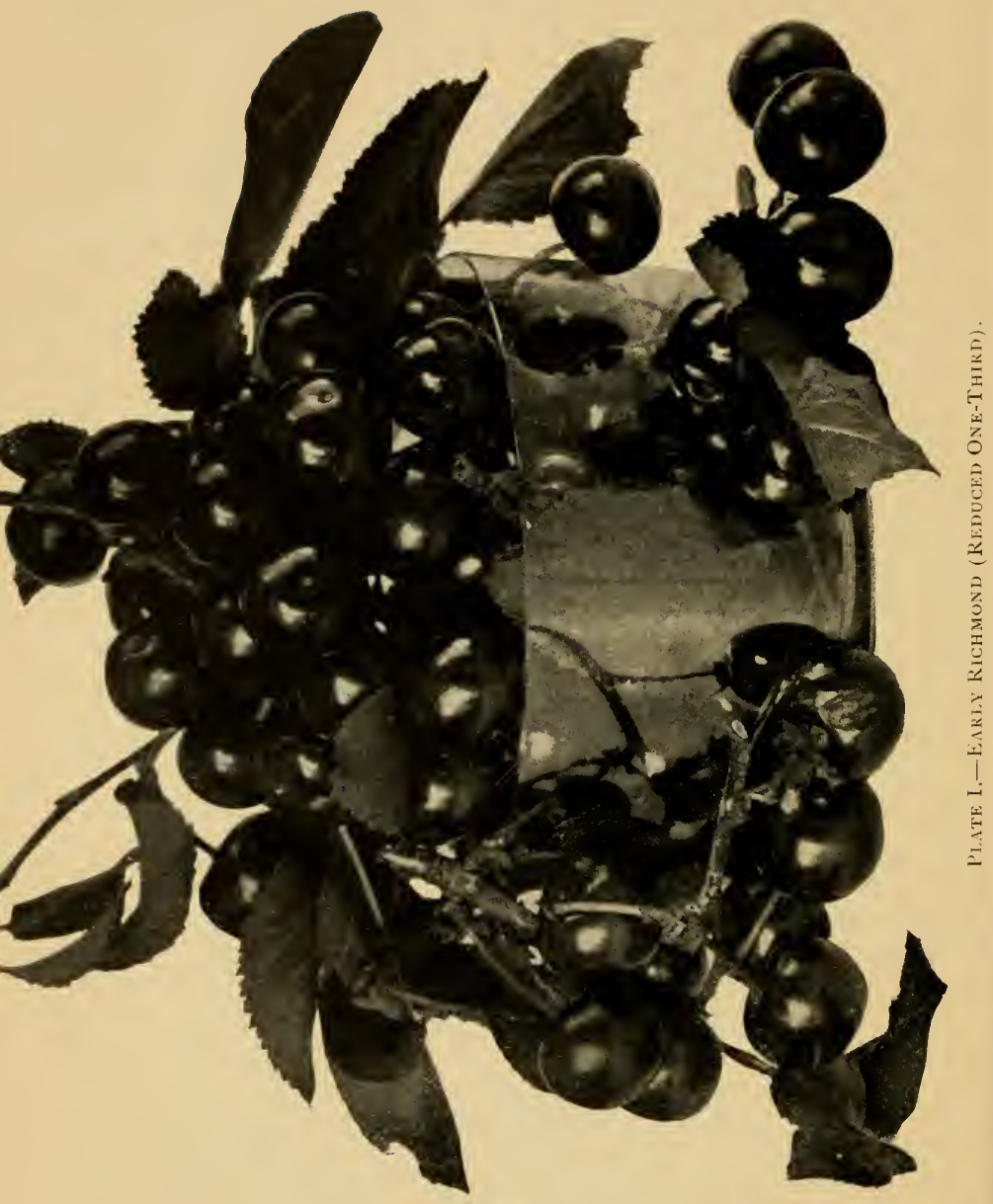


purple. Skin rather tough, rarely cracks or rots. Flavor sprightly, sweet. Ripenș after English Morello. Its season here in Oceana county, Mich., is from August ist to September ist. Tree very thrifty, upright grower ; begins fruiting young, but requires age to lay on profitable crops. Description furnished by Mr. Geo. A. Hawley, Hart, Mich.

Cook's Imperial: "This cherry was originated by Mr. Steven Cook, of Benton Harbor, it being a seedling of the Napoleor Bigarreau from one of the 500 pits of this variety of cherry that he planted in an experimental way. It resembles the Black Tartarian in shape, flavor, length of stem, and color, but is about ten days earlier in ripening, and larger.", (West Michigan Nurseries, Benton Harbor, Mich.)

\section{Harvesting, Packing and Marketing the Fruit.}

With the majority of growers; the methods of harvesting and packing the fruit have changed but little in the past few years; the principal points of importance are, care in picking the fruits with the stems on, and in not pul. ling the spur off to which the stem is attached. Throw all inferior, bruised or decayed fruits on the ground rather than in the basket, and thus avoid a mussy lot of fruit for the packers to cull over. Have good ladders and pick all the fruit you can from thence, rather than climb around in the tree and break the limbs and fruit spurs. The fruit should be set in the shade or taken to the packing house as soon as picked. Baskets not larger than eight or ten pounds should be used in picking. The packing house should have tables or frames with canvas bottoms on which to carefully lay the cherries for sorting into packages. The fruit in package should be uniform throughout and tastefully faced to attract the attention of the fastidious, who will pay the highest market price. Two pickings are usually all that are necessary to clean up the trees.

One of the most successful Michigan growers, Mr. Benton Gebhart, Hart, Oceana Co., Mich., harvests all of his cherries, both sweet and sour, by spreading sheets under the trees; the pickers then clip the fruit off with scissors, leaving about a half inch stem with the fruit allowing it to drop on the sheets. Mr. Gebhart is far better satisfied with this method, than with the usual way, as there are no fruit spurs pulled off as in picking. The pickers are well satisfied to do the work in this way. The fruit is sorted from the sheets into the market packages, and Mr. Gebhart, claims he gets on an average 75 cents more on a 16 quart crate of cherries with clipped stems than for unclipped. This leaves a clear profit of 40 cents per crate over the old way in harvesting the crop. It takes from two, to two and a half quarts more of clipped stem fruit to fill a 16 quart crate, than where the whole stem is left on.

To what extent the clipping of the stems is practıcal the writer does not know, but it is a practice that is worthy of trial in all sections. 
The problem of marketing the fruit is a varied one, as transportation, demands of the market for different kinds of packages, near by or far away markets, with many other conditions, must ever be considered, and in a measure must be worked out individually. Where there is a large number of growers by combining forces they may secure shipping privileges that an individual could never get. The California Sweet Cherry is always seen in the Eastern Markets in the eight and ten pound boxes, and this package may well be called an ideal fancy package. The Eastern Growers use largely the sixteen quart berry crate and, in a small way small six to eight pound baskets, for local markets. The writer has used the eight pound box such as comes from the west, but eastern grown cherries in the same box will not bring as high a price as western grown. The chief complaint comes from the fruit stands, and is to the effect that eastern grown cherries will not hold up as those from California, for this reason, there is much greater risk from loss by rotting. However, this need not discourage the Eastern grower, as there is always a good demand for home grown sweet cherries; the dark fleshed varieties selling much better than the light fleshed. In conclusion it may be said that we all know that the first class article tastefully put up is always in demand, so let us grow more first class fruit. 



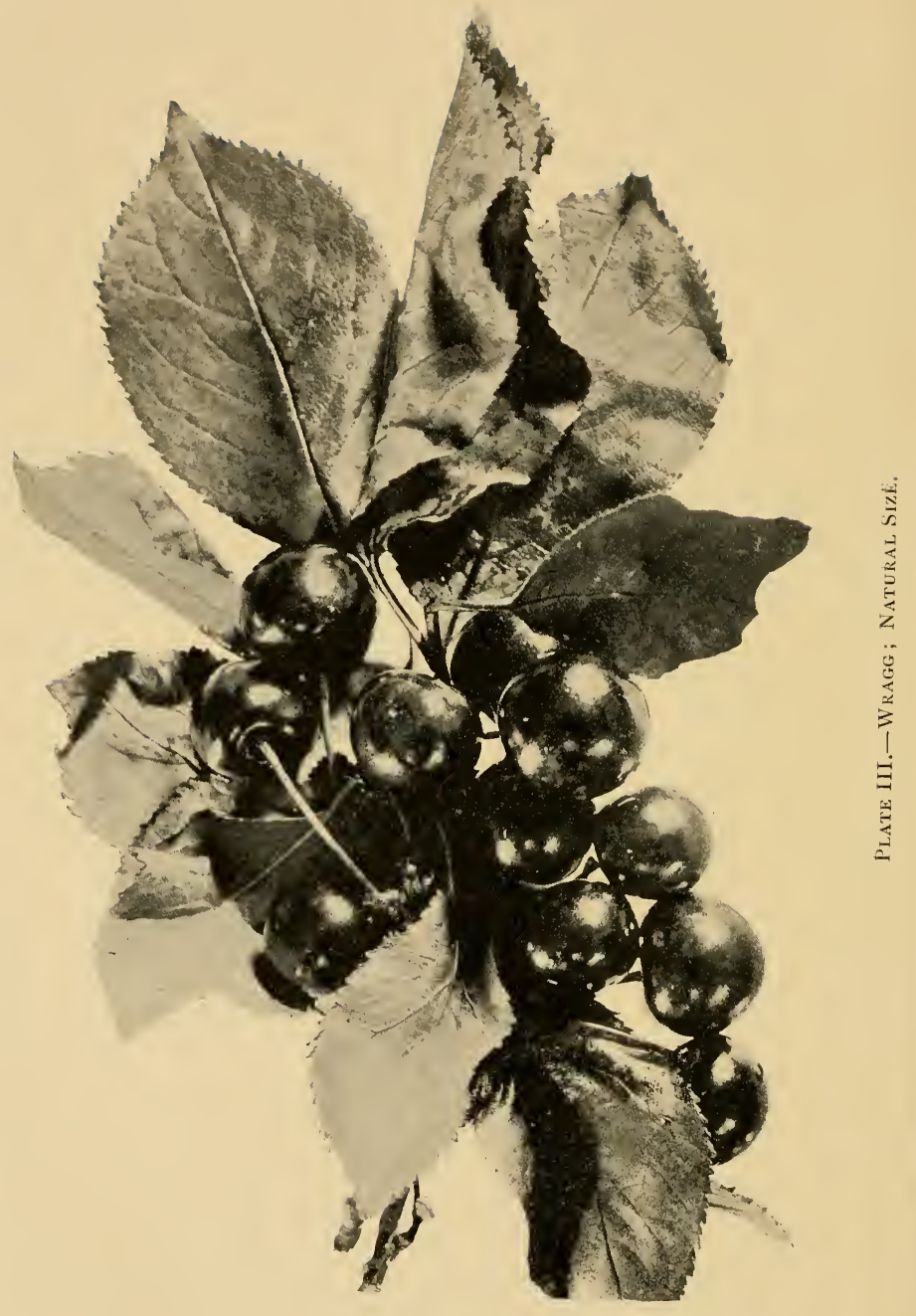




\section{SOUR CHERRIES}

The cherry was introduced into this country by the early settlers who brought it from Europe.

It probably came from the two species of Europe, Prunus Avium (Sweet cherry) and Prunus Cerasus (the Sour cherry). This part of the paper will be devoted to the latter species, or sour cherry.

There are a great many varieties of the Prunus Cerasus or Sour cherry now grown in the United States and Canada. Many of the newer varieties were produced by the planting of seed in the east and central states. Within recent years, a large number have been imported from Russia, and some of the older varieties came from Western Europe.

In all branches of pomology there have been enthusiasts who have been determined to develop varieties of fruit of one class that would be more adapted to the varying conditions of their section. In the development of the cherry, one of the foremost workers was the late D. B. Wier, of Lacon, Ill. He early recognized the fact that the need of the Northwest was new varieties, and so planned to improve the already known sorts of the time by growing seedlings. In Mr. Wier's catalog dated r897, he says,

"Twenty years ago I became greatly interested in cherries, and on reading the subject up, I founa that there were but two or three varieties that could be depended upon to stand our winters here in the Northwestern States and give regular crops and these had fruit very poor in quality. So I determined to see if I could obtain new varieties from the seeds of our hardiest sorts, that would prove superior to old varieties. I selected the seed and grew thousands of seedlings." Of these numerous seedlings produced but few are left to tell of the zealous work.

Among a large number that have been discovered the best sorts now in the trade are, the Northwest, or Wier's No. 29, Dan Wier, or No. I I, Wier Nos, 2 (Starr), 44 (Periam). The most promising are the first two mentioned sorts which deserve recognition, (see description page 34 ). The others in some localities may be superior to the standard sorts, such as Early Richmond, Montmorency Ord., but in other sections may be less valuable.

Russian varieties were brought from Europe under the idea that a quality of hardiness would be introduced which was very much needed in the cold Northwest. After a thorough test of the varieties imported, leading growers in the Northwest made the following report and it coincides with results at the Iowa Experiment Station. 
Early Morello, Orel No. 23, Sklanka, King's Amarelle, Duchess d' Anjouleme, Cerise de Ostheim, and Terry, (see descriptions) are the hardiest and most productive. To say they are more hardy in both tree and fruit buds than the already known sorts which are called "Standard varieties " would not be correct ; but to say they are as hardy in tree, and, under some conditions, more so, would be making a correct statement based upon the experience of many growers.

Of the newer varieties that have appeared in the past five or ten years, it is questionable as to their value, but some of them show promise, and it is quite probable they will find a place among the already known varieties.

The varieties that are more widely grown than any others are the Dyehouse, Early Richmond, Montmorency, English Morello, and Wragg. The three former belong to the Montmorency group (See classification) being light red in color with colorless juice and flesh. Many growers regard them as the most profitable sorts to grow. One advantage they have over the two last varieties is the freedom from leaf-spot (Cylindrosporium padi) which is often times very serious, especially where the trees are on low ground and if the weather is damp and wet. They ripen earlier, and for this reason may be more profitable.

The English Morello has been found to be susceptible to the leaf-spot fungus, as is also the Wragg, and the other dark juiced sorts. During the past seasons this disease has injured and damaged large plantings of dark juiced varieties. It is said that these late ripening sorts are more firm and stand shipping very well.

The growing of sour cherries throughout many parts of the United States and Canada, is increasing each year. Especially in the Central west, the rapid enlargement of plantings of the good sorts is remarkable. In the State of Iowa alone it is very marked. The increase in the number of trees in the past decade is something marvellous, although at present in most localities there are not enough cherries grown to supply the home demand.

From the statistics of 1890 , we find in Iowa only 199,000 trees, while in 1900 the number had increased to nearly 800,000 . This shows an increase of nearly one hundred per cent, and it was quite generally distributed throughout the state. In one county alone, the number of trees increased from 1,374 in 1890 to 13,980 in 1900 . This fact points to the increasing interest in the growing of this fruit which has so long been neglected. It is a fine fruit and the demand is always good. It offers one of the best fields for fruit growing that the writer knows of.

Why this fruit should have been so little planted can only be accounted for by the ripening period of the fruit and the importance of quick handling. The season ranges from middle of June to the middle of July. Oftentimes when the weather is very hot and unless the fruit is marketed the same day 
it is gathered it is not in marketable condition, and often too soft to be used. The trees are shapely and of medium size and could be grown on the lawn thus being used both for ornament and use.

In the propagation of the cherry, it has been found that they can be more successfully budded than grafted; one year old seedlings are generally used for this purpose. There are only two commercial stocks, the Mahaleb and Mazzard. These stocks are imported from Europe where they are grown in large quantities. Mahaleb has been found to be hardier than the latter, but is not sufficiently hardy to stand the rigorous winters of the Northwest.

All commercial varieties on the market, are now propagated on one or the other of the above stocks, and where they are to be planted in the cold sections of the prairie states, north of the $4 \mathrm{I}^{\circ}$ of latitude, it is a very good plan to plant the trees, six to twelve inches deeper than they stood in the nursery row. This is very necessary on high rolling land which is the most suitable for cherry orchards.

The sour cherries have been conveniently divided into four distinct groups by G. Harold Powell formerly of the Delaware Station, now of the U. S. Department of Agriculture, and also by the writer in Bulletin 73 of the Iowa Station: these are Montmorency, Morello, Brusseler Braune and Vladimir.

The Montmorency Group is distinguished by the fruit having colorless juice, flesh whitish with a light red tinge. The trees are rather strong growers with moderately strong branches; leaves large, thick and usually coarsely serrated.

The Morello Group has dark colored fruit, flesh dark, juice colored. The trees are small with slender branches. Foliage medium to small, rather thick, serrated.

The Brusseler Braune Group produces fruit of a dark color. with dark red flesh. The juice is usually highly colored. The stem is long and moderately stout. The trees are large, upright, compact and round-topped. It is made up of Russian or German varieties.

The Vladimir group is composed of Russian varieties. The trees are compact with slender, willowy-like branches. Fruit dark colored with highly colored juice.

Below are given descriptions of the old and new sorts, in their respective groups.

In varieties of the same group there is such a slight variation that oftentimes it is a very difficult thing to distinguish between the varieties. Where they are in different groups, one being light colored with colorless juice, and the other being dark colored with colored flesh and juice, it is very easy to identify them.

The following descriptions are intended to aid in the identifying and classifying of the many varieties now grown in the United States and Canada under the most recent nomenclature. 
Amarelle Hative. (Morello Hative) (Early Amarelle) Montmorency : Imported by Prof. Budd and disseminated by him. H. A. Terry of Crescent, Iowa, reports it as a good bearer ; fruit resembling Early Richmond in appearance and very good for canning. It does not seem to possess any qualities which would justify its extensive planting or superseding varieties commonly grown.

Baldwin. Morello: This variety is reported by S. J. Baldwin of Seneca, Kans., who introduced it, to be from a sprout of the Early Richmond.

It is reported by some growers to be almost identical with Northwest or Wier's No. 29. In foliage and growth of tree there is considerable difference. The Northwest has an obovate leaf with serrate margin, while the Baldwin has an ovate leaf with crenate margin. The leaf of the former is thin and even, while the latter is thick and rugose. The Baldwin has a strong, spreading top, while the Northwest is more slender and upright. The twigs of the former are larger and heavier. It is a very promising sort.

Bessarabian. (No. 62), Brusseler Braune: Imported by Prof. Budd in 1885 , and has been widely disseminated as Number 62 .

Color dark red to almost black at maturity; size medium ; stem long and slender $1 \mathrm{x} / 2$ inches to 2 inches long. Cavity shallow and broad; suture very indistinct ; skin tough and thin ; apex slightly depressed ; flesh colored and meaty ; juice colored; quality good ; flavor, acid with slight astringency; season, July ist.

The fruit colors deeply some time before maturity, and if picked as soon as colored, is acid and astringent, but when ripened on the tree it has a pleasant flavor.

Brusseler Braune. (Griotte du Nord), Brusseler Braune: Form, roundish, heart shaped; size medium to large ; stem, moderately stout, long, $13 / 4$ inches; cavity, narrow, deep, slightly lipped in some specimens; apex, roundish, flattened; skin, thin and tender; color, dark red; flesh firm, crisp with pinkish juice ; quality, good ; flavor, sprightly acid.

Tree medium to large, very upright, quite compact; branches long, slender, sometimes pendulous ; twigs are light gray with numerous lenticles; leaf medium thick, slightly roughened; dark green on upper surface, much lighter below ; narrow, obovate, sometimes elliptical, serrated ; often poor bearer; very late in ripening, July 15 to 25 .

Prof. Budd introduced this variety in 1883 from Russia, and states it is greatly prized on the sandy plains of East Poland. There is great confusion in the nomenclature of this variety. The Lutovka, George Glass, Orel No. 27, and Bessarabian are sometimes mistaken for it, but they vary considerably, both in tree and fruit, and can be readily distinguished. Brusseler Braune is more valuable than any of them, and in some localities may prove to be a good, regular bearer, but here in Iowa is a very uncertain, light bearer.

Corning. Morello or Brusseler Braune : Originated by A. F. Collman, Corning, Iowa. Fruit, heart shaped, medium or above ; cavity, moderately deep and narrow ; stem, medium, stout, I to I I/ $/ 4$ inches ; suture, wanting; apex, slightly flattened; skin, moderately thick and tender ; color, red; flesh, firm and breaking; juice, slightly colored; stone, medium, ovate; quality, good; flavor, briskly sub-acid ; cross between Wragg and Lutovka; season, late; a promising sort; productive. 
Duchess d'Anjouleme. Montmorency : Fruit oblate; size medium or above; cavity very small, one inch; suture indistinct; apex rounded, slight depression ; color bright red ; flesh soft ; flavor sprightly acid ; quality fair; season June I 8th. Fruit resembles Early Richmond somewhat but is a trifle larger and juice not so watery. Tree large, upright, slightly spreading; branches stout; leaves medium, serrated; not much different from the Early Richmond in general appearance. This was imported by Professor Budd from Russia. It is the most productive and regular bearer of his collection. Tree very hardy and vigorous. It may prove to be a valuable variety where the Early Richmond does not succeed. Reported by some growers as not very productive.

Dyehouse. Montmorency : Form round, slightly oblate; size medium to small ; cavity deep, rather broad; stem stout and short- $3 / 4$ inch to $1 \mathrm{x} / 4$ inch; suture very indistinct; apex very slightly depressed; skin thin ; color bright red; flesh soft, juicy; juice colorless; stone small, round; quality very good; flavor slightly acid; fruit is a little smaller than Early Richmond and Montmorency.

Double Natte. (Riga I8,) (Dopplette Natte) Morello: Form slightly oblate, obscurely heart-shaped ; size large ; cavity broad in some specimens ; very large, moderately deep, variable; stem slender, I to $13 / 8$ inch; suture very indistinct; apex very slightly depressed; skin thin, tender; color dark red, getting nearly black at maturity; flesh firm, crisp, with deeply colored juice; stone nearly spherical; quality very good; flavor rich, mildly acid; ripens from June $22 \mathrm{~d}$ to July ist. Tree of medium size, spreading and open; branches moderate size and slightly drooping. Very hardy and thrifty. Productive. A fine sort to eat out of hand.

Early Morello. See Orel No. 23. Montmorency: There seems to be a great deal of confusion concerning this variety. In recent years there have been two distinct varieties disseminated under this name,-one from Rosedale, Kansas, introduced from Germany, and one by D. A. Reed of Nebraska. Then the one imported by Professor Budd as Orel No. 23 is given as a synonym of this variety, and rightly, too. Fruit has light colored juice while those under this name from Kansas and Nebraska are dark cherries with highly colored juice. There is no doubt that these are the old Wier's No. 29 or Northwest, sent out by Ia. Experiment Station. G. A. Marshall, Arlington, Nebraska, reports it identical as also does Mr. H. A. Terry, Crescent, Iowa, both having grown these varieties for a number of years.

Early Richmond. Montmorency : Fruit medium in size, light red, roundish oblate: skin thin, translucent; flesh watery; juice colorless; flavor acid; quality good; stem I inch to $\mathrm{I} / 4$ inch long; stone round, oval; season June I $5^{\text {th }}$; leaves thin, long, inclined to ovate; probably the most commonly grown cherry of the sour sorts; an early and productive bearer, but tree inclined to be short lived.

This is one of the most commonly grown varieties and ranks as one of the best of the old varieties. The tree is hardy and vigorous but is said to be short lived. It is a profuse and regular bearer. Fruit matures early, season middle of June. Fruit only keeps a day or two after picking. A local market should be supplied. A poor variety for shipping.

English Morello. Morello: Fruit, medium to large; form, round ; obscurely, heart shaped ; stem, moderately stout, II/4 inches ; apex, round ; 
color, dark red; juice, abundant, colored, very acid; season late about July $5^{\text {th }}$ to 2 oth in central Iowa; tree, medium, spreading, slender, hardy, productive. This is one of the oldest varieties and has been grown in this country for many years. It is classed as one of the best sorts, being very productive and hardy, firm and an excellent shipper.

Goodspeed. Montmorency : Form, oblate, slightly heart shaped; size, medium large ; cavity, deep and broad. Stem, short, stout $\mathbf{I}$ inch ; suture, roundish slightly flattened; skin, thin and tender; color, dark red; flesh moderately firm, tender, uncolored; juice uncolored; stone, almost free, medium, roundish ovate ; quality, good ; flavor, slightly sub-acid. Ripens just after the Early Richmond.

Griotte du Nord. (See Brusseler Braune): Prince in his Pomology published in $18_{3} I$ gives this as a synonym of the Brusseler Braune and described the fruit as follows : form almost spherical; medium size; the skin and flesh both dark and red color; flavor acid, sometimes bitter. He says it was grown much in northern France, Belgium and Holland. The Dutch obtained this variety from Russia. Professor Budd in his notes on Russian importations reports this variety as grown in North Silesia. Fruit large, nearly black, flesh firm. Fruit matures about July 2 oth. Tree is very similar in habit of growth, size and hardiness to the Brusseler Braune. Of little value.

June Amarelle. Montmorency : Specimens of this variety were received from Mr. H. A. Terry, Crescent, lowa. Form round, oblate; size large ; cavity variable; stem thick, $7 / 8$ to $1 \frac{1}{4}$ inches long; suture indistinct, marked by faint line; apex flattened; skin thin, rather tough; color light red; flesh yellowish. juicy; juice colorless; stone medium to small; quality good, flavor sprightly sub-acid.

Introduced by Professor Budd in $188_{3}$. Synonyms Juneat Amarelle, Amarelle, June Morello. Should be further tested.

Homer. Montmorency: F. Yahnke of Winona, Minnesota, reports having grown this variety for a number of years. It is seedling that came from New Haven, Connecticut; said to be productive and hardy. No fruit of this variety was received. It may be valuable for the cold sections of the Northwest.

Late Richmond. Montmorency : Medium round, conical cherry with a thin, translucent skin; light red in color ; stem thick, 1 to $1 \mathrm{I} / 4$ inches long ; cavity shallow, broad; seed round, large ; flesh tender and juicy ; juice colorless, not as watery as Early Richmond; season a week to ten days later; flavor acid; quality very good. The Montmorency is a few days earlier in ripening, scarcely as acid, and usually a little more conical in shape.

Some growers report this variety unproductive. Others seem to think it moderately productive. English Morello or Wragg will doubtless be more valuable where a late variety is desired.

Lutovka. (Galopin). Brusseler Braune: Fruit of this variety was received from Atlantic and Amana, Iowa; also from our grounds. This fruit seems to be very distinct from the Brusseler Braune. It is not a synonym of that variety. Form oblate, obscurely heart-shaped; size medium, $I / 2$ by $3 / 4$ inches; cavity wide and deep; stem $I$ to $I 3 / 8$ inches; suture prominent; apex depressed; skin thin and tough; translucent; 



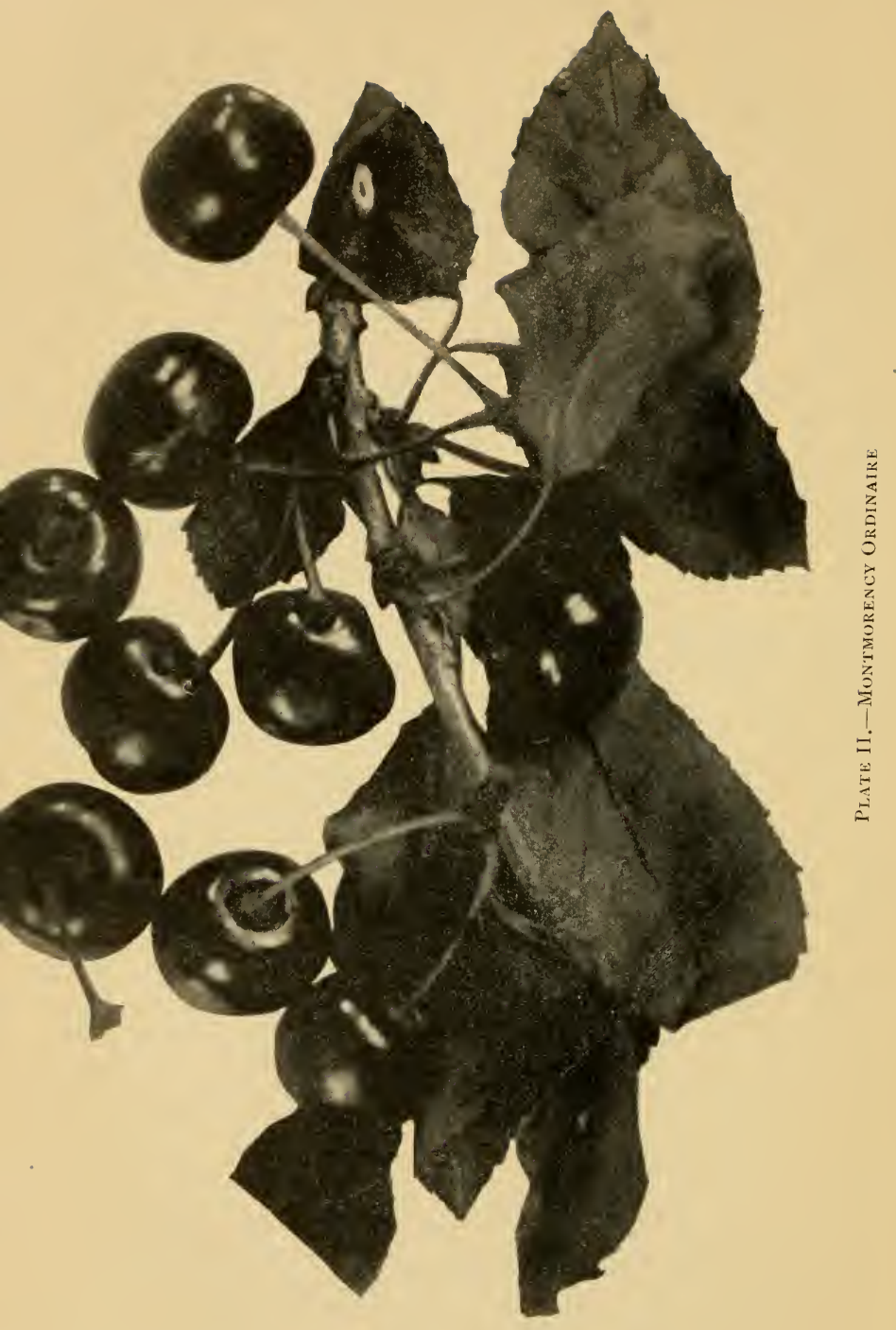


color red; flesh colorless, meaty, free from stone; juice colorless; stone flattened, large; flavor slightly acid ; quality good.

Tree is large, strong, upright; branches slightly spreading ; leaves large, elliptical, ovate, acute, leathery; reddish brown twigs, coarsely serrated.

This variety was imported by Professor Budd in $188_{3}$ and he states that it was much grown in Poland, North Silesia, and South Russia.

Lithauer Weichsel. Vladimir: Form round oblate, size small, 9-16 inches wide, 7-16 inches long; cavity, narrow, shallow; stem long, slender, $1 \mathrm{x} / 2$ inches ; apex, depressed; skin, tough ; color, dark red; flesh, red, almost purple, meaty ; juice, red ; stone, roundish, large ; quality, fair ; flavor, acid.

Morello Fouche. (Fouche's Morello) Morello : Fruit, roundish oblate ; size, small; cavity, shallow and broad; stem, slender, $1 \frac{1}{2}$ to $13 / 4$ inches long; suture marked by a line; apex, flattened, slightly depressed ; skin, thin, moderately tough ; color, dark red to crimson; flesh, firm and breaking ; juice, colored ; stone, nearly round, medium ; quality, fair ; flavor, sprightly sub-acid ; tree, medium to large, upright.

Professor Budd says from Riga, Russia. Of little value.

Montmorency Ordinaire. (Long Stemmed Montmorency). Montmorency : Fruit, roundish oblate to obscure heart-shaped; of light red color with thin and translucent skin and colorless juice; medium size; stem, $\mathrm{I} \mathrm{I} / 4$ inches to $\mathrm{I} / 2$ inches long; cavity of medium depth; suture, very indistinct ; apex, convex ; quality, very good ; flesh, meaty; stone, small and round; flavor, sub-acid; season, June 2 oth to July ist.

The Montmorency group of cherries is probably one of the most confused groups that we have. The Montmorency Ordinaire, Short Stem Montmorency, Large Montmorency, and Montmorency Extraordinaire have practically become synonyms and the same variety and are often found under any of the above names. The Montmorency cherries originated in France, and in Prince's Pomological Manual, published in 1831 , two varieties are described, the Long Stem Montmorency and the Short Stem Montmorency. The Short Stem Montmorency is said to be large and of the best quality but a poor bearer. For this reason it is not widely distributed and Prince says it was found growing only in the gardens of those "who prefer the fine fruit to the quality of fruit."

The Long Stem Montmorency is undoubtedly the Montmorency Ordinaire and the one that is usually propagated simply under the name Montmorency. This same variety is sometimes sold as large Montmorency and Montmorency Extraordinaire, although these names more appropriately belong to the Short Stem Montmorency.

The Montmorency cherries rank among the leading commercial varieties and undoubtedly one of the most profitable to grow.

Note : New York canners are this year showing a marked preference for dark colored cherries.-Secretary. 
Several varieties of the Montmorencies have appeared from time to time, due to local influences, and have given rise to varieties that are now in the trade. Montmorency Extraordinaire does not seem to differ from Montmorency Ordinaire except in the character of the leaf and where this difference is shown it should be classed as a varietal strain and not as a variety.

There is more difference shown in the leaf of the Montmorencies than in any character of the fruit. Short Stem Montmorency has long, slender, spatulate leaves, while the Montmorency Ordinaire has a large oval leaf.

Northwest or Wier's No. 29. Morello: This variety was originated by Mr. D. B. Wier of Lacon, Illinois, who was the originator of several varieties of value. Downing in his manuscript notes describes this cherry as received from a nurseryman under date of July $3,188_{3}$. It was distributed by Professor Budd and H. E. Rowley of Lacon, Illinois, as Wier's No. 29.

Fruit, round, obscurely heart-shaped; medium; cavity, shallow ; size, $\mathrm{I} I / 4$ to $\mathrm{I} / 2$ inches; suture, indistinct ; apex, rounded; skin, tough, moderately thick ; color, dark red to almost black at maturity; flesh, firm, deeply colored; juice, deeply colored ; stone, small, round ; flavor, acid, slightly astringent; quality, medium; season, June $22 \mathrm{~d}$ to July 3 Ist. Tree resembles the English Morello very much in size and habit of growth. It is productive, good size and color and an excellent fruit.

Orel 24. See Lutovka. Morello: Fruit round, oblate; medium; cavity rather deep; stem stout, I to $\mathrm{I} I / 2$ inches long; suture indistinct, marked by faint line ; apex slightly depressed and flattened; skin thin and translucent; color carnelian red; flesh colored and firm; juice colored; stone round, angular; quality good; flavor acid and pleasant.

Ostheim. (Cerise D). Morello : Round and oblate ; medium ; dark red in color; flesh firm and meaty; juice colored; stem $5 / 8$ to I inch long : skin thin and tough; quality fair ; flavor acid and slightly astringent ; tree medium roundish to flat topped, spreading to dropping branches; leaves small to medium; ovate, slightly serrated, leathery; grown in the United States for nearly a century.

Synonyms: Ostheimer, Griotte d'Ostheim, Ostheimer Weischel and Minnesota Ostheim. In the Montreal Horticultural Society Report of I883, Chas. Gibb says that the Ostheim is reported by Director Stoll of Proskau Silesia to be a native of the Sierra Nevada Mountains in Spain, where it was found at elevations of 5,000 to 6,000 feet, introduced into Germany 1687 by a German Professor who grew it in the neighborhood of the town of Ostheim.

Ostheim. (Griotte d'Ostheim). Morello: Fruit round, occasionally heart shaped, below medium; stem long and slender, $1 \mathrm{I} / 2$ to 2 inches; color deep red, almost black at maturity; flesh deep red and firm; juice highly colored; cavity very shallow and loosely attached to the stem ; quality very good; flavor mildly sub-acid; season June $25^{\text {th. }}$

Very similar to the Minnesota Ostheim but ripens a few days later. Imported by Professor Budd in $\mathrm{r}^{8} 8_{3}$. Ostheim is a group name for a class 
of cherries that is just as badly confused as the Montmorency class. The names Ostheim, Griotte d' Ostheim, Cerise d'Ostheim, Minnesota Ostheim and Ostheimer have been used interchangeably. They are undoubtedly slight varietal differences but they are hardly distinct enough to make well established varieties that can be readily separated, or so plainly marked but what one may be substituted for the other. These points of difference have been briefly mentioned in the descriptions.

The developing of specialized strains of fruit is a work that should be encouraged, but they should be put out as improved strains and not as distinct varieties. The Ostheim cherries are a valuable class for the West. The fruit ripens the first week in July, being a black red in color, of good size and flavor and proves a satisfactory variety to grow.

Ostheim, (Minn.) Morello: Form is round, small to medium ; stem slender and long, with a shallow and broad cavity; color is deep red, sometimes black when fully mature; skin is thick and tough; flesh firm and juicy, the juice being brightly colored; quality good; flavor sub-acid, slightly astringent.

Professor Budd says Minnesota Ostheim is much earlier than Cerise d' Ostheim and Griotte d' Ostheim. In Iowa Horticultural Report, I88 I, p. $37 \mathrm{I}$, it is stated that E. Meyer of Saint Peter, Minnesota, imported this variety from his home in north Germany. It has proved very hardy under the trying conditions of the prairie states. The hardiness of the tree makes it a valuable acquisition for Minnesota and the Northwest.

Shadoze Amarelle. (Shadow Morello) Morello: This is one of the latest varieties of the Russian sorts; ripens a little later than Brusseler Braune; season July $15^{\text {th }}$ to $25^{\text {th. }}$ Fruit is roundish conical; medium; cavity small, shallow; stem $\mathrm{I} 1 / 8$ to $\mathrm{I} 1 / 2$ inches, slender; apex rounded; skin thin, tough ; color deep red ; flesh firm ; juice deeply colored ; stone flattish oval ; quality fair ; flavor sprightly acid.

Tree is small, spreading to drooping; branches are dull brown; leaves small, ovate, elliptical, sometimes smaller at base, thus being ovate; slightly serrated; color light green.

Imported by Professor Budd in 1883 . In bulletin No. 18 of the Iowa station he reports it as a heavy and regular bearer. On account of its lateness it may be worthy of trial in a commercial way.

Shubianka. Vladimir: Fruit is round, small; cavity broad and shallow; stem long and slender; apex flattened; skin tough and thick; deep red; flesh firm, with highly covered juice ; stone round, rather large; quality poor ; flavor sprightly acid, astringent with bitter taste after.

Silver Thorne. Morello: A variety that is supposed to have originated in Muscatine County, Iowa, about fifty years ago. W. S. Fultz of Muscatine describes it as follows: "In size and color about the same as Early Richmond, and resembles this variety in tree and fruit. Flavor not so acid and flesh firmer; fairly productive. Has been propagated from sprouts and comes true.

Sklanka. Montmorency: Fruit roundish oblate, medium ; cavity broad, shallow ; stem $7 / 8$ to $\mathrm{I} 1 / 8$ inches ; suture not marked; apex flatten- 
ed ; skin thin ; color light red when fully ripe ; flesh soft, juicy ; juice uncolored rather watery ; stone medium size ; quality poor to fair ; flavor acid; season June 15 th to $25^{\text {th }}$.

Tree is large, spreading, with strong branches slightly dropping, foliage abundant, medium, ovate, crenate, acute; twigs reddish brown; very hardy and vigorous.

It is one of the best Russian sorts and has been widely disseminated and deserves to be further tested.

Spate Amarelle. Montmorency : Fruit oblate, medium; cavity broad, shallow; stem I I/8 to $11 / 2$ inches, usually not variable; apex flattened and depressed; skin translucent, thin; color pinkish yellow and light red; flesh soft ; juice uncolored; stone small ; quality fair ; flavor lacking in richness; season June 2 oth.

Tree large, upright, spreading, quite open; bark reddish to dark brown ; leaves small to medium, elliptical, double serrate, of leathery texture ; foliage only moderately abundant.

This variety has been mistaken for the Shadow Amarelle. Hedrick in Utah Station bulletin No. 64 says the fruit has dark colored juice and the trees dwarf, which closely corresponds to the Shadow Amarelle as grown here. Imported by Professor Budd in 1883 . In his notes on cherries he reports that this variety was much grown in East Poland and North Silesia.

Moderately productive and hardy. May be of value.

Strauss Weichsel. (Strauss) Brusseler Braune : Fruit conical, truncate ; small to medium ; cavity deep, round; stem $1 \mathrm{I} / 4$ inches, slender; suture indistinct; apex smooth, lacking depression; color almost black; flesh firm, colored, juicy; stone globular; flavor acid, astringent; quality medium.

Tree of medium size, upright grower; leaves medium ; moderately hardy; a shy bearer. No value for commercial purposes.

Suda Hardy. (Suda) Morello: Fruit is heart-shaped, roundish,medium ; cavity moderately deep and narrow ; stem medium stout, I to $11 / 4$ inches ; suture marked with line; apex rounded; skin thin and tender; color almost black when ripe; flesh slightly colored, moderately firm; juice almost colorless; stone rather long, oval, medium ; quality fair to good, slightly acid.

It is hard to distinguish the fruit of this from Wragg and English Morello, the only essential difference being in the stem, but the tree is more upright and can thus be readily distinguished from these varieties. It is a good, prolific bearer with him. The photographs of these varieties bring out the essential differences of stems which can be readily distinguished.

Powell in the I 2 th Annual Report of the Delaware Station states that this variety originated at Louisiana, Missouri, and there is no reason to believe that the old tree which was then 22 years old was not an English Morello.

Timme. Montmorency: Fruit oblate, medium ; cavity medium round; stem 1 to $11 / 4$ inches; suture wanting; apex depressed; surface smooth, translucent ; color deep red ; skin astringent ; flesh light red with colorless 
juice ; stone large, round, smooth ; flavor sprightly acid ; season a little later than Early Richmond.

Tree medium to large, strong, hardy ; branches medium large ; upright slightly spreading; leaves medium to small, dark, leathery.

Professor Budd says this variety came from Germany and was introduced by a German in Omaha by the name of Timme who sent scions to the Department of Horticulture of the Iowa state college for propagation.

Terry. Morello: This variety was obtained from H. A. Terry, Crescent, Iowa, who received it from the Iowa state college as Spate Amarelle, but when it fruited it proved to be different from this variety. The State Horticultural Society, after examining the fruit, named it Terry. It has been widely disseminated under this name.

Fruit round, slightly oblong ; large ; cavity, very shallow ; stem rather slender $I$ to $I 3 / 8$ inches; suture very indistinct, marked by straight line ; apex convex, slightly depressed; skin tender; color dark red to nearly black at maturity; flesh firm and crisp; juice colored; stone small, slightly oval; quality good; flavor slightly acid and rich.

Tree medium upright, round topped, hardy. Many growers report this variety a good commercial sort. Should be valuable.

Tubbs. Morello: This is said to have originated at Iowa City. Fruit is round and slightly heart-shaped ; size about medium ; cavity deep and narrow; stem moderately thick, $11 / 4$ to $13 / 8$ inches long; suture very indistinct ; apex convex; skin thick; color dark red; flesh crisp and meaty ; juice highly colored; stone small, round; quality very good; flavor slightly acid. Promising.

Wier's No. 2. (Starr) Montmorency: Fruit oblate, conic, medium ; cavity shallow, broad; stem $3 / 4$ to I inch; suture slight; apex small depression ; color dark red ; flesh firm, meaty ; juice dark ; stone oval, medium ; flavor mildly sub-acid ; quality fair ; good, regular bearer ; season a few days earlier than Early Richmond.

Tree medium to large, upright and spreading ; leaves doubly serrated, medium to large; foliage only fairly abundant; somewhat larger than Wier's No. 44. Originated by D. W. Wier of Lacon, Illinois. One of the most productive of the collection. Fruit about the size of Richmond; tree hardy and worthy of trial.

Wier (Dan or No. II.) Morello: The Dan Wier, or No. I I as de. scribed by H. E. Rowley of Lacon, Ill., who was foreman under the late D. B. Wier is as follows: "It is a very early cherry ripening fully as early or a little earlier than Northwest and Early Richmond; is a more upright grower ; a very prolific bearer ; is more hardy in tree and fruit bud than Wier's No. 29, or Northwest ; fruit is black, or nearly black ; a little oblong or heart-shaped; juice dark, and flavor sweeter than many of the sour sorts.

Wier's No. I2. Morello: Fruit long, roundish cordate, medium ; cavity moderately deep and broad; stem long, stout, $11 / 2$ to 2 inches; suture obsolete; apex roundish; skin thick and tender; color dark red; flesh firm and crisp; juice colorless; stone large, oval; quality fair ; flavor sprightly sub-acid; season from July 12 th to 2 oth; latest of the Wier seedlings.

Tree is of moderate size, spreading to drooping; leaves medium to large, leathery ; decidedly ellıptical ; dark brown twigs; foliage good ; hardy and moderately productive. 
Wier's No. 44 (Periam) Montmorency : Form oblate, small to medium ; cavity shallow; stem one inch ; color light red; skin thin and tender ; flesh tender, light colored, with uncolored juice ; flavor acid; quality moderately good; season late June. The fruit and tree is a trifle smaller than the No. 2 .

Tree medium or slightly above ; an upright, spreading, habit ; branches moderately strong; foliage is thin ; leaves small to medium, decidedly ovate, only slightly serrated, fine texture.

Wheeler. Morello: A seedling of English Morello said to be a little larger, and of good quality. Originated by $\mathrm{H}$. J. Wheeler of Carnforth, Iowa, who says it is a good bearer and hardy. Not introduced.

Wragg (English Morello) Morello: Fruit heart-shaped, medium to large ; cavity deep and broad ; stem medium slender, $\mathrm{I}$ to $\mathrm{I} \mathrm{I} / 2$ inches ; suture nearly obsolete; apex roundish, sometimes slightly flattened; skin tender and thin; color dark red; flesh firm, crisp, with colored juice; stone small, roundish ovate; quality good; flavor briskly sub-acid.

Fruit seems to be a little larger and later than English Morello. It has been widely distributed and is grown in all parts of the Northwest where it is now considered a standard variety.

Vladimir. Vladimir : Fruit round, below medium; color dark red to almost black at maturity ; cavity shallow ; stem slender, $\mathrm{I} 1 / 2$ inches long ; apex with slight depression; suture very indistinct; skin tender; flesh melting and blood red in color; stone round and small; sub-acid with slight astringency; quality good. 


\section{STATUS OF THE CHERRY IN THE UNITED STATES AND THE PROVINCES OF CANADA}

The following circular letter was addressed to each of the Horticulturists of the different Experiment Stations and leading fruit growers in the United States and Canada, and extracts from their answers to the questions submitted to them are herewith published, as it is believed that these will show the condition of the cherry industry in a clearer way than figures, which are, however, published as well :-

"Dear Sir:-I am assisting in preparing a report on the Cherry and the present condition of the Cherry Industry in America, for the American Pomological Society, and should esteem it a favour if you would answer the following questions and return the same to my address :-

I :-To what extent are cherries grown in your State?

2 :-Do both sour and sweet cherries succeed, or if only one class, which?

3 :-Which are the most profitable to grow, sour or sweet?"

Connecticut : I :-Limited ; mostly local.

2 :-Many old sweet cherries scattered throughout the State bear profitably. Of late years, however, young trees have not done as well.

A. G. Gulley, Storrs.

Idaho: 1 :-In large quantities, especially in Northern part of State.

2 :-Both, to perfection.

3 :-No market for sour cherries, except locally. No finer sweet cherries are grown in the U.S., and these are the money makers.

L. B. Judson, Moscow.

Kentucky: I :-Mostly for home use and local market.

2:-Sour cherries more generally grown, and more successful.

3 :-Sour, probably. Clarence W. Mathews, Lexington.

Nebraska: I :-Very generally grown in home orchard; few large commercial orchards.

2:-Sour.

3 :- - Sour.

Nevada: I :-Very little.

R. A. Emerson, Lincoln.

2 :-Both.

Rhode Island : I :-Very little.

P. Beveridge Kennedy, Reno.

2 :-Sour.

3 :-Sour.

Utah : I :-

FRED W. CARD, Kingston.

2 :-Both grow, but the sweet cherries are not hardy in all parts.

3 :-Sweet.

W. N. Hutr. 
Wyoming: 1:-Only a few trees in home gardens and orchards. 2 :-Sour.

B. C. BufFaM, Laramie.

Colorado: I :-Largely grown, especially in the northern part of the State; not generally grown on the western slopes.

2 :- Both in the fruit section of the Western slopes: the sour kind only are grown on the Eastern slope.

W. PADDOCK, Fort Collins.

Florida : I :-Cherries are not grown in this State.

\section{H. HaRold Hume.}

North Carolina : 1 :-Grown in considerable quantities in certain places in this State.

2 :-Both sour and sweet cherries succeed very well in the western part of the State.

H. Harold Hume, Raleigh.

South Carolina: 1 : - Not to any extent for market ; only a few trees for home use.

2:-Sour in the Western part of the State; sweets do well near the mountain section.

3 :- -Sour.

C. C. Newman, Clemson Agricultural College.

Virginia : I :-Not grown extensively for market.

2:- Both groups succeed well in Virginia, but the sour cherries appear to be better adapted to commercial culture. This may be due to the fact that a large number of the sweet cherries have been propagated on Mahaleb stocks and are, therefore, neither long lived nor hardy(?) Field Mazzards are very hardy and when the improved sorts are grafted on Mazzards they will probably succeed much better in a commercial way.

3 :-The sour varieties have been more profitable, but there is no reason why this should be so if above condition (2) is corrected and if the grower will practice up-to-date methods in handling and marketing. H. L. PRICE, Blacksburg.

Washington: I :-Sweet cherries are grown to a considerable extent.

2 :- - Sour and sweet cherries.

3 :-Sweet.

D. C. Mooring, Pullman.

Alabama : I :-Very limited.

R. S. Mackintosh, Auburn.

Arizona: I :- Not to any extent. A few in the northern part.

Chas. A. Van Der Veer, Phoenix.

Arizona : 1: To a limited extent in a few isolated mountain localities.

R. H. FORBEs, Tucson.

Arkansas : Do not know of any cherry orchards in the State.

H. T. BRADFord, Little Rock.

Arkansas: I :--Limited, but are increasing since they have been found to do well. 2 ;-Sour.

Ernest Walker, Agricultural Experiment Station.

California : $1:-$ To a large extent.

2 :-Both.

$3:-$ Sweet.

EXPERIMENT STATION. 
Colorado, Denver.

Delaware: I :-Extensively for family use ; limited number grown commercially.

Chas. Wright, Seaford.

Delaware: I :-Only a few grown.

2 :-Sour cherries do best, except perhaps in northern part, where the sweet varieties do well.
3 :-Sour.
C. P. Close, Newark.

Georgia : I :-Not commercially. Local markets throughout Middle and Northwest supplied with a limited quantity, especially in mountain regions, where almost all kinds do fairly well. Extensively for home use.

2 :-Except in northwest and mountains of north and northeast sweet cherries do not succeed.
3 :-Morellos.
H. N. Starnes, Experiment.

Idaho: I :-In some parts of the State, for shipment.

A. H. Hitr, Weiser.

Iowa : 1 :-Sour varieties succeed well and are grown in all parts of the State except extreme North. Sweet varieties are grown in a limited way in Southern and Eastern sections of the State.

2 :- Sour varieties succeed well.

3:- Sour.

E. E. Little, Ames.

Iowa : $1:-791,327$ trees reported in 1900 .

2 :- - Sweet sorts tender. Sour types succeed.

3 :-Sour.

A. T. Erwin, Ames.

Illinois : I :-Limited. Few commercial orchards.

2 :- Sour only.

J. C. Blair, Urbana.

Indiana : I :-Quite limited.

2 :- -Sour.

3:-Sour.

J. Troop, Lafayette.

Kentucky: I :-For the most part only for home use and local markets.

2 :- Sour cherries more generally and more successfully grown.

$3:-$ Sour.

C. W. Mathews, Lexington.

Louisiana: I :-Not commercially. A few sour varieties in the North.

F. H. Burnette, Baton Rouge.

Georgia : 2 :-Not commercially. Mountain districts in northern part of state would undoubtedly be suitable for a number of varieties, but the industry is not developed. Probably about 50,000 bearing cherry trees of standard varieties in the State.

Wilmon Newell, Atlanta.

Kansas: 1 :-Not largely grown commercially; quite generally planted in home orchards.

2 :-Sour; sweet cherries uncertain.

3 :-Sour.

A lbert Dickens, Manhattan.

Maryland : I : - Not as a commercial crop.

2 :-Both grow and fruit well.

3:-Sour.

W. N. Hutr, Agricultural College.

Montana: I :-Practically the only sections of the state where cherries are grown are in the Bitterroot, Flathead, and Yellowstone valleys. Russian varieties succeed fairly well in the higher and colder altitudes. 
2:-In certain sections, sweet cherries. Sour varieties are on the whole more successful.

3 :-Sour.

R. W. Fisher, Bozeman.

Maryland : 1 :- There are no large cherry orchards in the state, cherries being mostly grown on the farms.

J. G. SChONFARBER, Baltimore.

Michigan: I :-2 117 acres of cherries in this State. Cherry growing is considered valuable from a conimercial standpoint, but on a smaller scale than other kinds of tree fruits.

2 :- Ten acres of sour to one of sweet, the largest acreage being in the western half of the lower Peninsula.

3:- Sour kinds are considered most profitable, being hardier.

T. A. FARrand, South Haven.

Michigan: 1 :-Sour cherries are grown in all parts of the lower peninsula, and to some extent in the upper peninsula of this State. Sweet cherries are grown only in peach regions, for most part on the west shore.

2 :- Both in the regions named above, sour cherries doing pre-eminently well. The industry is threatened by robins and few plantations are now being put out.

3 :-In parts where they will thrive, sweet cherries are most profitable, though competition with Pacific Coast cherries is always to the advantage of the latter.

\section{U. P. Hedrick, Agricultural College.}

Massachusetts : I :-Cherries are but little grown for the market in this state. A great many farmers and others have one or more trees and most of the cherries are consumed at home.

J. Lewis Ellsworth, Boston.

Mássachusetts : I :-Only a very little in an amateur way. Not at all commercially. 2 :-Only sour.

3 :--Sour. $\quad$ F. A. Waugh, Amherst.

Maine : I :-Very slight at present, except for home use.

2 :- - Sour.

3 :-Sweet cherries not sufficiently hardy to be of value in Maine.

W. M. Munson, Orono.

Missouri: I :-Confined mainly to small areas for home use and local markets. There are a few large plantings, however, from which shipments are made.

2 :- Sour cherries succeed admirably. Sweet cherries do not succeed well and are little grown.

3:-Sour.

J. C. Whitten, Columbia.

New York: I :-Sour cherries quite heavily in Western part. Mazzards to a small extent all over the State except Northern part.

2:-Sour, west; sweet in Hudson River valley but equally along lakes Ontario and Erie in peach belts.

3 :- Sour always have a ready market and do not rot as readily as sweet. Canning factories consume large quantities. One dealer in western New York handled 100,000 pounds last year, all of which were canned.

J. CRAIG, Ithaca. 
New Mexico: I :-In small numbers, and usually in home orchards.

2 :-Both, but sour best suited to our conditions.
3 :-Sour.
Fabian Garcia, Mesilla Park.

North Dakota: $\quad$ I:-Cherries are not grown to speak of in North Dakota. Occa. sionally a tree of the sour cherry is hardy, but bears no fruit, the buds winter killing.

C. B. Waldron, Fargo.

New Hampshire: I :-Only here and there a few trees. Some orchards being set.

$2:-$ Both in Southern sections; only sour in Northern.

3 :-Sour by average farmers but with care the sweet are as profitable.

F. W. RANE, Durham.

New Jersey: I :-Sixty-four acres in orchards of an acre or more. As a rule, the sour cherries exceed the sweet in orchards of this sort. The aggregate of sweet cherries grown is considerable, but they are largely the result of a number of trees at each farm.

3 :- Since the sour cherries are the only varieties grown to any extent as a commercial industry, I should regard them as the more profitable.

E. B. Voorhees, New Brunswick.

Oregon: I :-In this State the extent of the culture of the cherry covers 1,200 acres.

2 :-Both. Of the two, the sour is a little more productive, perhaps.

$3:-T h e$ amount produced and sold in the markets in 1903 was 5,000,000 pounds, valued at $\$ 180,000.00$.

George Coote, Corvallis.

Oklahoma : I :-Only for home use.

2:-The sour cherry only is grown. Plantings of the sweet cherry have uniformly failed.

O. M. MORris, Stillwater.

Ohio: I :-Cherry growing on a commercial basis is being taken up by a few of our horticulturists, principally in the Northern part of Ohio. The industry on a large scale is yet to be developed.

2 :-Both.

3 :-Sour.

Pennsylvania : 1 :-Only for home use.

F. H. Ballou, Wooster.

2 :- Only sour cherries succeed, principally because of the excessive rotting of the sweets.

3:-Sour.

G. C. Butz, State College.

South Dakota: I :-Cherries are raised to a very limited extent in South Dakota. The largest cherry orchard I know of which is in the Southeastern corner of the State has about 1100 trees mostly of the Early Richmond kind. This orchard is favourably located on the Missouri River Bluffs. The limit of cherry culture may be said to be the Southern third of the State. In the Black Hills in sheltered valleys some are succeeding with cherries under irrigation. Two main troubles in cherry culture are the tender Mazzard and Mahaleb stocks, both of which root kill. Some of the Russian cherries appear hardy in tree, but the flower buds are tender. However, one of the Vladimir race is doing better in this respect. The sweet cherries are entirely out of the question in this State. For home use the sour 
cherries will do in a limited way in the Southern part of the State with proper attention to mulching to protect the roots. A determined effort is being made by the South Dakota Experiment Station to supply this demand for a hardy cherry by breeding experiments.

N. E. HANSEN, Brookings.

Texas : I :-Not grown, except a few trees here and there.

E. J. Kyle, Austin.

Tennessee: I :-Cannot be considered among the commercial fruit crops. The largest cherry orchard that I know of in the State is owned by Mr. Horace Rainy, of Columbia, and is about sixteen acres in extent. It is devoted entirely to sour cherries and the product finds a profitable sale in local and adjacent markets. Very many of the fruit growers include a few hundred trees, but the crop is disposed of in local markets entirely. I have not been able to learn of the success of sweet cherries except in a limited way.

Charles A. KefFer, Knoxville.

Vermont: I :-Very limited extent, not sufficient to supply ten per cent of local consumption in larger cities.

2 :- Sour fairly well; sweet, not at all.

3:- - Sour. William Stuart, Burlington.

Wisconsin: We grow only two kinds of cherries, namely, Early Richmond and English Morello. We do not grow any sweet cherries at all. Practically no commercial cherry growing in the State. What few are grown are eaten by the birds before they are ripe.

E. P. SANDSTEN, Madison.

West Virginia: I :-Not very extensively. In some three or four sections of the state extensive orchards are now being planted.

2 :-Both reasonably well; the sour in the regions bordering on the Ohio River and Northern part of the State, while the sweet seem to thrive better on the higher grounds in the Southeastern portion of the State, especially in Greenbrier and Munroe counties.

3:-Local markets demand both sour and sweet cherries. The sour have been making more money for the grower than the sweet, although the sweet are coming into favour rapidly within the last few years. T. C. Johnson, Morgantown.

\section{CANADA}

British Columbia : I :-Cherries of a very superior quality are grown commercially in every part of the province.

2 :- Both sour and sweet succeed. Both in most parts; only the former in a few of the higheraltitudes.

3 :-Cherries that carry well are profitable, whether sour or sweet. Very late sour varieties are certainly profitable, perhaps even more so than the best sweet cherries when the markets are well stocked.

R. ANDERSON, Victoria.

Manitoba and Northwestern territories :-The cultivated cherries do not succeed. Sand Cherries do well. W. T. M. 
New Brunswick: 1 :- - To a limited extent.

$$
\text { 2:-Sour. }
$$

W. T. M.

Nova Scotia : I :-To a limited extent only. Nearly everyone has a few trees. General market limited.

2 :-Generally speaking, the sour cherries only, although the sweet are grown successfully to some extent in the Annapolis and Cornwalis Valleys.

3 :-Sour.

W. S. BLAIR, Nappan.

Ontario: 1 :- - Not very extensively for market.

2 :- Both succeed. The sweet are, however, limited to the more Southern parts of the province, and the sour to the South of Latitude $46^{\circ}$. 3 :-Sour.

W. T. M.

Prince Edward Island: I :-Only in a limited way for market, but sour cherries are abundant on the Island.

$$
\begin{aligned}
& 2:- \text { Sour. } \\
& 3 \text { :-Sour. }
\end{aligned}
$$

W. T. M.

Quebec : 1:-Very limited for market, but grown more extensively for home use.

2 :- - Sour. Succeed best near large bodies of water and especially along the St. Lawrence River.

3 :-Sour.

W. T. M. 


\section{LIST OF CHERRIES RECOMMENDED FOR CULTIVATION IN THE VARIOUS SECTIONS OF THE UNITED STATES AND THE BRITISH PROVINCES BY THE AMERICAN POMOLOGICAL SOCIETY}

\section{(Extract from Bulletin 8, Div. of Pomology U. S. Department of Agriculture)}

SUBSECTION 1 .-HEARTS AND BIGARREAUS.

[KEY.-Size, scale, $\mathbf{I}$ to $10 ; 1$, very small ; ro, very large. Form : c, compressed; $h$, heart shaped; 0 , oblate ; r, round. Color : a, amber ; b, black; p, purple ; r, red ; y, yellow. Quality : scale, r to ro ; r, very poor; ro, best. Season : e, e⿶rly ; m, medium; l, late; v, very. Use : d, dessert ; k, kitchen; $m$, market. Abbreviations of names of places of origin : Am., America ; Eng., England ; Eur., Europe ; Fr., France; Ger., Germany ; Ont., Ontario ; Rus., Russia.]

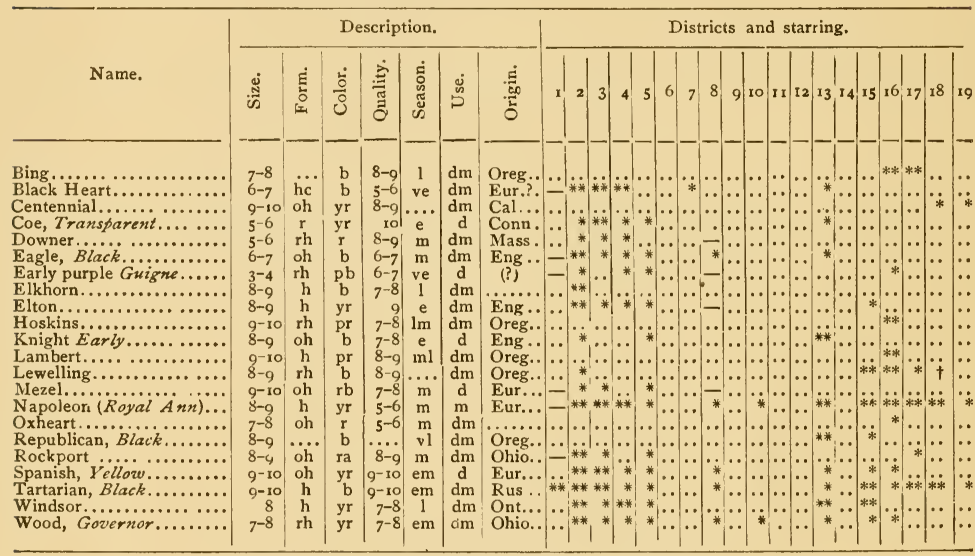

Subsction 2,--DUKE AND MORELLO CHERRIES.

\begin{tabular}{|c|c|c|c|c|c|c|c|c|c|c|c|c|c|c|c|c|c|c|c|c|c|c|c|c|c|c|}
\hline An & & $\mathrm{r}$ & & $7^{-8}$ & e & & Eur. & & & & & & & & & * & & $\cdots$ & & & $\cdots$ & & $\cdots$ & $\cdots$ & . & \\
\hline duke. & & of & $r$ & $7-8$ & em & $\mathrm{dk}$ & Eur... & & * & & $\cdots$ & .. & .. & $\ldots$ & - & & $*$ & $\cdots$ & .. & $*$ & $\ldots$. & .. & $\cdots$ & .. & .. & .. \\
\hline .. & 5 & J & $r$ & & 1 & $\mathrm{k}$ & Rus... & $* *$ & ** & $\ldots$ & .. & .. & .. & $\ldots$ & $t$ & $*$ & .. & .. & .. & $\cdots$ & .. & .. & $\cdots$ & .. & . & .. \\
\hline $\mathrm{Br}$ & & r & $r$ & $8-9$ & 1 & $\mathrm{k}$ & Eur .. & $* *$ & & & .. & . & .. & .. & $t$ & $*$ & .. & .. & $\ldots$ & .. & $\ldots$. & .. & .. & $\ldots$. & .. & . \\
\hline .. & & $\mathrm{r}$ & y & $4-5$ & $\mathrm{em}$ & k & Eur... & & * & & & & .. & $\ldots$ & $*$ & . & .. & $\cdots$ & .. & $\therefore$ & .. & $\cdots$ & $\because$ & .. & $\cdots$ & . \\
\hline ... & & $\mathrm{r}$ & I & 10 & e & . & Fr.... & . & $*$ & & $*$ & * & $\cdots$ &. & $*$ & $\because$ & $\because$ & $\cdots$ & $\ldots$ & $* *$ & . & $\because$ & $\because$ & .. & $\cdots$ & $\cdots$ \\
\hline e... & & ro & r & $5-6$ & ve & 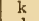 & $y \ldots$ & & k* & & $* *$ & $*$ &.. & $\cdots$ & $*$ & $\dagger$ & $*$ & $\cdots$ & $\cdots$ & $*$ & $\cdots$ & $\dagger$ & $\cdots$ & $\cdots$ & $\cdots$ & $\cdots$ \\
\hline$E n$ & & $r$ & $\mathbf{r}$ & $b-9$ & e & . & r.... & . & * & & $*$ & $\cdots$ & . & $\cdots$ & $\cdots$ & $\cdots$ & $\cdots$ & $\cdots$ & $\cdots$ & $* *$ & $\cdots$ & $\cdots$ & $\cdots$ & $\cdots$ & $\cdots$ & $\cdots$ \\
\hline e, $R e$ & & rh & $\mathrm{r}$ & $7-8$ & $\mathrm{ml}$ & $\mathrm{dm}$ & r.... & & *** & & 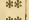 & & . & $\ldots$ & te. & & $\because$ & $\cdots$ & $\cdots$ & $* * *$ & $\cdots$ & $\because$ & $\cdots$ & $\cdots$ & * & $\cdots$ \\
\hline$\cdots$ & & ro & $\mathrm{r}$ & $7-8$ & em & $\mathrm{km}$ & r.... & * & $* *$ & $* *$ & $* *$ & $*$ & .. & $\cdots$ & & $* *$ & $*$ & .. & $\cdots$ & $* *$ & $\cdots$ & $*$ & $*$ & $\cdots$ & $\cdots$ & - \\
\hline Du & & oh & I & $6-7$ & 1 & k & g. & $\cdots$ & $* *$ & $*$ & $* *$ & * & $\ldots$ & $\cdots$ & & $\cdots$ & * & $\cdots$ & $\cdots$ & *** & $\cdots$ & ** & ** & $\cdots$ & $\cdots$ & $\cdots$ \\
\hline . & & $\mathbf{r}$ & $r$ & $4-5$ & $\operatorname{lm}$ & $\mathrm{k}$ & 1.?.. & $\ldots$ & $* * *$ & $* *$ & $\cdots$ & $\cdots$ & .. & $\ldots$ & $* *$ & $\because$ & $\because$ & $\cdots$ & $\cdots$ & .. & $\cdots$ & $*$ & *** & $\cdots$ & $\cdots$ & .. \\
\hline vka & & 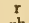 & $r$ & 45 & $\mathrm{em}$ & $\mathrm{k}$ & us .. & $* *$ & $* *$ & $\because$ & $\cdots$ & $\ddot{*}$ & $\cdots$ & $\because$ & * & $*$ & * & $\cdots$ & $\cdots$ & .. & . & . & $\cdots$ & $\cdots$ & $\cdots$ & $\cdots$ \\
\hline$\cdots$ & 7 & rh & $r$ & $6-7$ & 1 & k & Fr.... & & $*$ & $*$ & . & $*$ & $\cdots$ & $*$ & - & $\because$ & $\because$ & $\cdots$ & $\cdots$ & $\dot{1}$ & $\cdots$ & $\ddot{*}$ & $\dddot{*}$ & $\cdots$ & .. & $\cdots$ \\
\hline Du & & $\mathrm{rh}$ & $\mathbf{r}$ & $8-9$ & $\mathrm{e}$ & $\mathrm{dk}$ & Fr.... & $*$ & \%o* & $* *$ & ***; & * & .. & $\cdots$ & - & .. & $*$ & .. & $\ldots$ & 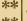 & $\ldots *$ & ** & $*$ & $\cdots$ & .. & $\cdots$ \\
\hline ; & & $=$ & $\mathbf{r}$ & $7-8$ & em & $\mathrm{km}$ & ... & 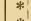 & $* *$ & $* * *$ & *** & $\because$ & $\ldots$ & $*$ & $* *$ & & $\because$ & .. & $\ldots *$ & $* *$ & & . & $\because$ & . & .. & \\
\hline lo, $E_{n}$ & & rh & $\mathrm{rb}$ & $5-6$ & 1 & $\mathrm{~km}$ & Eng.. & $*$ & $* *$ & * & $* *$ & $*$ & $\cdots$ & $\cdots$ & *** & $*$ & $*$ & $\cdots$ & $\ldots *$ & $* * *$ & $* * *$ & $* *$ & $*$ & $\cdots$ & .. & \\
\hline$\cdots$ & & $\mathrm{r}$ & r & 5 & e & $\mathrm{k}$ & I11... & $\cdots$ & & $=*$ & $\because$ & $\ldots$ & $\cdots$ & $\cdots$ & $\dagger$ & $\cdots$ & $\ddot{*}$ & $\cdots$ & $\cdots$ & $\because$ & $\cdots$ & & $\cdots$ & $\cdots$ & $\cdots$ & $\cdots$ \\
\hline$\cdots$ & & $r$ & $r$ & 6 & e & dk & Fr.... & $\because$ & $* *$ & $* *$ & $*$ & . & $\cdots$ & $\cdots$ & & $\because$ & ww & $\cdots$ & $\cdots$ & $*$ & $\because$ & $\begin{array}{l}t \\
*\end{array}$ & $\cdots$ & $\cdots$ & $\because$ & $\cdots$ \\
\hline & & e & $\mathrm{rb}$ & $6-7$ & $\mathrm{~m}$ & $\mathrm{dkm}$ & Rus .. & * & * & $\cdots$ & $*$ & . & $\cdots$ & $\cdots$ & $*$ & & $\cdots$ & $\cdots$ & $\cdots$ & $\ddot{*}$ & $\cdots$ & $*$ & $\cdots$ & $\cdots$ & - & $\cdots$ \\
\hline Lon & & $r$ & I & $5-6$ & e & $\mathrm{k}$ & Fr.... & * & * & $*$ & $\cdots$ & $\cdots$ & $\cdots$ & $\because$ & & $\cdots$ & $\cdots$ & $\because$ & $\because$ & $*$ & $\because$ & $*$ & $\because$ & $\because$ & $\cdots$ & $\cdots$ \\
\hline e $M$ & & rh & $\mathbf{r}$ & 5 & $\mathrm{~m}$ & & Am... & & $* *$ & 桬 & 注 & $\because$ & $\cdots$ & & & $\cdots$ & $\because$ & $\cdots$ & $\cdots$ & $* *$ & $\cdots$ & $\because$ & 永米 & $\because$ & $\cdots$ & \\
\hline $\mathrm{R}$ & & & $\mathrm{r}$ & & e & $\mathrm{km}$ & Eur .. & & $*$ & * & & & $\cdots$ & $\cdots$ & & $\cdots$ & & $\cdots$ & $\cdots$ & & $\cdots$ & $\because$ & & & - & . \\
\hline$\cdots$ & & rh & 1 & & el & $\mathrm{k}$ & Fr.... & & $*$ & 3 & $\cdots$ & $\cdots$ & $\cdots$ & $\cdots$ & $\cdots$ & $\ddot{t}$ & $\cdots$ & $\cdots$ & $\cdots$ & Ts & $\cdots$ & $\because$ & $\cdots$ & $\because$ & $\because$ & \\
\hline & & $\mathbf{I}$ & & & $\mathrm{m}$ & & Eur .. & $*$ & $\cdots$ & $\cdots$ & $\because$ & $\cdots$ & $\cdots$ & $\cdots$ & $\because$ & $\mathrm{T}$ & $\cdots$ & $\cdots$ & $\cdots$ & $\because$ & $\cdots$ & • & $\cdots$ & $\because$ & $\cdots$ & \\
\hline 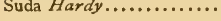 & & c & & $7^{-8}$ & 11 & d km & & $\cdots$ & $\cdots$ & . & T & - & $\cdots$ & $\cdots$ & $\mathrm{T}$ & $\cdots$ & $\cdots$ & & $\cdots$ & $\cdots$ & & .. & $\cdots$ & $\cdots$ & * & \\
\hline
\end{tabular}




\section{CHERRIES AT THE LOUISIANA PURCHASE EXPOSITION, ST. LOUIS, I904}

As the Cherry Committee was not organized until after the cherry season, it was not possible for the members of the Committee to examine the fruit on exhibition at St. Louis, but Prof. L. R. Taft, Chairman, Horticultural Department, Jury, was asked to furnish some information regarding the cherries exhibited at St. Louis, and he kindly consented to do so. Following is a copy of a letter received from Prof. Taft :

"While the records and entry cards show the varieties and quantities of cherries exhibited,together with the names and addresses of the exhibitors, I doubt if you would be able to get much from the records that would be of value to you. The quantity of sweet cherries exhibited was very small. Those from Oregon were best in every way. A number of large shipments were made and the fruit was of extra large size and came through in excellent condition. Several large exhibits were also made from Michigan; the best being from Paul Rose, of South Frankfort. The South Haven Sub-station made several shipments, and other exhibits came from Benton Harbor. Several fine boxes were also received from the Sacramento Valley, California. Napoleon and Black Tartarian were the leading varieties, although there were a number of fine shipments of Bing and Black Republican from Oregon.

For the most part, the sour cherries were of three varieties :-Richmond, Montmorency, and English Morello. Among the other varieties exhibited were :-Wragg, Magnifique, Montreuil, Olivet and Dyehouse. The largest exhibits of sour cherries came from Missouri, Kansas, Colorado, Nebraska, Iowa, Minnesota, Wisconsin, Illinois, Michigan, and New York.

From the fact that an exhibitor could have but one award, and that most of them showed several kinds of fruit, it would not be possible to give the names of those who received medals. I could furnish you with a list of the names of those who received medals upon cherries, but where a man exhibited four or five kinds of fruit, the award was made for 'an exhibit of fruit,' so that any list of awards upon cherries would be mis. leading. To tell everything about it, it would be necessary to examine the I 2, 000 entries.

Trusting that this will aid you, I am,

Yours very truly, L. R. TAFt." 


\section{CHERRY STATISTICS FOR THE UNITED STATES}

\section{Extracts from the Twelfth Census of the United States, i9oo}

The cherry ranks third in importance among drupaceous fruits. Cultivated cherries are of two classes: Morellos, the semi-hardy fruit grown throughout the temperate zone and Bigarreaus, or Hearts-the sweet cherries, successful in restricted localities only.

Table below shows the number of trees and bushels of cherries reported for the ro states in which that fruit was grown in greatest abundance in 1900 and $\mathrm{r} 890$.

Number of Cherry Trees and Bushels of Fruit Produced, i8go and igoo, in Io Specified States, With per cent of InCREase

\begin{tabular}{|c|c|c|c|c|c|c|}
\hline \multirow{2}{*}{ STATBS. } & \multicolumn{2}{|c|}{ TREBS. } & \multicolumn{2}{|c|}{ BUSHRL.S. ${ }^{X}$} & \multicolumn{2}{|c|}{$\begin{array}{l}\text { PER CBNT } \\
\text { INCREASE. }\end{array}$} \\
\hline & 1900 & 1890 & 1900 & 1890 & Trees. & Bushels. \\
\hline The United States. & $11,943,287$ & $5,638,759$ & $2,873,499$ & $1,476,719$ & III.8 & 94.6 \\
\hline Kansas........ & $1,109,673$ & $\mathbf{1}, 087,890$ & 60,5 II & 101,060 & 2.0 & 240.1 \\
\hline Pennsylvania ...... & 956,273 & 465,867 & 474,940 & 60,571 & $105 \cdot 3$ & 684.1 \\
\hline Indiana $\ldots \ldots \ldots$. & 896,641 & 617,168 & 228,485 & 199,939 & $45 \cdot 3$ & $14 \cdot 3$ \\
\hline Michigan......... & 895,375 & 447,334 & $194,54 \mathrm{I}$ & 150,526 & 100.2 & 29.2 \\
\hline Iowa............. & 791,327 & 199,067 & I 18,743 & 49,334 & $297 \cdot 5$ & 1407 \\
\hline Illinois.... . . . & 727,973 & 288,836 & 204,279 & 86,254 & 152.0 & 136.8 \\
\hline$\ldots \ldots \cdots$ & 697,270 & $368,3^{11}$ & 192,954 & $117,33^{\circ}$ & 89.3 & $64 \cdot 5$ \\
\hline California......... & 686,891 & 236,945 & 318,960 & 154,063 & 1899 & 107.0 \\
\hline Missouri & 679,985 & 381,185 & 62,708 & 88,444 & 78.4 & ${ }^{1} 29.1$ \\
\hline Nebraska......... & 607,017 & I 75,944 & 54,047 & 18,004 & 2450 & 200.2 \\
\hline
\end{tabular}

2 For years 1899 and 1889 .

2 Per cent of decrease.

All but 13 states show a gain in production, the ro showing largest gains all lying north of the thirty-seventh parallel.

The earliest plantings of cherries were in the region from Delaware to Tennessee, but probably the most extensive plantings at the present time are in a region of which St. Louis is the geographic center, and within a radius of about 400 miles. A decided increase is shown in the number of trees reported throughout the United States.

Table xvii gives the average number of cherry trees and of bushels of fruit per farm reporting. The District of Columbia, Colorado, and California, each reported a very large number of trees per farm. Colorado and California are the only states that are extensively engaged in growing cherries in commercial quantities. 
TABle XVII.-Average Number of Cherry Trees per Farm Reporting, June I, 1900, and Bushels of Fruit Produced in 1899, By States and Territories

STATES AND TERRITORIES.

The United States ........................

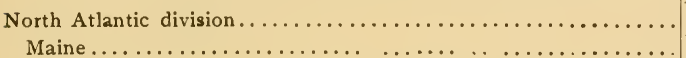

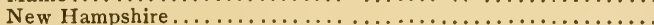

Vermont.

Massachusetts.

Rhode Island.

Connecticut.

New York.

New Jersey.

Pennsylvania

\begin{tabular}{|c|c|}
\hline $\begin{array}{l}\text { Trees } \\
\text { per } \\
\text { farm. }\end{array}$ & $\begin{array}{c}\text { Bushels } \\
\text { per } \\
\text { farm. }\end{array}$ \\
\hline 12.2 & 2.9 \\
\hline 10.6 & 5. I \\
\hline $5 \cdot 7$ & o 8 \\
\hline $4 \cdot 2$ & 0.7 \\
\hline 7.0 & 0.5 \\
\hline $4 \cdot 6$ & 1.6 \\
\hline 5.1 & 3.1 \\
\hline $5 \cdot 3$ & 3.2 \\
\hline I I. 3 & $4 \cdot 5$ \\
\hline 12.3 & 11.4 \\
\hline 10.8 & $5 \cdot 4$ \\
\hline 9.7 & $3 \cdot 7$ \\
\hline $\begin{array}{r}\text { I } 7.4 \\
8.0\end{array}$ & $\begin{array}{l}9.7 \\
6.9\end{array}$ \\
\hline 64.6 & $15 \cdot 5$ \\
\hline 10. I & 7.1 \\
\hline $\begin{array}{r}13.3 \\
8.2\end{array}$ & $\begin{array}{l}3.9 \\
1.6\end{array}$ \\
\hline $7 \cdot 9$ & 0.5 \\
\hline $7 \cdot 7$ & 0.4 \\
\hline 15.6 & 1.0 \\
\hline 12.2 & 2.1 \\
\hline 10.0 & 2.7 \\
\hline 9.2 & 2.4 \\
\hline 10.2 & 2.8 \\
\hline 13.8 & 2.9 \\
\hline 11.2 & 1.2 \\
\hline 9.9 & 0.5 \\
\hline 12.3 & 1.9 \\
\hline 99 & 0.9 \\
\hline 5.6 & 0.9 \\
\hline 17.1 & 0.7 \\
\hline 19.2 & 1.7 \\
\hline 20.3 & I. I \\
\hline 9.6 & 05 \\
\hline 7.9 & I. I \\
\hline 8. I & 0.4 \\
\hline 5.0 & 0.1 \\
\hline 5.2 & 0.4 \\
\hline 6.3 & 0.7 \\
\hline 74 & 0.4 \\
\hline 17.9 & 0.1 \\
\hline 85 & 0.6 \\
\hline 8.9 & 0.6 \\
\hline 31.0 & 10.3 \\
\hline 25.5 & I. 0 \\
\hline I I. 7 & $\left({ }^{x}\right)$ \\
\hline 66.9 & 2.8 \\
\hline 170 & $4 \cdot 9$ \\
\hline $7 \cdot 9$ & I. 5 \\
\hline 201 & 30 \\
\hline $9 \cdot 5$ & 0.5 \\
\hline 15.6 & 3.8 \\
\hline I5 9 & $3 \cdot 9$ \\
\hline 17.8 & $4 \cdot 9$ \\
\hline 80.9 & 37.8 \\
\hline
\end{tabular}

South Atlantic division

Delaware

Maryland...

District of Columbia

Virginia .

West Virginia

North Carolina.

South Carolina...

Georgia.

North Central division

Ohio.

Indiana.

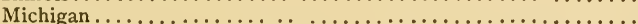

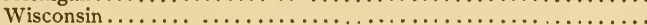

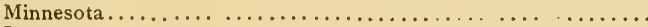

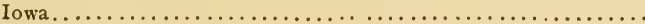

Missouri.

North Dakota

South Dakota

Nebraska. .

South Central division

Kentucky

Tennessee

Alabama.

Mississippi

Louisiana.

Oklahoma

Indian Territory

Arkansas.

Western division

Montana.

Wyoming

Colorado.

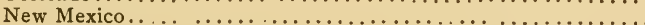

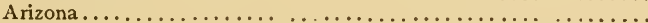

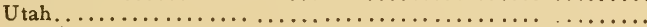

Nevada.

Idaho.

Washington

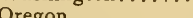

California. 


\section{CHERRY STATISTICS FOR CANADA}

(Extract from the Fourth Census of Canada, i9oi)

\begin{tabular}{|c|c|c|c|}
\hline & $\begin{array}{l}\text { Bearing } \\
\text { trees. }\end{array}$ & $\begin{array}{c}\text { Non-bearing } \\
\text { trees. }\end{array}$ & $\begin{array}{l}\text { Bushels } \\
\text { of fruit. }\end{array}$ \\
\hline 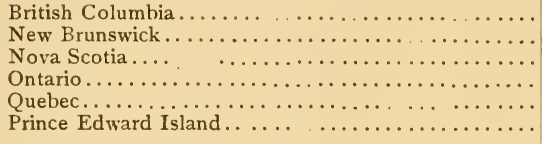 & $\begin{array}{r}17,322 \\
13,331 \\
43,153 \\
446,556 \\
317,762 \\
48,917\end{array}$ & $\begin{array}{r}10,890 \\
21,239 \\
18,883 \\
237,792 \\
76,328 \\
21,514\end{array}$ & $\begin{array}{r}14,439 \\
4,233 \\
16,669 \\
132,117 \\
150,690 \\
17,838\end{array}$ \\
\hline
\end{tabular}




\section{BIBLIOGRAPHY}

Compiled Mainly from Experiment Station Record Vol. I. No. i, I889,-Vol. XVI, No. 3, 1904

Cherries :

\section{CHERRIES}

Acids in :-(W. Keim, Zeitsch. f. analyt. Chem., 13).

Almond grafted on :-(L. Daniel, Rev. Gen. Bot., 6, 1894, No. 6r ). Analyses :-(W. Keim, Zeitsch. f. Chem. 13); (W. O. Atwater and C. D. Woods, Conn. Storrs Sta. Rpt., I89r) ; (G. E. Colby, California Sta. Rpt., 1895) ; (A. Girard, Bul., Min. Agr. France, 17, 1898, No. 7); (G. W. Shaw, Oregon Sta. Bul. 55); (A. D. Selby, Ohio State Hort. Soc. Rpt., I 898); (A. D. Selby and J. W. Ames, Ohio Sta. Bul. 1 27 ); (A. Ystgaard, Tidsskr. Norske Landbr., 9, 1902).

of Juices:-(Beiträge zur Kenntniss der chemischen Zusammensetzung reiner Fruchtsäfte, H. Kiremla.-Ztschr. Nahr. Untersuch. und Hyg., 7, 1893; Abs. in Chem. Ztg., 17, 1893 Report); H. Kremla, Ztschr. Nahr. Hyg. Waar., 7*; abs. Chem. Centbl., 1894, I., No. 24 ).

And plums, botany :-(C. E. Bessey, Rpt., Neb. Hort. Soc. 26, I895). As affected by unusual cold :-(F. S. Earle, Alabama Coll.Sta. Bul. 106). Ash Constituents :-(W. Keim, Zeitsch. f. analyt. Chem., I3).

Barbados, notes :-(Roy. Bot. Gard. Trinidad, Misc. Bul. 23); (L. C. Washburn, Florida Sta. Bul. 24).

Bird, ash content of leaves of :- (Grandeau and Flicke Ann. Chim. et Phys., 5, ser. 8, 1876).

Black,Composition of Juice:-(H. Kiremla, Beiträge Zur Kenntniss der chemischen Zusam-mensetzung reiner Fruchtsäfte. Ztschr. Nahr. Untersuch. und Hyg., 7, 1893; abs. in Chem. Ztg., 17, 1893! Notes, (S. B. Green, Minn. Sta. Bul. 24, 1892); V. K. Chestnut, U. S. Dept. Agr., Div. Bot. Bul. 20).

Blooming dates of :-(W.Greene,Iowa Hort.Soc. Rpt., I900); (J. W. Smith, Jour. Columbus Hort. Soc., 18, 1903, No. 4); (F. W. Card, A. E. Stene, Rhode Island Star Rpt., 1903); (J. Craig, Can. Expl. Farms Rpt., I 895).

Blossoming period as affected by climate :-(J.W. Smith, Jour.Columbus Hort. Soc., I 8 , igo3, No. 4).

Bud development :-(W. R. Lazenby, Jour. Columbus Hort. Soc., I 4 , 1 899 , No. 3 ).

Budding native stocks :-(J.Craig,Can.Expl. Farms Rpt., 1893, 1899).

Brandied :- (A. W. Tourgée, U.S. Dept. Com.and Labor Mo., Consular Rpts. 75, 1904, No. 284).

California, analyses :-(G. E. Colby, Cal. Sta. Rpt., 1895 ).

Catalogue of cherries growing at Agr. Exp. Sta., Ames Iowa :(Iowa Sta. Spec. Bul. Feb., 1903). 
Catalogue of cherries tested at Agassiz, B. C.:-Can. Exp. Farms, Bul. No. 3, Second Series, 1900).

Chemical composition of one year old wood according to the four cardinal points :-(R. Otto, Gartenflora, 50, 1901, No. 7).

Classification :-(I. H. Bailey and G. H. Powell, N. Y., Cornell Sta. Bul. 98) ; (L. H. Bailey, N. Y., Cornell Sta. Bul. No. 38, 1892); (L. H. Bailey and G. H. Powell, N. Y., Cornell Sta. Rpt., I895, rprnt. Bul. 98).

Cleaning before eating:-(B. E. Erlich, Arch. Hyg., 41, 1901, No. 2). Climatic limits :-( J. B. Reynolds, Ont. Agr. Coll. \& Expl. Farms. Rpt., I903).

Compass, self sterility of :-(R. S. Mackintosh, Amer. Gard., 22, 190 r, No. 340).

Composition of juice :- (Truchon and Martin-Claude,Am.Chem. Analyt, 6,1901 i.

Composition of wood :-(R. Otto, Gartenflora, 50, 1901, No. 7).

Crossing experiments :-(Wm. Saunders, Canada Expl. Farms. Rpts., I 897 ); (H. C. Price, Trans. Iowa Hort. Soc., 37, I902) ; (F. W. Card and G. E. Adams, Rhode Island, Kpt., I899).

Crude petroleum on :-(V. H. Lowe and P. J. Parrott, N. Y. Sta. Bul. 202).

Culture :-(J. L. Budd, Trans. Iowa Hort. Soc., 1893); (G. H. Powell, Delaware Sta. Rpt., I 897 , rprnt. Bul. 35 !.

and marketing:-(W. F. Massey, N. Carolina Sta. Bul. I 84). handbook :- E. Bartram, London and New York, John Lane, I 903). non success of at Southern Coast Range Substation :-(C. H. Shinn, Cal. Sta. Bul. I 4 I).

in California :-(B. M. Lelong, Cal. State Bd. Hort. Rpt., r 893 and I 894).

in Iowa :-(H. C. Price and E. E. Little, Iowa Sta. Bul. 73).

in Kansas:-(W. H. Barnes, Ka"sas State Hort. Soc., I900).

New York:-(L. H. Bailey and G. H. Powell, N. Y., Cornell Sta. Rpt. 1895, rprnt. Bul. 98) ; (Bul. 99).

South Dakota :-(N. E. Hansen, S. Dak. Sta. Bul. 8I).

West Indies :-(Agr. News, Barbados, 3, 1904, No. 48).

in pots :-(S. M. Emery Montana Sta. Bul. 24).

Diseases and Insects :

Disease of :-(M. C. Cooke, Jour. Roy. Hort. Soc., 26, I90 I, No. 2-3).

Aphis, notes:-( J. B. Smith, New Jersey Sta. Bul. 72, 189o; M. H. Beckwith, Delaware Sta. Rpt., I891; H. Osborn, Trans. Iowa Hort. Soc., 27, I 892 ; W. C. Sturgis, Connecticut State Sta. Rpt. I 894 ; C. P. Gillette, Colorado Sta. Rpt., I897; W. B. Barrow and R. H. Pettit, Michigan Sta. Bul. I60; H. Garman, Kentucky Sta. Bul. 80 ; V. H. Carpenter, reprnt. from Rpt. Council Roy. Dublin Soc. I 898 ; J. Fletcher, Canada Expl. Farms Rpts., 1897, 1898, 1902, 1903; N. Banks, U. S. Dept. Agr., Div. Ent., Bul. 34, n. ser; W. Lochead, Rpt. Ont. Ent. Soc., r9or ; California Bd. Hort. Rpt., I90I-2. (W. G. Johnson, Maryland Sta. Bul. 48).

Beetle, red :-(G. C. Davis, Michigan Sta. Rpt., I 896).

Black knot, notes :-(F. L. Scribner, Tennessee Sta. Bul. Vol IV. No. I, I89I) ; B. D. Halsted, New Jersey Sta. Annual Rpt., r89o; 
New York State Sta. Bul. 35, new ser., r89 i L. H. Pammel, Trans. Iowa Hort. Soc., I 893 ; J. Craig, Canada Expl. Farms Bul. 23 ; A. D. Selby, Ohio Sta. Bul. 79 ; H. H. Lamson, New Hampshire Sta. Bul. 48 ; C. S. Crandall, Colorado Sta. Bul. 5o ; W. A. Riley, Bul. Torrey Bot. Club, 27, I900 ; G. E. Stone, Massachusetts State Bd. Agr. Leaflet No. 3 ; F. C. Stewart, F. M. Rolfs, F. H. Hall, New York State Sta. Bul. I 9 I ; W. B. Alwood, Rpt. State Ent., Virginia, I90 I.

treatment :-(G. W. Churchill, New York State Sta. Ann. Rpt., I89o. E. G. Lodeman, New York Cornell Sta. Rpt., I 894, reprnt. Bul.8 I of Sta.).

Blight, notes :-(T. A. Williams, South Dakota Sta. Bul. 35, 1893).

Borer, description and treatment :

Branches, a new fungus on :- (F. C. Stewart, F. M. Rolfs, F. H.

Hall, New York State Sta. Bul. I9 I).

Brandy, examination:-(K. Windisch, Arb. Kais.Gesund. Amt.,II., abs, in Ztschr. angew. Chem., I 895).

Brown leaf spot, notes :-1 IV. B. Alwood, Virginia Sta. Bul. 24, r 893). rot, notes :- (W. H. Evans, New Jersey Sta. Bul. 91, I892.

Brown rot, spraying to prevent :- (J. Craig, Canada Expl. Farms Rpt., I 894).

Bug, notes :-(W. W. Froggatt, Agr. Gaz. N. S. W., 8, I 897 ).

Cladosporium cerasi:-(R.Aderhold Centbl.Bakt.U. par. 2.abt. 7, I90 I). description of:-(F. A. Waugh, Plums and Plum Culture, 1901).

Cryptosporium cerasinum:-(F. C. Stewart, F. M. Rolfs, F. H. Hall, New York State Sta. Bul. I9I).

Curculio, remedies:-(A. J. Cook, Michigan Sta. Bul. 38 ।.

Diseases :- (W. Carruthers, Jour. Roy. Agr. Soc. Eng., 62, I 901 ).

in the Hudson Valley :- (F. C. Stewart, and F. G. Blodgett, New

York State Sta. Bul. 67 ).

new :-(L. Pynaert, Tijdschr. Boomteelkunde, I 899).

notes on :-(A. L. Quaintance, Georgia Sta. Rpt., I900; E.

Marchal, Bul. Agr. Brussels, I 8, I 902 , No. 2 ).

Enlargements of branches :--(F. C. Stewart, F. M. Rolfs, F. H. Hall, New York State Sta. Bul. I 9 I).

Fly, development of :-(K. Sajo, Prometheus, I 4, 1902, No. 679). notes :- (K. Sajo, Prometheus, I2, I901, No. 614).

Fruit fly, notes:-1M. V. Slingerland, New York, Cornell Sta. Bul.

r 72 ) ; (F. H. Chittenden, U. S. Dept. Agr., Div. of Ent. Bul. 44). setting, a study of the conditions affecting :-(E. S. Goff, Wisconsin Sta. Rpt., I90 I).

Fungous enemies :-(F. L. Stevens, North Carolina, Sta. Bul. I 86).

Fusarium disease:-(R. Aderhold, Centbl. Bakt. U. Par. 2. Abt. 7 , I90 I).

Gnomonia erythrostoma:-(F. Corboz, Chron. Agr. Canton Vaud. I 4 , I90 I).

Gummosis:-(A. D. Selby, Ohio Sta. Bul. 79); (P. Passey Rev. Hort., Paris, I902, No. I I) ; (F. T. Brzezinski, Compt. Rend. Acad. Sci., Paris, 134, 1902, No. 20).

Gummosis investigations : - (F. T. Brzezinski, Compt. Rend. Acad. Sci. Paris, 134,1902 , No. 20 .

Hail injury :- F. C. Stewart, F. M. Rolfs, F. H. Hall, New York State Sta. Bul. r9 I). 
Hexenbesens, notes :- (F. C. Stewart, Garden \& Forest, 8, 1895 ; New York State Sta. Rpt., I 895 ; A. W. Borthwick, Trans. and Proc. Bot. Soc. Edinburgh, 2 I, I900).

prevention :-(K. Von Tubeuf, Prat. Bl. Pflanzenschutz, I, I 898). Hybrid, notes :-(L. H. Bailey, New York, Cornell Sta. Bul. 70).

Insects affecting :-(C. P. Gillette, Colorado State Bd. Hort. Rpt., I 90 I) ; (Sta. Bul. 7 r).

Insect enemies of the :-(C. P. Gillette, Colorado State Bd. Hort. Rpt., I 90 I ; F. Sherman, Jr., North Carolina Sta. Bul. I 86 ).

Industry in Delaware:-(G. H. Powell, Delaware Sta. Bul. 35).

Laurel, mannite and sorbit in :-(C. Vincent and Delachanal, Compt. rend., I I 4 ).

Leaf beetle, notes :-(W. B. Barrows and R. H. Pettit, Michigan Sta. Bul. I60; R. H. Pettit, Michigan Sta. Bul. 186 ; F. H. Chittenden, U. S. Dept. Agr. Div. Ent. Bul. 1 9, n. ser.).

Leaf blight as affected by sunlight, notes :-(B. D. Halsted, Bul. Torrey Bot. Club, 28, I 899 ; D. G. Fairchild, U. S. Dept. Agr. Div. Veg. Path., Bul. 6).

treatment :-(D. G. Fairchild, U. S. Dept. Agr. Div. Veg. Path. Jour. Mycology, Vol. VII., No. 3, I893; H. H. Lamson, New Hampshire Sta. Bul. 19 ; S. A. Beach, New York, State Sta. Rpt., I 893 , rprnt. Bul. 72 ; F. C. Stewart, F. M. Rolfs, F. H. Hall, New York State Sta. Bul. I9I).

Leaf scorch, notes :-(F. C. Stewart, New York State Sta. Bul. I62 ; F. C. Stewart, F. M. Rolfs, F. H. Hall, New York State Sta. Bul. I91 ; J. Percival, Jour. South-east Agr. Col. Wye, Eng. 1902, No. 2 ).

Leaf spot, fungicides for :-(R. Thaxter, Connecticut State Sta. Ann. Rpt., I890 ; L. H. Pammel \& G. W. Carver, Iowa Sta. Bul. 30). Notes:-(G. McCarthy, North Carolina State Bul. 92, 1893; S. A. Beech, New York State Sta. Bul. 98 ; H. Garman, Kentucky Sta. Bul. 8o; Müller-Thurgau, Jahresber. vers. stat. u. Schule, Wädensweil, 1897-98; Ohio State Bul. 143).

treatment :-(S. A. Beach, New York State Sta. Bul. I 7 ; F. H. Hall, New York State Sta. Bul. I 7 , pop. ed.; S. A. Beach, New York State Sta. Rpt., I 896).

Micro-organisms on surface of cherries :-(B. E. Ehrlich, Arch. Hyg., 4I, I90I, No. 2).

Monilia :-(Frank and Krüger, Gartenflora, 46, 1897, No. 1 5) ; (47, I 898 , No. 4) ; (Ztschr. landw. Ver. Hessen, I897, No. 3 I) ; (C. A. Keffer, South Dakota Sta. Rpt., I 890).

rate of growth:-(C. A. Keffer, South Dakota Sta. Bul. 29, I 89 I).

Monilia-like disease of sour :-(Aderhold, Ztschr., Pflanzenkrank, II, 1901, No. 2-3).

Powdery mildew :-

appendages :-(J. G. Sanders, Jour. Mycol., 8, 1902, No. 64). notes :-(T. A. Williams, South Dakota Sta. Bul. 35, I893; G. McCarthy, North Carolina Sta. Bul. 92, 1893; L. H Pammel, Trans. Iowa Hort. Soc., I 893 ; A. D. Selby, Ohio Sta. Bul. 79 ; C. S. Crandall, Colorado Sta. Bul. 50; Col. Sta. Rpt., I 898 ; L. H. Pammel, Iowa Sta. Bul. I 7 , 1892). 
Root killed at Ottawa :-(J. Craig, Canada Expl. Farms Rpt., I 896). Root rot, a rhizomorphic :-(E. M. Wilcox, Oklahoma Sta. Bul. 49). Rot, Gloeosporium :-(A. Osterwalder Centbl. Bakt. u. par., 2. Abt., II, 1903 , No. 6-7).

Sawfly, notes:-(T. A. Williams, South Dakota Sta. Bul. 48 ; E. A. Ormerod, Rpt. Observations Injur. Insects, Common Farm Pests, 1896, 2 oth. Rpt. London).

remedies :- (Jour. Bd. Agr., London, 6, 1899, No. 3).

Scab, notes :-(L. H. Pammel, Iowa Sta. Bul. 23 ; L. H. Pammel, Trans. Iowa Hort. Soc., I893; A. D. Selby, Ohio Sta. Bul. 79).

Scale :-(W. G. Johnson, U. S. Dept. Agr. Div. Ent. Bul. 6 ; J. Fletcher, Canada Expl. Farms Rpts., I 897 ; N. Banks, U. S. Dept. Agr. Div. Ent. Bul. 34, new ser.).

Selandria atra :-(R. Newstead, Jour. Roy. Hort. Soc., 26, 1902).

Shot-hole blight treatment :-(J. B. Smith and B. D. Halsted, N. J. Sta. Bul. 86).

Shot-hole disease, notes :-(A. D. Selby, Ohio Sta. Bul. 79) ; (W. Lochead, Ont. Agr. Coll. Rpt., 1902).

Slug, notes :-(C. M. Weed, Ohio Sta. Bul. 6, sec. ser., I889'; (F. H. Hillman, Nevada Sta. Bul. Io, I890); (H. Osborn, Dept. Agr., Div. Ent., Bul. 23, I891); (J. Fletcher, Canada Expl. Farms, Bul. I I, I891); (F. L. Washburn, Oregon Sta. Bul. I8, I892); (A. J. Cook, Michigan Sta. Rpts., 1890 and I891); (G. Coote, Oregon Sta. Bul. 34); (T. W. Kirk, New Zealand Dept. Agr. Leaflet No. I); (C. P. Lounsbury, Agr. Jour., Cape Colony, 9, r896); (C. L. Marlatt, U. S. Dept. Agr., Div. Ent. Cir. 26, sec. ser.); (J. Fletcher, Canada Expl. Farms Rpts., I 893, 1896, 1900); (F. H. Hillman, Nevada Sta. Bul. 36) ; (A. M. Lea, Agr. Gaz., Tasmania, 7 , 1900); (T. D. A. Cockerell, New Mexico Sta. Bul. 35); (A. M. Lea, Pub. Dept. Agr., Tasmania, 1902); (C. P. Gillette, Colorado Sta. Rpt., I902); (Weed, C. M., Ohio Agr. Exp. Sta. Bul. Vol. II No. 6, sec. ser., r 889 ).

Spot disease, notes:-(L. H. Pammel, Iowa Sta. Bul. I3, I891) ; (T. A. Williams, South Dakota Sta. Bul. 35, 1893); (L. H. Pammel Trans. Iowa Hort. Soc., I 893).

treatment :-(L. H. Pammel, Iowa Sta. Bul. 13, r891); (Bul. I7, 1892, Bul. 20, r893).

Sweet, injury in the Rhine provinces:-(P. Sorauer, Naturw. Wchnschr., 15, 1900, No. I2).

Tree disease, cause and prevention, Valsa leucostoma:-(R. A. Aderhold, Arb. K. Gesundheitsamte., Biol. Abt. 3, 1903, No. 4).

Tree metabolism :-(S. Aoyama, Imp. Univ. Col. Agr. Tokyo, B., Vol. 2 , No. 7).

Tree plant louse, notes :-(F. L. Harvey, Maine Sta. Rpt., I888); (C. M. Weed, Ohio Sta. Bul., Vol. I, No. 2, 1890 ).

Tree scallop shell moth, notes :-(J. H. Comstock, New York, Cornell Sta. Bul. 23, 1890 ).

Tree tortrix, notes :-(J. H. Comstock, N. Y., Cornell Sta. Bul. 23, 1890); (J. B. Smith, Div. Ent. Vol. V., No. 5 , 1893).

Webworm:-(T. D. A. Cockerell, New Mexico Sta. Bul. I9).

Winter forms of Monilia :-(Frank and Kruger, Cartenflora, 47, 1898, No. 4). 
Witches' broom :-(F. C. Stewart, F. M. Rolfs, F.H. Hall, New York State Sta. Bul. I9I).

Dried, glycerin content of :-(A. Schmid, Jahresber. Chem. Untersuch. Lab. Augsburg, I90 I).

Drying :-(Wurttemberg. Wchnbl, Landw., r9oo, No. 31); (J. Udale, Jour. Roy. Hort. Soc., 26, 1902).

Duration of growth period in trees :- (F. Cranefield, Wisconsin Sta.Rpt., I900).

Dwarf:-(C. E. Bessey, Nebraska Sta. Bul. 18.) ; (L. H. Bailey, N. Y., Cornell Sta. Rpt., I894, rprnt. Bul. 70); (S. T. Maynard, J. H. Putnam, and S. W. Fletcher, Mass. Hatch Sta. Bul. 44).

Fertilizer experiments :-(Barth-Colmar, Cartenflora, 48, 1899, No. 5); (Dent. Landw. Presse, 29, 1902, No. 29).

Fertilizer ingredients removed from the soil by :-(G. E. Colby, California Sta. Rpt., 1895).

Fertilizer tests with :-(A. T. Jordan, New Jersey Sta. Rpt., 1901).

Flower buds as affected by cold :--(E. S. Goff, Wisconsin Sta. Rpt., r 897 ) ; (Bul. 77 ).

as affected by late spring frosts:-(H. Müller-Thurgan, Ztschr. Pflanzenkrank, I0, 1900).

hardiness of :-(E. S. Goff, Wisconsin Sta. Rpt., I 899).

Flower development :-(E. S. Goff, Wisconsin Sta. Rpt., I899, I900). Flowering :- (Garden, 53, I898, No. 1367 ).

Foliage, injuries by arsenites:-(C. P. Gillette, Iowa Sta. Bul. Io, I 89o); (A. J. Cook, Michigan Sta. Bul. 53, I889).

Forcing :-(Jour. Hort., I 895, No. 2419); (S. M. Emery, Montana Sta. Bul. 24).

French v. American :-(A. W. Tourgée, U. S. Dept. Com. and Labor, Mo., Consular Rpts., 75, 1904, No. 284).

Frosts, spring, as affected by :- (H. Müller-Thurgan, Ztschr Pflanzenkrank, 10, 1900).

Fruit buds, setting of fruit :-(P. Evans, Missouri Fruit Sta. Bul. Io).

Fumigation with hydrocyanic acid gas :-(V. H. Lowe and P. J. Parrott, N. Y. State Sta. Bul. 202).

Fungicides for :-(S. T. Maynard, Mass. Hatch Sta. Bul. I 3, I89 I).

Germination of pollen :-(E. S. Goff, Wisconsin Sta. Rpt., r9or).

Grafted on American wild black cherry :-(Amer. Gard. 22, I901, No. $324)$.

Grafting :-(N. E. Hansen, Neb. Hort. Soc. Rpt., I895).

Growing in high altitudes :-(W. T. Macoun, W. S. Blair, S. A. Bedford, A. Mackay, T. A. Sharpe, Canada Expl. Farms Rpts., I 899).

Gum, organized ferment :-(F. Garros, Bul. Soc. Chim. de Paris, 7-8, I 892 , ser. 3 , Nos. I 5,16$)$.

Hardy, list of :- (J. Craig, Canada Expl. Farms Rpts., I 89o, I895; W. T. Macoun, I899).

Hardy stocks for:-(E. R. Lake, Oregon Sta. Rpt., I901).

Hybrid, notes :-Bailey, N. Y. Cornell Sta., Bul. 70.

Indian, notes :-(C. E. Bessey, Neb. Sta. Bul. I 8).

Injury in winter:-(F. R. Emerson, Nebraska Sta. Bul. 79).

Insecticides for:-(S. T. Maynard, Mass. Hatch Sta. Bul. No. I3, 1891); (J. B. Smith, New Jersey Sta. Bul. I 55).

Irrigation experiments :-(A. T. Jordan, New Jersey Sta. Rpt., 1900. 1902). 
Japanese, winter :--(Garden, 48, I895, No. 1255 ).

Juice, a chemical study of :- (Trouchon and Martin-Claude, Ann. Chem. Analyt, I901 ; Jour. Pharm. et Chim., 6 ser., 1901).

fermentation of :-(W. Keim, Zeitsch. f. analyt. Chem., I 3 ).

Mineral residues in sprayed :-(R.C. Kedzie, Mich. Sta. Bul. ror).

Montmorency, the :-(G. H. Powell, Amer. Gard., 22, 1901, No. 329).

Morello, as a bush tree :-(A. M. Garden, 48 , 1895, No. 1256).

Mulching to retard blossoming :- (J. Craig, Canada Expl. Farms Rpt., I 8,6$)$.

Notes :-(E. S. Goff, Wisconsin Sta. Rpt., 1896); (C. H. Shinn, California Sta. Rpt., 1895-1897); (W. C. Stubbs, F. H. Burnette, and E. Watson, Louisiana Stas. Bul., 52, 2 ser.) ; (E. S. Goff, Wisconsin Sta. Rpt., I897); (F. A. Waugh, Amer. Gard., 20, 1899, No. 220) ; (C. H. Shinn, California Sta. Rpt., r898).

Orchard enemies in the Pacific North-west :-(C. V. Piper, U. S. Dept. Agr., Farmers' Bul. 1 53).

notes :-(C. F. Austen, Alabama Coll. Sta. Bul. I I 7).

Orchards of Kent, a serious disease in the :-(W. Carruthers, Jour. Roy. Hort. Soc., I901).

Peach, grafted on :-(L. Daniel, Rev. Gen. Bot. 6., I 894).

Preparation for market:-(L. H. Bailey and G. H. Powell, New York, Cornell Sta. Bul. 98).

Propagation :-(J. Craig, Canada Expl. Farms, Bul. I 7); (W. N. Barnes, Kansas State Hort. Soc., I900); (H. C Price, and E. E. Little, Iowa Sta. Bul. 73).

Protection from birds :- (H. C. Price and E. E. Little, Iowa Sta. Bul. 73 ).

Prune, grafted on :-(L. Daniel, Rev. Gen. Bot. 6., r894).

Red :-composition of juice :-(Beiträge zur Kenntniss der chemischen

Zusammensetzung reiner Fruchtsäfte. H. Kiremla-Ztschr, Nahr

Untersuch. und Hyg., 7, 1893; abs. in Chem. Ztg., 1 7, 1893).

notes :-(R. C. Kedzie, Michigan Sta. Bul. ro I).

Wild as stock for cherries :-(J. L. Budd, Iowa Sta. Bul. I0, I890).

Retarding blossorning period :-(W. T. Macoun, Canada Expl. Farms Rpt., I 899).

Ripe or bitter rot :-(M. A. Cobb, Agr. Gaz. N. S. W., I4, I903, No. 7).

Ripening :-(W. Keim, Zeitsch. f. analyt. Chem., I3).

Rocky Mountain dwarf :-(N. E. Hansen, Proc. Soc. Prom. Agr. Sci., I go4).

the possibilities of the Western :-(N. E. Hansen, Proc. Soc. Prom. Agr. Sci., 1904).

Russian, culture in the Northwest :-(H. C. Price, Jour. Columbus Hort. Soc., 18 , 1903 , No. 4).

notes :-(R. C. Kedzie, Michigan Sta. Bul. I о ) ; (U. P. Hedrick, Michigan Sta. Bul. I 23 ; Rpt., 1895).

varieties :-(S. B. Green, Minnesota Sta. R. I 888).

Salicylic acid in :-(F. W. Traphagen, Montana Sta. Bul. 38).

Salicylic acid :- non existence in fruit stalks (H. Mastbaum Chem. Ztg. 27,1903 ). 
Sand :-- (S. B. Green, Minnesota Sta. Bul. 72).

breeding :-(N. E. Hansen, Iowa Hort. Soc. Rpt., 1900).

crossing :-(Wm. Saunders, Canada Expl. Farms Rpts., r896, r 897). culture:-(C. A. Keffer, South Dakota Bul. 26).

descriptive notes :-(S. B. Green, Minnesota Sta. Bul. I 8 ; C. E. Bessey, Nebraska Sta. Bul. I8; L. H. Bailey, Cornell Sta. Bul. 70 ). for redemption of sandy tracts :-(L. H. Bailey, Cornell Sta. Bul. 70). for shade between forest trees :- (S. A. Bedford, Canada Expl. Farms Rpts., r 898) ; W. T. Macoun, Canada Expl. Farms Rpts., I 899. for stocks :- (J. L. Budd, Iowa Sta. Bul. Io; J. L. Budd and N. E. Hansen, Iowa Sta. Bul. No. 22, Bul. No. 28); (J. Craig, Canada Expl. Farms Rpts., I895 ; N. E. Hansen, Garden, 65, I899, No. I 450).

hybrid with wild plum :-(Wm. Saunders, Canada Expl. Farms Rpts., I 897$)$.

notes :--(S. A. Bedford, Canada Expl. Farms Rpts., I 893 ; J. Craig, Canada Expl. Farms Rpts., I894; S. A. Bedford, A. MacKay, Canada Expl. Farms Rpts., I 894, I 895, I896, I 897, I898, I 90 I ; Thos. A. Sharpe, Canada Expl. Farms Rpts., I 895 ; Wm. Saunders, Canada Expl. Farms Rpts., I 896).

improvement :-(J. Craig, Canada Expl. Farms Rpts., I 896). in cultivation :-(R. A. Emerson, Agr., Neb., I, 1902, No. 6). on plum stocks:-(J. Craig, Canada Expl. Farms Rpts., I895, 1896). Seedlings at Agassiz, B. C.:-(Thos. A. Sharpe, Canada Expl. Farms Rpt., 190I).

at Indian Head, N. W. T.:-(Angus MacKay, Canada Expl. Farms 1898, 1898, 1899, 1900, 1901 ).

at Brandon, Man.:-(S. A. Bedford,Canada Expl. Farms Rpts., I897, I988).

Self-sterile varieties :-(S. W. Fletcher, N. Y., Cornell Sta. Bul. 18r). Setting of fruit :-(P. Evans, Missouri Fruit Sta. Bul. Io).

of fruit as affected by vigor of terminal bud :-(E. S. Goff, Wisconsin Sta. Rpt., I901).

Shot-hole, effect of :-(B. M. Duggar, Proc. Soc. Prom. Agr. Sci., I 898). fungus on fruit pedicels:-(F. C. Stewart and H. J. Eustace, New York State Sta. Bul. 199).

Sod versus cultivated :-(S. H. Fulton, Michigan Sta. Bul. I 87).

Sour, the, of America :-(G. H. Powell, Delaware Sta. Rpt.. I900). varieties :-(U. P. Hedrick, Utah Sta. Bul. 64).

Spraying :-(B. T. Galloway, U. S. Dept. Agr., Farmers' Bul. 38). effect on foliage:-(J. Craig, Canada Itxpl. Farms Rpt., I 892). for San José Scale with sulphur washes :-(C. V. Piper and R. W. Thatcher, Washington Sta. Bul. 56 ; P. J. Parrott, S. A. Beach, and H. U. Woodworth, New York State Sta. Bul. 247).

Stocks :-(J. L. Budd, Iowa Sta. Bul. Io, I89o ; E. S. Goff, Wisconsin Sta. Bul. 77 ).

hardy, for:-(E. S. Goff, Wisconsin Sta. Bul. 77).

Stone oil as an adulterant of olive oil :-(C. Micko,-Zeitsch. österr. Apoth. Ver., 31. Abs. in Analyst, June, I 893).

Sugar in: - (W. Keim, Zeitsch. f. analyt. Chem., 13).

Top grafting in Iowa :- (H. C. Price and E. E. Little, Iowa Sta. Bul. 73). 
Trees, analyses :-(P. Collier, New York State Sta. Rpt., I 89 I $)$.

duration of growth period in :-(F. Cranefield, Wisconsin Sta. Rpt., I900).

Utah hybrid :-(L. H. Bailey, New York, Cornell Sta. Bul. 70).

Varieties :-

Alabama :- J. Clayton, Sta. Bul. 47) ; (C. F. Austin, Sta. Bul. I17).

Canada :-(W. W. Hilborn, Canada Expl. Farms, Ottawa, Rpt., I 889); (J. Craig, Expl. Farms Rpt., r89o) ; (S. A. Bedford, Expl. Farms Rpts., r 890, I 893, ); (T.A. Sharpe, Expl. Farms Rpts., I 890, I893 I 895, I 898); (J. Craig, Expl. Farms, Bul. I 7) ; (W. T. Macoun, Expl. Farms Rpt., r $89^{8}$ ) ; (Wm. Saunders and T. A. Sharpe, Expl. Farms Bul. 3., Ser. 2).

California :-(C H. Shinn, Sta. Rpt., r 89 I-92) ; (B. M. Lelong, State Bd. Hort. Rpt., I893-94) ; (Sta. Rpt., I893-4) ; (A. V. Stubenrauch, Sta. Rpt., I902-3).

Colorado:-(H. H. Griffin, Sta. Rpt., I 890) ; (F. A. Huntley, Sta., Rpt., I892) ; (C. S. Crandall, Sta. Rpt., I896) ; (B. K. Blinn, Sta. Rpt., I 896).

Delaware :-(G. H. Powell, Sta. Rpt., I900; Sta. Bul. 35).

Georgia :-(G. Speth, Sta. Bul. No. I I); Gard. Chron., 3 ser. 34, 1903, No. 864 ; Garden \& Forest, B. D. Halsted, 8, 1895 .

Illinois :-(Agr. Exp. Sta., I 888) ; (T. J. Burrill and G. W. McLuer, Sta. Bul. No. 2 I).

Indiana :-(J. Troop, Sta. Rpt., 1896$)$.

Iowa :-(J. L. Budd, Sta. Bul. Nos. Io, I9, 3I) ; (H. C. Price and E. E. Little, Sta. Bul. 73).

Kansas :-(W. H. Barnes, State Hort. Soc., 1900).

Louisiana :-(H. A. Morgan and F. H. Burnette, Sta. Bul. No. 22. sec. ser.).

Maine :-(F. L. Harvey, Sta. Rpt., r889) ; (W. M. Munson, Sta. Bul. 6).

Massachusetts :-(S. T. Maynard, Hatch Exp. Sta. Buls. 4, 52, 104, I I 8; Stat. Rpt., r898); G. E. Stone, Massachusetts Agr. Col. Rpt., I 894 .

Michigan :-(T. T. Lyon, Sta. Buls. 55, 67, 80, 88, I 29, I 43, I 52 , I69); (L. R. Taft, Sta. Buls. I05, r68, r69, Sta. Rpt., I897); (L. R. Taft and S. H. Fulton, Sta. Bul. I 77); (S. H. Fulton, Sta. Buls. 187, 194) ; ('T. A. Farrand, Sta. Bul. 205) ; (L. M. Geismer and C. D. Smith, Sta. Spec. Bul. No. 20) ; (L. R. Taft and M. L. Dean, Sta. Bul. 2 I 3 ).

Missouri :-(J. W. Clark, Sta. Bul. Io).

Montana :-(S. M. Emery, Sta. Buls. 20, 24,28 ) ; (R. W. Fisher, Sta. Rpt., I902).

New Hampshire :-(F. W. Rane, Sta. Buls. 59, I05).

New Jersey :-(A. T. Jordan, Sta. Rpt., I go I).

New Mexico:-(F. Garcia, Sta. Bul. 39).

New South Wales :-(W. F. Allen, Agr. Gaz. I3, I902, No. 5 ).

New York, Cornell :-(L. H. Bailey and G. H. Powell, Sta. Bul. $9^{8}$; reprint Rpt., r895).

New York State :-(G. W. Churchill, State Sta. Rpt., I889); (C. E. Aunn, Sta. Rpt., r89o) ; (S. A. Beach, W. Paddock, and C. P. Close, Sta. Rpt., I 896); (S. A. Beach, New York Sta. Bul., 98); (S. A. Beach, N. Y. State Sta. Rpt., I 896 ; F. C. Stewart, F. M. Rolfs, and F. H. Hall, New York State Sta. Bul. I9 I). 
North Carolina :-(IV. F. Massey, Sta. Buls. 72, 92); G. McCarthy, North Carolina Sta. Bul. 22, I 893 .

Ohio :-(H. C. Price, Jour. Columbus Hort. Soc., I8, I903, No. 4); Ritzema Bos, Tijdschr. Plantenziekt, 2, 1896; A. D. Selby, Ohio Sta. Bul., 79 .

Oklahoma :-(O. M. Morris, Sta. Bul. 43, Sta. Rpt., I900, I901) ; J. Fields, Sta. Rpt., 1899).

Ontario, Canada :-(L. Woolverton, Ont. Dept. Agr, Rpt., I 898 ; Ont. Fruit Exp. Stas. Rpts., i 898, I 899, I 902).

Oregon:-(G. Coote, Sta. Bul. No. 34).

Pennsylvania :-(G. Hiester, Dept. Agr. Bul. No. ro6).

Rhode Island :-(L. F. Kinney, Sta. Bul. No. 7).

South Dakota :-(N. E. Hansen, Sta. Bul. 76).

Tennesee :-(C. S. Plumb, Sta. Rpt., I888) ; (R. L. Watts, Sta. Bul. No. 5 , Bul. Vol. V., No. I).

Texas :-(S. A. Beach. Sta. Bul. 16).

Utah :-(E. S. Richman, Sta. Buls., 18, 25, 37, 45) ; (U. P. Hedrick, Sta. Bul. 64) ; (State Bd. Hort. Bul. 9).

United States, Department of Agriculture :-(S. B. Heiges, Rpt. Pomologist, 1895) ; (Div. Pomology, Bul. 8).

Vermont :-(Rpt. of Director, Agr. Exp. Sta. I 888) ; (C. W. Minott, Sta. Rpt., 1889) ; (F. A. Waugh, Sta. Rpt., 1899).

Virginia :-(W. B. Alwood, Sta. Buls. 24, 65, 1 29, I33).

Water content of foliage and twigs :-(W. R. Lazenby, Proc. Soc. Prom. Agr. Sci., 1902).

Western dwarf, notes :-(L. H. Bailey, N. Y., Cornell Sta. Bul. 70).

White, notes :-( R. C. Kedzie, Michigan Sta. Bul. 10I).

White washing to prevent swelling of the buds :-(W. T. Macoun, Canada Expl. Farms, Rpt., I 899).

Wild, black knot, notes :-(B. D. Halsted, Forester, 2, 1896, No. 3). leaf spot :-(G. E. Stone and R. E. Smith, Massachusetts, Hatch Sta. Rpt., 1897); C. A. Keffer, S. D. Sta. B. 15, 1889; B. 20, 1891 ; B. 23 , 1891 ; C. E. Bessy, Neb. Sta. B. 18.

poisonous properties of the leaves:-(F. W. Morse and C. D. Howard, New Hampshire Sta. Bul. 56) ; (U. S. Dept. Agr., Farmers' Bul. 1०3).

Wine, preparation :-(W. Kelhofer, Jahresber. Vers. Stat. U. Schule, Wädensweil, 1899-1902).

Winter killing at Brandon, Man.:-(S. A Bedford, Canada Expl. Farms Rpts., I 895, 1897).

killing at Ottawa, Ont.:-(J. Craig, Canada Expl. Farms Rpts., 1896; W. T. Macoun, 1898$)$.

killing at Nappan, N. S.:-(W. S. Blair, Canada Expl. Farms Rpts., 1897).

Wood ash analyses :- R. Harcourt, Ont. Agr. Coll., Rpt., I897). 


\title{
PRESENT TREND OF PEAR GROWING
}

\author{
J. B. Cornell, Newburgh, N. Y.
}

With the great and increasing development in the field of Pomology naturally there should be and are numerous changes in varieties, many of the old standards being eliminated and newer and more desirable ones taking their places. In the case of pears, we meet with almost an exception in the whole line of fruits, for outside of the introduction of the Orientals, the great commercial varieties of today, are varieties that were produced nearly a century ago, while hundreds of new ones have been introduced. We have failed as yet to supplant in popular estimation the Bartlett, Seckel and Bosc. While no one would have the temerity to assert that we have reached the limit of perfection in the pear, we will have to admit that little progress has been made in many years. Our greatest innovation was the introduction of the Kieffer Pear a few years ago ; this pear had a more marked effect on commercial pear culture than any variety that has ever been introduced. It has been very extensively planted in pear growing sections east of the Rocky Mountains. Its popularity has been so great that in the last ten or fifteen years there is little doubt that more of them have been planted than of all other varieties combined. Many growers who have been located in the vicinity of canning factories have found this the most profitable of the whole list. For the past few years the general markets have been overburdened with this variety much of which has sold for ruinous prices. Evidently we have passed the limit of profitable production on this class of stock, whose value is for canning and culinary uses only. There is little or no planting of this variety in this section at present. I think growers of this century, are more alive to the requirements of the markets and the trend is more toward the production of high class fruit. The destructive effects on orchards of the severity of the winter of $1903-4$ seems to be more largely confined to the valley of the Hudson River. Here it was wide spread and disastrous. It has given a set back to commercial pear culture in this district that the next generation will hardly see repaired. Many orchardists who lost their pear trees are replanting the ground with apples and other fruits.

It seems to be the censensus of opinion that for several years past the planting of pears has not kept place relatively with other orchard fruits and this applies with especial force to the high grade varieties. With largely increased demand for choice pears one would think that there was little fear of over production for many years to come. 


\section{Leading Mariet Varieties Bartlett Leads}

This brief review of some of the characteristics of the leading market varieties, is, as I have seen them in this section of the state, and when market value is mentioned New York City Market is considered. In order of importance and popularity of the higher grade of pears, the Bartlett easily takes first rank commercially. Its good qualities are generally recognized and need not be mentioned, but I will note some of its weak points in the orchard. The tree seems to lack constitutional vigor owing probably to its deficient root system. It has a great tendency to overload with fruit and great susceptibility to the ravages of blight and Psylla when they are prevalent. With the careful cultivator some of these difficulties are overcome, by others only partially so.

Seckel : this ranks second in importance as a commercial fruit and is a favorite with the fruit canning public, who appreciate quality. In marked contrast with Bartlett it makes a strong vigorous tree, many old trees reaching great size. In habit of bearing in the orchard it closely resembles the Baldwin apple having pretty regularly its off seasons. I have found by special heavy fertilization this is overcome to a large extent. My experience with this variety in quite a large way leads me to the opinion that it is not a great success on heavy clayey soils. I know of no variety so susceptible to attacks of the codling moth as this owing to its habit of growing the fruit in clusters.

Bosc : While this is an old variety, it has only recently assumed much importance as a commercial sort. Its superior quality and attractive appearance when in perfection are adding every year to its laurels in the markets. The tree, being such a poor,irregular grower when young, almost necessitates the top working on some strong growing sorts, will not succeed on Angouleme with me and reports are also unfavorable when top worked on the Kieffer. I have a few top worked on this, and so far are doing well-too soon yet to form an individual opinion. Under good care I find this variety fairly productive but it is not a fruit for slipshod cultivators. After this variety reaches some age the trees develop much vigor and great hardiness having passed through last winter with little injury while adjacent Bartlett trees were largely killed.

Clapp : is practically the earliest maturing variety that growers are giving any attention to. Its great beauty added to its fairly good quality has made it desirable for market purposes. A tendency to rot at the core if left too long on the tree and great susceptibility of the tree to blight are its only drawbacks.

Clairgeau : is growing more in favor in the markets each recurring season while a pear of only fair quality in comparison with the Seckel and Bosc its size and appearance count for much. When properly handled and 
ripened it develops into a fruit of much excellence. Its short thick stem in connection with its large size renders it very liable to be thrown to the ground in wind storms which is a serious objection in many sections. Growth of tree and productiveness are all that could be desired.

Anjou : This has been a very much lauded pear for market in years past. While a grand fruit and deserving a place in every collection, it has been a disappointment for commercial purposes in this section at least. It possesses more weak points than any variety seeking commercial honors that I am familiar with. While the tree is a strong vigorous grower I have found it a very unreliable producer. Rarely failing to bloom profusely weather conditions have to be ideal for it to set fruit. Owing to a very tender skin the fruit has suffered much from sun scald and a moderate wind often brings a large percentage of them to the ground; and in addition to this it is not over popular in the markets.

Flemish Beauty, Sheldon, Tyson, Buffum, Lawrence, Angouleme, Louise Bonne, and some others, that at one time were commercial varieties in this district, have been virtually eliminated from the list. Flemish Beauty retains its old time popularity in some sections, notably Central and Northern New York and Mr. F. E. Dawley informs me that more of this variety is sold in the Syracuse market than of any other. He says this variety succeeds remarkably well there and is more largely grown than any other. Angouleme as a dwarf is grown to quite an extent in Western New York commercially. Neither of these two are of any value in this section under the best of conditions. I have never been able to find a satisfactory market for winter pears, but where such is to be had Josephine and Nelis are desirable. The Nelis is a pear of great excellence ranking in quality among the winter varieties with Seckel among the autumn ones. I believe the near future will see greater popularity for it.

\section{New VARIETIES}

Of the newer varieties that have been tested I know of only one so far that we can say with much confidence is an acquisition : that is the Worden-Seckel. The tree is a strong vigorous grower and a prolific bearer, when the tree reaches a little age. Some growers complain of it being a little shy in producing on young trees but my experience in top working it on old trees, show it to be very prolific and also the quality of the fruit is better than on young trees, which is not infrequent with some other varieties. I have failed so far to find a weak point with this new comer although some may develop later. The fruit is very much larger than the old Seckel and more attractive in appearance, in fact it is the most beautiful pear I know of. Its season of ripening is about that of Seckel. It is a superior keeper and in quality it ranks high, close up to its parent.

In New York market this season it sold for fancy prices. 
Mr. Geo. Sweet reports favorably on the quality of the Rossney but is not prepared as yet to recommend it for commercial planting.

Doyenne De Comice, as it comes from the Pacific Coast is very desirable ; while this is not a new variety, it is new to most growers. I recall seeing it grown successfully in a small way many years ago on the old homestead; also on the trial grounds of the late Chas. Downing. So far I find the tree a good grower and hardy, but it has not fruited. Size of fruit, season of maturity (Uct.) and superior quality of fruit would seem to make it worthy of extensive trial. Wilder ripening about the season of the Tyson is not equal to it in quality and is not promising commercially.

\section{Amateur Varieties}

In the amateur list we should certainly include the Elizabeth ; ripening a little ahead of the Tyson is a good companion to it. Although of small size its quality commends it. The best early reliable pear I have tested. I look on the Tyson as the hardiest, most vigorous variety in the whole list. A tree that grows and produces fruit under the most adverse conditions--neither blight, insects (San José Scale excepted) or arctic weather can overcome it. I know of neglected orchards where all other varieties have practically succumbed to adverse conditions except this. This variety was planted for commercial purposes in this section a few years ago but has been supplanted by Clapps which is superior to it only in size and appearance.

Lawrence : This is a variety that is still recommended by some pomologists for market and amateur purposes. It might be desirable where the pear midge is unknown, but where this insect is in evidence this variety would better be omitted from the list. It is a remarkable fact that the midge will practically destroy the fruit of this particular variety every season while other varieties in the same orchard are only slightly affected. And as yet we are without remedy.

Dana's Hovey should have more attention from the amateur who loves good fruit. A good grower and producer, matures late, and is a pear of the highest quality. Is said to be popular in the Boston market.

Gris d'Hiver, an old variety but little known at the present time, is a handsome late fruit of good quality and is well worthy of a place in the amateur list.

There is a long list of good pears of the old varieties that have been overshadowed by some of the over-praised new ones, that are not really acquisitions. But space forbids extension of the list further. 


\section{REPORT ON PLUMS}

Committee-F. A. Waugh, U. P. Hedrick, C. L. Watrous, J. W. KERR

The plum crop of 1904 was generally of extra quantity and quality. This was especially true of New England. A few sections had short crops or none at all, due to late frosts. This was the case in certain localities in western New York.

General Changes. Important changes have been going on in the standing of the different classes of plums, although no such revolutionary occurrences as the introduction of the Japanese varieties a few years ago. The most important of these changes relate to the localization of the different classes and varieties. Further experience shows with increasing clearness that varieties which succeed in one section may be second rate or worthless in another and that each locality must work out for itself the list of varieties best adapted to it. In a general way it has been pretty well demonstrated that Americana plums are best for Iowa, Wisconsin, Minnesota, and the neighboring states; that Domestica plums and the Damsons are best for southern Michigan, New York State, Massachusetts, and Connecticut. Plums of the Hortulana class appear to be the most profitable (coming into competition only with Japanese varieties) in southern New Jersey, Delaware, and the Maryland peninsula. Many localities in the central and south central states promise to be best suited by the new hybrids of the Gonzales group, combining the parentage of Japanese and Hortulana varieties.

The Japanese varieties continue to be largely planted over a wider range of country than ever before. Their popularity in the more important plum growing sections, however, is undoubtedly on the wane. In western New York particularly they are now held in light esteem. The popularity of the Japanese varieties is due to the ease with which they grow, the earliness with which they come into bearing and their prolificacy. In the sections where the Domestica varieties succeed, however, the Japanese varieties compare unfavorably with them in the points of hardiness, longevity, and quality of the fruit.

Particular Varieties. No new varieties of very great importance have become established in the horticultural field during the last few years. There are several promising sorts, particularly among the Gonzales group, referred to above, which, however, are suitable only for middle or southern latitudes.

The Wickson plum has waned in favor. It has been found that the tree comes late into bearing and ceases to bear well after it reaches a mod- 
erate age. It is tender in fruit bud and generally unreliable. The fruit is showy and sometimes of good quality when well ripened, but it ripens unevenly and can seldom be shipped to market with any profit.

Shiro and Apple are the most promising of the recent Burbank introductions and are receiving favorable reports from various sources.

Waugh, a plum of the Japanese Hortulana group, has given good results in the few places where it has been tested.

Climax, though highly advertised, has not found any important place in the eastern states. Most growers who have tested it, have already discarded it. A few have found it worth retaining in their collections, though no one has recommended it for a commercial plum. In this respect it has been a considerable disappointment, for at the time of its introduction there seemed to be good reasons for hope that it would take a place in the market list.

A number of new varieties of the Domestica class originated or collected by Mr. W. W. Dunlop of Montreal, have recently been named by the Quebec Pomological Society, and are now being disseminated in a smal way. The most promising of these seem to be Raynes, Mount Royal, and Dunlop. Descriptions of these varieties are not at hand but may be found in the Quebec Horticultural reports.

Three new varieties, Togo, Oyama, and Welcome, originating at the Central Experimental Farm, Ottawa, Ontario, were sent in for examination during the year. These all seem to be superior as regards the fruit. Descriptions of these varieties prepared by Mr. W. T. Macoun follow herewith :

Togo: Form roundish, somewhat heart shaped; size above medium; cavity narrow, medium depth, abrupt ; suture an indistinct, sometimes distinct line, no depression; apex slightly flattened; color deep red; dots numerous, small, indistinct; bloom moderate, bluish; skin yellow, moderately thick, tough; flesh yellow, firm, juicy; stone medium size, oval, slightly flattened, cling; flavor sweet, good, acid next skin; quality good. A promising plum. Larger than Red June and better in quality. Handsome. Named Togo August 3 Ist, 1904, in honor of Admiral Togo. Hybrid group. Originated at Central Experimental Farm, Ottawa, Canada. Seedling of Red June. Seed planted by former Horticulturist John Craig in 1895 .

Oyama: Form roundish to broad oval ; size medium ; cavity narrow, medium depth, abrupt; suture distinct line, not depressed ; apex rounded ; color deep red all over; dots obscure ; bloom thin, pale bluish; skin moderately thick, moderately tender, bitter; flesh yellow, firm, juicy; stone small, oval, cling; flavor sweet, not rich ; quality medium to above. Not specially promising. September 12,1904 . May be useful on account of hardiness of fruit buds. Hybrid group. Originated at Central Experimental Farm, Ottawa, Ontario. Seedling of Red June. Seed planted by former Horticulturist John Craig in 1895 .

Welcome: (Seedling of De Soto). Fruit above medium size too large, oval, flattened considerably ; cavity narrow, shallow ; color rich yellow more 
or less washed with red; dots very small, yellow, indistinct; bloom thin; skin moderately thick, fairly tough to rather tender; stone almost free; flesh yellow, juicy, sweet, a pleasant but not rich flavor ; quality good ; season mid September. A very handsome plum. Tree vigorous and productive. Americana. Tenderer in skin than most americanas. Originated at Central Experimental Farm, Ottawa, Canada.

Marketing. Less progress than could have been desired seems to be made from year to year in the marketing of plums. No package has secured recognition as being standard and no special methods of shipment have been worked out. In some sections fancy plums are marketed in quart baskets such as are used for strawberries. In other cases they are sent to market in six-basket peach carriers now largely used in Georgia. Climax grape baskets with bales are also used to some extent. There seems to be nothing but a matter of local convenience considered in selecting these packages. 


\section{CLASSIFICATION OF THE PEACH ACCORDING TO RACES}

\section{R. H. PRICE}

All cultivated fruits comprising a large number of varieties, are difficult to classify. This is true because of the well known fact that the tendency to vary is inherent. Under cultivation in widely different soils and climates, varieties with more or less variation are produced.

Any system of classification that is useful to the grower is of importance and is worth study. While however, some knowledge of a classification is necessary to the successful growing of a fruit over a wide area, and in different climates, a good system of classification is of very great importance to humanity. In a large measure I think this can be claimed for the classification of the peach herein outlined. Of course other systems of more or less value in distinguishing varieties have been devised and strange to say have held with pomologists till within the past few years. The system based upon the presence or absence of glands on the foliage enables one to distinguish a few varieties growing in the nursery; but some varieties bear different glands upon the same tree. Other points have value such as color of flesh, adherence or non-adherence of flesh to pits and size of bloom. All these points help to distinguish varieties but none of them has any phylogenetic importance. They have but little to do in enabling us to trace the relationship of varieties, the origin of varieties and the adaptability or non-adaptability of varieties to different thermal lines. Hence these systems appeal but little to the practical grower, or to the scientific horticulturist.

It is also true that an objection has been raised against the present system of classification in that all varieties could not be assigned to one or another of the five races. I might ask if this has been done with all the breeds (races) of horses, cattle, sheep and swine, where mixing and crossing have been carried on ad libitum for many years. If each animal cannot be assigned to one or the other of the various breeds owing to the mixture of different breeds in it, would any one venture the assertion that there are no true breeds of stock?

In regard to peaches, towever, it might be stated that if one has not studied the peach as it approaches its limit of successful culture near the tropics where many varieties, that are successful a thousand miles further north or on higher altitudes, utterly refuse to bear at all, the importance of this classification will be more difficult to appreciate at first. 



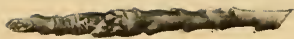

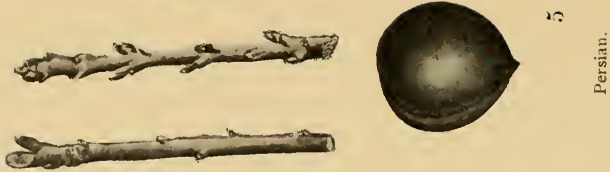

通
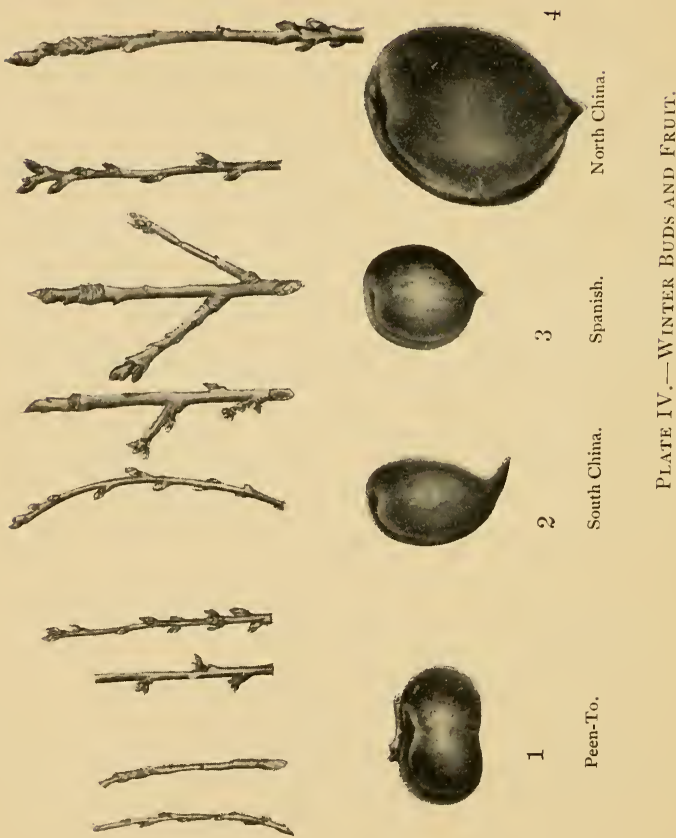


\section{Description of the Five Races}

In describing the races, I will begin with the one that comes farthest south and take them in order as they are adapted to different thermal lines as we go from the citrus belt north.

I Peen-to (Prunus persica, var platycarpa, Decaisne): Tree rather large, vigorous, branches willow-like, come out at an angle of about 40 degrees; flowers large, appear frequently in January in the states bordering on the Gulf, blooms at low temperature and very irregularly; winter buds, small, oblong, rather sharp pointed, grow close to the limb; leaves narrow, long, and inclined to hang on all winter; fruit much flattened ; skin white, mottled with carmine; flesh white, flavor sweet but has a peculiar almond taste ; seed nearly round, much compressed at the ends, corrugatious, small, somewhat round. This race takes its name from the variety "Peen-to", which is its ancestor. This variety was imported from Australia by Mr. P. J. Berckmans of Augusta, Ga., in 1869 , but its origin has been traced to China. This variety and some seedlings from it fruit well in northern part of the citrus belt. Some of its seedlings have fruited well in the southern part of California. Utterly worthless a few miles from the coast. Seedlings of Peen-to, however, fruit better farther north than the parent variety. Angel and Waldo are seedlings of Peen-to.

2 South China : The parent of this race is the variety Honey. The tree is a medium sized grower, branches come out at an angle of about 50 degrees and curve upward, less willow-like than Peen-to. Winter buds very prominent, round to oval, two or three buds often occur at the same place, occasionally projected axillary buds occur; buds occur on the limb all along to the top leaving no vacant places as we see in the "Persian" race. The dark red buds stand out from the limb at an angle of about 50 degrees ; leaves small, slightly trough-shaped, in the fall the color become slightly brownish red, foreshowing the color of the fruit in the young trees; hang on late in the fall; blossoms very large and profuse, very resistant to cold. A sure bearer in the Gulf States, requires short seasons of rest. Fruit rather small, slightly oval and a little flattened; suture very deep at base but only extends one-third the way down, apex long and recurved (see cut), has peculiar honey sweet flavor; seed is oval with apex slightly recurved, corrugations slight, prominent flange on one side. Honey, which is the parent of this race is supposed to have originated in Southern China hence the name of the race. Was imported from China by Chas. Downing in $185^{\circ}$, later was placed in the care of the late Henry Lyon of South Carolina where it fruited for the first time in America. Was introduced for the first time in America by P. J. Berckmans in $185^{8}$. Valuable American seedlings from Honey are Pallos, Climax, Coleman and Early China. 
3 SPAnish : Parent of this race is unknown but the type is supposed to have been brought over by the early Spanish settlers.

Tree is about the largest we have. The "Indian" type of this race has much "Persian" blood and these trees are not so large. Limbs large, long and spreading, inclined to droop down except in "Indian" type; buds, larger than those of South China and nearly always occur singly on the new wood, oval and project out from the wood at an angle of 50 degrees. Short naked places occur on the bearing wood, color of buds is dull grayish; leaves small, flat, hang on late in the fall, stay green during severe droughts, turn slightly yellow in the fall, foreshadowing the color of the fruit in a young tree; bloom often large and profuse. The fruit ripens very late, nearly always downy; color tinged with more or less yellow, nearly always acid and of low quality. The "Indian" type is usually streaked with red sometimes blood red under the skin. Seed oval, nearly flat, apex prominent, corrugations very large and wide; at the base they run more longitudinally than in any other race, flange often occurs on one side.

A heavy bearer and sure cropper in its proper zone. The "Persian " blood in the Indian type carries it well up into the central states. The seedlings one usually sees bearing such loads of small peaches along the fence and road sides most frequently belong to this race. This fact has led many amateur growers to believe that "seedling trees" are surer bearing trees than budded trees. The following are some varieties belonging to this race : Cobler, Columbia, Druid, Galveston, Guadalupe, La Reine, Lulu, Onderdonk, Sanders, Texas and Victoria.

4 North China: The parent of this race is Chinese Cling, which is supposed to have originated in North China.

Tree is a medium sized grower; bloom nearly always large; buds slightly larger than those of Spanish and more pointed, many latent buds occur near the tips of the limbs in the Gulf States especially, stand out at an angle of about 45 degrees; branches are short, thick and stubby. Leaves very large and flat, near fall in the Southern states especially, the foliage turns a peculiar dull pea green and by this characteristic alone one can easily recognize Chinese Cling and its seedlings in an orchard at once. Fruit the largest, dull white with small red blush on one side, ripens first on the outside, sometimes the skin may be easily stripped off by hand. Seed round, and irregular, somewhat more prominent on one side. It is by far the most important race known to the peach world. Such noted varieties as Elberta, Mamie Ross, and Carmen belong here. These go into the great markets of the north by the solid train load. Chinese Cling was imported by Chas. Downing and Mr. Henry Lyon of Columbia, D. C., was the first to fruit it in $185^{\circ}$. A second importation was made by William A. Spottswood of the U. S. Navy in 1860. From this later impor- 


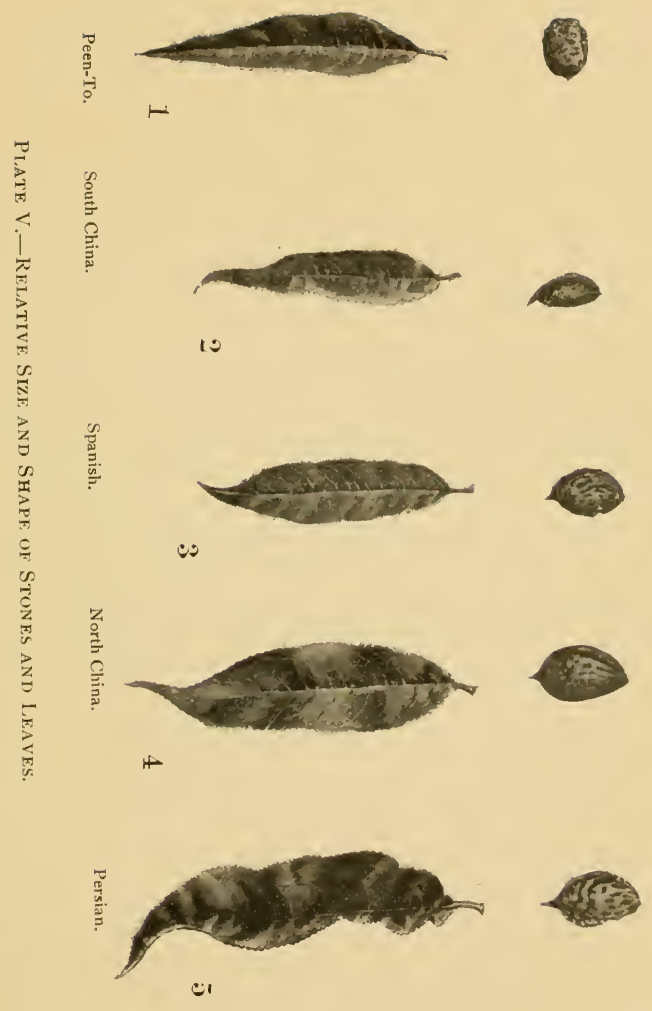



tation originated such varieties as Lee, Stonewall and Spottswood, some other varieties belonging to this race are:-Albert, Berenice, Becquett Free, Family Smock, and Thurber. The success of the noted Elberta variety which belongs here has enabled two growers to set the largest peach orchards in the south central states, known in the world.

5 Persian: The parent of this race is unknown but is supposed to have come from the high altitudes of Persia.

Tree medium size to large, limbs short and thick with long naked places, wood highly colored in the fall and winter, foreshowing a highly colored fruit; bloom varies in size; foliage nearly always crimped and conduplicate, has purplish tinge before falling off, sheds early, needs long period of rest; fruit most highly colored and of the best quality, stone more flattened at the base than any other, corrugations prominent at apex but seldom extend to the base as in Spanish (see cut). Well known varieties belonging to this race are: Alexander, Amsden, Amelia, Crawford, Downing, Golden Drop, Hale Early, Hynes, Mountain Rose, Old Mixon Cling, Old Mixon Free, St. John, Tillotson, Troth and Tuskena's. The bulk of northern orchards has come from this race. However, since such dreaded diseases as yellows and rosette have destroyed large orchards of the extreme northern states, the tendency of such growers now seem to be to go farther south where varieties of the North China race are adapted.

[Yellows in the north is not now the dread disease that was. Good sanitation holds it in check. SECY.]

The practical grower should not be so much concerned about what variety he should plant as about what race the variety belongs to which he wishes to plant. Herein lies the practical side of this classification. 


\title{
REPORT OF SPECIAL COMMITTEE ON GRAPES, FOR 1904
}

\author{
T. V. Munson, Denison, Tex., Chairman \\ Adaptation as to Solls
}

There are two classes of soils, requiring different varieties of grapes for each for best success, namely : very limy and very sandy soil. Those varieties of grapes cierived from species found naturally confined to sandy soils, possessing little lime, do poorly, (the foliage turning yellowchlorosis) when planted in very limy soils, such as the black waxy and adobe soils of the South (especially Texas) and California, when there is $5 \circ$ per cent or more of lime in the soil. To this class belong all pure varieties of labrusca, vulpina, (riparia), aestivalis, bicolor, and linsecomii of which some varieties of each are here mentioned.

Vitis labrusca: Champion, Columbian, Concord, Cottage, Uracut, Amber, Eaton, Hartford, Hayes, Ives, Jaynesville, Lutie, Martha, McPike, Moore Early, Perkins, Pocklington, Vergennes, Woodruff, Worden, Wyoming.

Vitis aestivalis: Norton's Virginia, (Syn. Cynthiana).

V. bicolor: Kohr and others named by Dr. G. L. Tinker, of New Philadelphia, O., upon which he is endeavoring to build up a new family of grapes for the North especially for wine purposes for which they are very promising.

V. vulpina: None of pure blood in cultivation, although Clinton and Taylor are commonly so classed.

V. linsecomii: H. Jaeger's No. 43 , Neosho, No. 13 , etc., of S. W. Mo., and T. V. Munson's No. I, Early Purple, Lucky, Big Berry, etc.

Likewise the hybrids of any two or more of the five species just named, of which a few are mentioned here do not succeed well in very limy soils.

Labrusca x vulpina: Amber, Bacchus, Clinton, Elvira, Etta, Grein's Golden, Marion, Missouri Riesling, Noah, Presly, Taylor.

Labrusca $\mathrm{x}$ aestivalis: Kentucky, a hybrid of Concord, with Norton; Gold Coin, a hybrid of Norton with Martha ; Ozark, a hybrid of Norton with Concord.

Linsecomii x labrusca: Beacon, Dr. Collyer, Mansleaf, and others.

Those varieties of grapes derived from species having their habitat in very limy soils, succeed well in soils having a high percentage of lime. The 


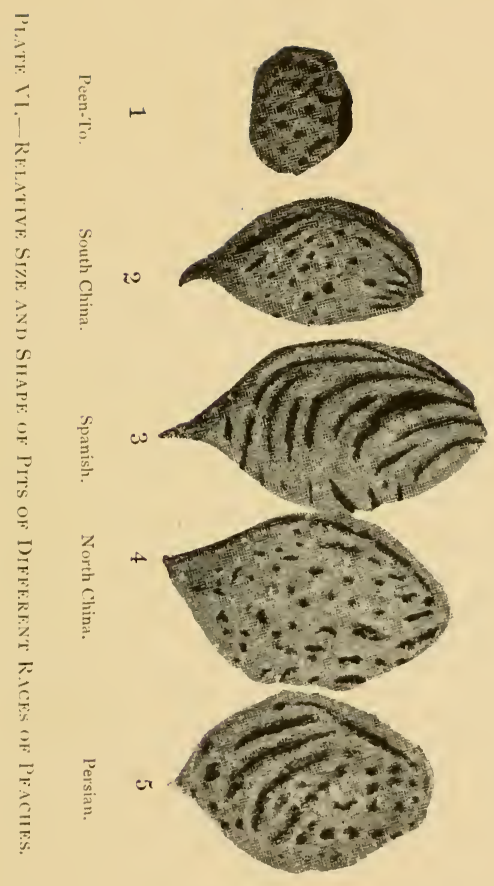



species from which these come are the Vinifera, Berlandieri, Bourquiniana, Candicans, Champini, Doaniana, and Rupestris. Some varieties are named.

$V$. Vinifera, an Asiastic species giving rise to the Muscats, Chasselas, Tokay, Malaga, etc.

$V$. Berlandieri, of S. W. Texas, has no pure varieties generally in cultivation, but has been hybridized with Vinifera to some extent.

$V$. Bourquiniana, furnishes the Cunningham, Devereux, Elsinburgh, Harwood, Herbemont, Lenoir, Louisiana, etc.

$V$. Candicans, the Texas Mustang grape has no pure varieties in cultivation. A hybrid of Elvira with it, - the Elvicand, grows well in quite limy soils, and a hybrid of Elvicand with Brilliant, flourishes in very limy soils.

I. Champini, native of Central Texas, is in cultivation in pure form only as a graft stock, on account of its success in limy adobe, droughty soils and to resist the Phylloxera, and the Anaheim Disease of California. It enters into the Lukfata, a hybrid with Moore Early, a grape equally good as Moore Early and succeeding in limy soils, also into the Champanel, a hybrid with Worden, likewise well adopted to moderately limy soils.

$V$. Doaniana, native of the Texas Pan Handle region. In cultivation only as a graft stock, possessing very similar qualities with Champini, but capable of enduring greater cold.

$V$. Rupestris, native of Texas, Ind. Ter., and Missouri in limy soils in the gravelly beds of small streams, where its roots can reach perpetual moisture. No pure varieties in cultivation, except as graft stocks. It enters into many hybrids in the $\mathrm{U}$ S. with $V$. Lincecumii, such as Jaegers No. 70 , and the America, Manito, Mericadel, Cloeta, Captain and others, all of which succeed well in moderately limy soil. The French have used it extensively as a stock in limy soils, and in numerous hybrids with Vinifera, both for direct producers of wine grapes, and for graft stocks.

All the species native in limy soils, succeed well also in sandy soils, and the hybrids among themselves, succeed well in both limy and sandy soils.

The hybrids between the species native of limy lands and those native of sandy lands are generally more capable of thriving in limy land than are the pure blood sandy land grapes, but much less successful in very limy lands, than the pure blood limy land varieties. We have examples among the Rogers Hybrids in Delaware, in Catawba (Labrusca x Vinifera) and many hybrids produced by the writer, such as Carman, Muench, Brilliant, Headlight, Wapanuka, etc. Some of these hybrids endure much more lime than others. Among Roger's Hybrids, the Goethe will endure as much as 50 per cent of carbonate of lime in the soil without chlorosing. So 
will Brilliant, which is a combination of Labrusca, Vinifera and Bourguiniana (the latter derived from Delaware).

All grapes require a well drained warm, porous soil, and one rich in potash. Stable manure is best fertilizer on heavy compact soils, and on light open soils a mixture of cotton seed meal, four parts and ground bone, one part, and from 600 to 1000 pounds of this mixture to an acre annually will keep the vineyard in vigorous condition.

\section{Adaptation as to Climate}

As it is with reference to soils, so it is with climate yet in a much more general degree, that varieties fail or flourish. Varieties developed out of a species native of a cold wet climate, taken to a dry hot climate, either perish quickly or linger along with indifferent success a few years and die out before or by the time they should be in their prime. We see this in varying degrees in all the Labrusca varieties and their hybrids with Vulpina (natives of Northeastern part of the United States) when planted in Texas west of the $97^{\text {th }}$ meridian (a hot dry climate).

The hybrids of Labrusca with Vinifera, succeed as well or better in Texas, than in New York, because Vinifera natively belongs to a hot dry climate. But the success is not nearly so great as hybrids of Vinifera Lincecumii or Champini.

The Concord and most other Labrusca varieties in Texas and other parts of the South, ripen unevenly, and reach their best state in 3 years, and in 8 or ro'years are on the decline, while the Bourquiniana, Linceiumii, Champini, Berlandieri, Doaniana and Rotundifolia varieties are in their glory for twenty-five to fifty years. But remove the last named varieties north of $38^{\circ}$ latitude and they either winterkill, do not ripen, or get sweet enough, as they take more heat to develop them than such climate furnishes.

There are some hybrids of Lincecumii with Labrusca and Labrusca $x$ Vinifera that succeed quite well as far north as $40^{\circ}$. Such are Beacon, Dr. Collier, R. W. Munson, which are reported as doing well in central Illinois and in New Jersey.

Strangely, the (Norton) Virginia so nearly allied to Lincecumii, when grown in Texas, is as short lived as Concord, and in some very dry seasons shrivels on the vine, while Lincecumii varieties, and hybrids with Norton, endure well and ripen perfectly. One is a native of the moist Virginia coast region, not far from Richmond, the other of the dry N. Texas region. Both are native in and love a very sandy soil.

The result of subjecting the various species to the attacks of the Anaheim Disease in California, is generally, that the varieties of American grapes which resist long, hot drouths best, also resist the Anaheim Disease best ; suggesting some connection of climatic hardship, such as drouth and heat, with the disease. 
By going more into detail, as to varieties, their derivations, and combinations, the report could be extended into the volume of a book, but it is thought enough is said to indicate general principals, so that any apt vineyardist, can deduce and readily apply correct practice in almost every case.

\section{T. V. Munson, Chairman of Com.}

Denison, Grayson Co., Texas,

Dec. I $4^{\text {th }}$, I 904 .

P. S. Along with my report I hand you the very valuable report of Mr. Geo. C. Husmann, another member of the Committee.

Owing to ill health, Prof. W. J. Green could not make a report, and no response has yet been received from Mr. A. H. Pettit, of Ontario, Can. T. V. M.

\section{NOTES ON ADAPTATION}

Prof. T. V. Munson,

Washington, D. C., Nov. 28,1904 .

Chairman Committee on Grapes, American Pomological Society, Denison, Texas.

Dear Mr. Munson :-

I have just returned from an extended trip of viticultural investigations to the Pacific Coast, and your letter of November $5^{\text {th }}$ addressed to me to the University of California, has been chasing me and has just caught me. Not knowing that a report was expected from me, it will be hasty and in the shape of a general letter.

That great differences exist in the adaptation of varieties to special soils and climates, latitudes and altitudes, there can be no question. Would mention a few striking instances. The Thompson seedless, which in the counties around San Francisco Bay, is a comparatively late ripening variety, has been grown in the Imperial regions near Coachello in southern California, as an early ripening variety. The Green Hungarian which my father and myself grew at Talcoa vineyards on adobe soil, near San Francisco Bay, produces fruit that was exceptionally fruity and heavy in saccharine, going as high as 26 and 28 degrees Balling saccharometer, and producing little or no second crop, whereas at my own place up in the mountains 30 miles from there at an elevation of 900 feet on gravelly loam, it produces enormous first and second crops and often a third crop, but in the best of seasons, never going above 23 degrees Balling, making a wine of Hock type.

Zinfandel the leading red wine grape of California, on hillside locations suited to it, makes a first class heavy bodied red wine, and on lowlands in the valley often not half a mile away from the former, only a vin 
ordinaire, a light colored, light bodied claret. Wines made from grapes in the Livermore district with age invariably develop Sauterne flavors, whilst the same varieties in the Napa and Sonoma districts partake of the Riesling character. Again, in the San Joachin and Sacramento valleys fine sweet wines and brandies are produced, whereas the dry wines in these valleys of the same varieties, as grown in the dry wine districts are always inferior.

Another instance, when the Phylloxera devastated the vineyards of Napa and Sonoma valleys in California, three kinds of resistant varieties were largely planted, namely, the Riparia, Rupestris and Lenoir. Now only a few of the Riparia plantings remain, and these are all of them good lasting vineyards within a radius of $\mathrm{I} 2$ miles from the Bay, where they are affected by fogs, etc. Farther inland they have succumbed on account of the spreading root system close to the surface. The Lenoir where the soil was deep so the roots could go down, have done well, whereas the Rupestris have done fairly well.

Last spring while out in California, I found at Livermore up to then the wild Riparia from Nebraska which had been largely used as a stock, had done well and many fine vineyards were to be seen grafted on it. This year has been an exceptionally dry and hot one, and this fall when I again visited that section, I did not meet with a single vineyardist who did not have a tale of woe to tell me regarding it. On the other hand, the vineyards on Rupestris St. George were doing quite well. At the Government experimental vineyard at Earleton, Florida, quite a number of Vinifera varieties were tried on resistant stock, and these resistants were either Riparia or Rupestris or crosses of the two. The first season that these were under my observation was a wet one, and the Riparia came out a little ahead. The next season was a dry one, and not only did the straight Riparias all go, but the crosses showed weaknesses accordingly, whereas the straight Rupestris stood it quite well.

The Scuppernong or Rotundifolia, regarding which the Department of Agriculture is starting investigations, does not to my knowledge extend farther North than Maryland. It flourishes along the coast and gradually disappears from the coast inland.

At Lewiston, Idaho, on a trip taken two years ago, I found quite good results had been obtained in growing Viniferas along the Snake River, most notably as to the Chasselas varieties (which I would say seem to have the happy faculty of adjusting themselves to quite a variety of conditions). A wine shown me by Mr. Robert Schleicher at Lewiston, Idaho, made from Viniferas grown there, would compare favorably with California product.

Would also state, in several parts of Oregon there is quite a tendency developing towards growing American varieties of grapes. In connection with this, it is interesting to note that European and American varieties are 
being grown successfully side by side in these vineyards. Quite a number of new varieties are under observation, but have not seen sufficient of them to make definite suggestions regarding them. Among these are some of your own varieties.

Of varieties sent out by the Department of Agriculture within recent years, two have shown up quite well, the Hungarian Millenium and Sultaniah Rosea.

Trusting this rambling letter may give you a few points of interest, and that you will let me know if I can be of further service.

Yours very truly,

Geo. C. Husmann, Viticulturist.

Member Committee on Grapes, American Pomological Society.

\section{REPORT OF COMMITTEE ON SMALL FRUITS}

Abel F. Stevens, Chairman, Wellesley, Mass.

Production of New Varieties: From my earliest years I have loved the production of New Seedling varieties of trees and plants for fruit, and the closer I am brought into communion with nature the more I am filled with gratitude to the Giver of all good-for that love for fruits and the enjoyment of the sweet intercourse with these beautiful objects of creation. We should look with wonder and admiration upon the infinite beauty and perfection of the works of the "Hand Divine" --the enamelled blossoms bespangling the orchards with starry spray-sweet harbingers of a beautiful harvest, the lucious fruits, "God's best gift to man." What pen can sketch the changing hues, the magnificence and glory when "Pomona" pours from her over-flowing lap the varied treasures of the ripening year? For a delicious, healthy, and nourishing food for our table let there be at all times and all seasons a most liberal supply of fresh fruits, for it is that source of food that is ever ready without cooking or special preparation for our tables.

\section{New Varieties}

Testing new fruits is an exceedingly interesting and very fascinating employment. If we happily find one new variety in our experiments, that gives promise of satisfactory paying results we are amply repaid for our time, expense and painstaking efforts, aside from the pleasure we have derived. We have devoted much time and expense to our experimental work in hybridizing and cross-breeding seedlings--both in the large as well as the small fruits, and know that the results of our labors have and will prove a blessing to the world. Let us do something in our day and gene1ation that will make the world brighter and better for as we now enjoy what others have planted, let us now plant that others may enjoy!

Specializing is now prevailing among the largest growers of fruits- 
the producer of yesterday has many varieties of different kinds but the grower of today selects only a few of the very best tested varieties, making a speciality of these and a grand success of his business.

Not for nearly a decade have small fruits been in such demand in all parts of the country as this past year. And the outlook was never better, for this business of growing choice fruits of the best quality, placed upon the market in the most attractive form, carefully graded, as to size, uniform in color, and ripeness, "honestly packed" in clean neatly stencilled packages and crates. A wise selection of best varieties-not only in quality-but in succession of ripening, so as to furnish a full supply to our patrons-these are the essentials of success.

Practical Notes: In the propagation of Currant and Gooseberry we always secure cuttings the previous fall when well mature for early spring setting, these we carefully label, tie in bunches of fifty each and dip the ends into melted grafting wax, or a mortar made of water and clay, then pack in damp sand or moss. Experience shows that a far better growth is made by all cuttings thus prepared than by leaving them to pass through the vicissitudes of winter. All of the bush varieties of small fruits that grow from cuttings always make better plants than the same varieties from layers, better root development, better for commercial and orchard purposes. The preparation of the cutting beds should be thorough and complete. Have the soil well pulverized and a liberal dressing of old stable manure to which we add $\frac{1}{5}$ part ground bone, well incorporated into the soil. During the growing season frequent cultivation with mulching between rows gives good winter protection to the hardy cuttings left in the cutting beds, but generally better results comes from storing all yearling cuttings in the storage cellars during winter-the terminal buds, so important, are thus secured by this practice.

Spraying: We have found that "Bordeaux" applied twice or three times in a season, sometimes in a more dilute form, and other times reenforced with Paris Green, or better still, Arsenate of Lead, has been very efficacious in controlling both mildew and leaf-blight on currants and gooseberries. Experiments on the worst forms of mildew treating with the following formula were tried:

I oz. of Potassium Sulphide

ro to 12 parts water.

A few sprayings of this mixture have been very successful in holding it in check and save both foliage and fruit.

To prevent the blighting of the foliage on Currants and Gooseberries, we found two early applications and one after the fruit had been gathered were sufficient. To prevent Black-1 ot which has been quite prevalent for several years, our best success has come from washing the vines in spring with a weak solution of Copper Sulphate using $\mathrm{r}_{3} \mathrm{oz}$. to $5 \circ$ gallons water 
-this in addition to the regular sprayings of Bordeaux. Even the dreaded "Anthracnose" has been controlled by this application.

In large plantations of raspberries we have found that the Black Cap varieties to be more affected than the red kinds. Our best treatment has been to keep the growing canes covered with Bordeaux and to cut out and burn old canes as soon as done fruiting.

For Blackberry " Rust" spraying with full strength Bordeaux and cutting clean and burning as soon as seen was the only remedy found efficacious.

Strawberries: Rustıng of the foliage of many varieties has caused great damage to paying crops. By keeping newly set beds well sprayed and dipping the plants in Bordeaux before planting; and in established beds spray before blossoming and after fruiting mow at once close and clean, scatter over beds old straw and burn all clean, then spray the new foliage with Bordeaux twice during the fall growth. The same treatment for leafspot will check and destroy the crown borer in our strawberry fields. A word of caution! Do not use any arsenious poisons on currants or gooseberries, blackberries, or strawberries, two weeks before picking the fruit.

For Scale Insects: Twenty parts of lime, I5 parts sulphur, Io parts sal-soda: Put 5 gallons hot water into a barrel, add lime, then sulphur, and lastly sal-soda. Stir until well slaked, add $5^{\circ}$ gallons water. When ready to apply is a red color with sediment. Draw off the wash and apply with spray pump.

This mixture has given me equally as good results as others made by boiling for hours.

Protection from Frosts: Late spring and early autumn frosts have caused immense amount of damage in the strawberry fields and vineyards. We have been very successful in combating the baneful effects of killing frosts by the following method :

Mix coal tar with sawdust and old straw, place in heaps about the fields on the windward side. When heavy frosts threaten set these heaps afire. They will burn for many hours making a dense smoke completely protecting the plants and vines heavily laden with blossoms and green fruit in the late spring and the partially ripened fruits in early fall.

Nut culture: In this important branch greatly increasing interest is being manifested in Northern and Eastern states. We find that the chestnut varieties and species lead, but the walnuts-both black and white-as well as the shell-bark hickory are receiving attention for the value of the timber of these species enhance the plantings. We have gathered black walnuts from trees seven years from seed. The sweet Spanish and Japan chestnuts are being tested largely here in the east. What the Pecan, Filbert and Alinond nuts are to the South and West, the improved chestnuts and walnuts are to.the North and East. These varieties are well worthy a place either for ornament or fruit. 


\section{VARiety Studies : Strawberries}

Gen. Warren: An extra early and extremely large, shapely berry, of superb quality, a vigorous grower and a productive plant. A seedling of of the famous Marshall and equal to it in size, color and quality and fully ten days earlier. We believe this new variety will command a premium for its extra high quality and loveliness, coupled with size and productiveness.

North Shore: A very strong late staminate variety that is very productive, of extra large bright colored berries of good quality. It has proved a grand pollinizer for our best Pistillate varieties, as Sample, Bubach and Haverland.

Commonwealth: Very large handsome crimson berry of extra quality, very productive, strong staminate and extremely late.

Howard's 4. A very promising seedling, vigorous plant, large conical berry, of good quality, productive and late.

\section{RASPBERRIES}

Cardinal: An extra large berry, of a bright red color, piquant acid flavor. The plant is a very large, strong grower. Cane, 8-12 ft., has proved to be very productive and profitable.

Herbert: For size, quality, productiveness, vigor, hardiness, great claims have been made and after a limited trial we are glad to say it seems to fulfill all of them.

Wellesley: The very best and largest extra early Black Cap grown. Superb in quality, very productive, vigorous and perfectly hardy. As the plants are very deep rooted and such vigorous growers it stands the drought better than any variety grown. Its wonderful productiveness and extra size and quality with handsome fruit that ripens with the earliest makes it in my opinion the most valuable Black Raspberry known to growers.

\section{Currants}

Steven's Superb: In this new variety we have the ideal currant. The plant is very vigorous, a rank grower, thick heavy foliage and excessively prolific, of long shouldered bunches with good neck for picking. Berries of the very largest of all known varieties, of a brilliant crimson color, very attractive on the table, or in the market baskets while the quality is certainly of the very best of all red varieties. This new seedling combines more excellent qualities than any one I have tried. 


\section{GooseberRies}

Golden Beauty : In this new seedling we have combined vigorous growth, healthy foliage, freedom from mildew, extra large, handsome berries of rich golden color and of fine quality, an excellent yellow gooseberry.

In the production of new varieties of choice fruits or fragrant flowers we all should be willing to contribute our share to the good of the cause for the laws of nature should be the secrets of none and he that has a knowledge of any important discovery in horticultural work should gladly impart it to others. The progress of all experiments should be noted down and this experience given to our associates for it is by the constant interchange of facts derived by experience that we owe much of our progress in horticulture. Let the cultivators of the soil give our art more attention and promote this interesting and benevolent employment. To our mind the production of delicious fruits and fragrant flowers carries the promise of a healthier race, of happier homes and a higher and nobler civilization.

The following report is by Mr. Matthew Crawford of Cuyahoga Falls, Ohio :

\section{THE NEWER STRAWBERRIES AND BUSH FRUITS}

\section{By M. Crawford, Ohio}

A good many new seedling strawberries are sent here on trial and the following are among the most promising :

\section{STRAWBERRIES}

Nehring's Gem : Originated in Missouri and not yet offered. The plant is very large and perfectly healthy and vigorous. It sends out many strong runners and will bear immense crops on old beds and still better on new ones. It is pistillate and commonly matures a berry for each blossom. The fruit is large, roundish, bright red, and of excellent flavor. It may remain on the plant for days after maturity without injury.

Victor, an Ohio berry. Plant, large, vigorous, healthy and productive. Fruit, very large, roundish conical, dark red, firm and excellent.

" Peck's 99 " from Missouri. Plant, large and healthy. Makes few runners, has a pistillate blossom and is fairly productive. The fruit is very large, roundish conical, the first specimens often triangular, but never misshapen. Color, deep red. Flesh, firm and very rich, delicious flavor. It will be well suited to hill culture as there will be few runners to cut.

Haymaker Raspberry: Found by Mr. Haymaker of Earlville, Portage Co., O. It is a purple variety of the Shaffer class, and probably the most productive of all raspberries. Here, in Northern Ohio, it is perfectly hardy. Where it is best known it is in great demand as a market berry. 
Compared with the Shaffer it is much more productive, of about the same color and quality but not as large. This variety has been grown extensively by C. S. Pratt of Reading, Mass., where it succeeds well.

Comet Currant: I imported this from England about seven years ago and have grown it with great satisfaction. It is a vigorous grower and a very prolific bearer. It is uniformly large in bunch and berry, of good red color, fine flavor and very attractive. Some of the fruit remained on the bushes in good condition until the first of October this year. Unlike the Versaillaise or the Fay it has no blind eyes and no unproductive plants.

Perfection Currant: I have seen only the fruit of this variety. It is very large in both bunch and berry, of good quality and fine looking.

\section{BLACKBERRIES}

Blower's: Found near Portland, Chautauqua Co.,N. Y., some fifteen years ago. It is an upright, vigorous grower, very hardy and enormously pro ductive. In 1903 I saw it bearing in four places and it was very fine everywhere. One man, who was not interested in its introduction, told me that it had not failed with him since it commenced to bear seven years before. A single plant produced over 2600 berries. It commences to ripen about the middle of July, and bears about two months. The fruit is very large and of good quality. A full crop was produced this year, and sold at $\$ 4.00$ a bushel and no other large variety in that locality produced a crop.

Kenoyer: Originated at Independence, Kansas. It fruited with me this year for the first time, but the robins took most of the berries. I had but four plants. It is an upright grower about four feet high and is thought to be a very desirable variety. The fruit is about the size of the Snyder. Those who know it best speak highly of its quality.

$\mathrm{La}$ Grange: This variety is said to have been brought from Russia. It is being grown to the extent of several acres at Potomac, Ill., by Chas. LaGrange, but has not been offered for sale. I have seen some branches of the fruit. It is a prolific bearer, of rather large size, fine looking and of good quality. One hundred berries made a quart.

Watt : This originated near Lawrence, Kansas, and is of very great promise. It is of large size, very superior quality, and has small seeds. Not yet offered.

In regard to new strawberries not yet offered, I reported on the Cardinal last year. After fruiting it on my own place this year, I would hardly care to change my report. 



